The Almacık mafic-ultramafic complex: exhumed Sakarya subcrustal mantle adjacent to the İstanbul Zone, NW Turkey

\begin{tabular}{|r|l|}
\hline Journal: & Geological Magazine \\
\hline Manuscript ID: & GEO-11-0787.R1 \\
\hline Manuscript Type: & Article \\
\hline Date Submitted by the Author: & 06-Jun-2012 \\
\hline Complete List of Authors: & $\begin{array}{l}\text { Bozkurt, Erdin; Middle East Technical University, Geological Engineering } \\
\text { Department; } \\
\text { Winchester, John; Keele University, Earth Science \& Geography, School of } \\
\text { Physical and Geographical Sciences } \\
\text { Satır, Muharrem; Universität Tübingen, Institut für Geowissenschaften } \\
\text { Crowley, Quentin; Trinity College, Department of Geology } \\
\text { Ottley, Christian; Durham University, Department of Geological Sciences }\end{array}$ \\
\hline Keywords: & $\begin{array}{l}\text { Almacık Complex, Sakarya Microcontinent, subcontinental mantle, } \\
\text { Palaeotethys, Jurassic metamorphism, Intra-Pontide ocean }\end{array}$ \\
\hline
\end{tabular}




\title{
The Almacık mafic-ultramafic complex: exhumed Sakarya subcrustal mantle adjacent to the İstanbul Zone, NW Turkey
}

\author{
ERDİN BOZKURT ${ }^{1}$, JOHN A. WINCHESTER ${ }^{2}$, MUHARREM SATIR $^{3}$, \\ QUENTIN G. CROWLEY ${ }^{4} \&$ CHRISTIAN J. OTTLEY ${ }^{5}$
}

\author{
${ }^{1}$ Middle East Technical University, Department of Geological Engineering, Üniversiteler \\ Mahallesi, Dumlupınar Bulvarı No: 1, Çankaya, TR-06800 Ankara, Turkey \\ ${ }^{2}$ Earth Science \& Geography, School of Physical and Geographical Sciences, \\ Keele University, Staffs ST5 5BG, UK \\ ${ }^{3}$ Institut für Geowissenschaften, Universität Tübingen, Wilhelmstrasse 56, \\ D-72074 Tübingen, Germany \\ ${ }^{4}$ Department of Geology, Trinity College, Dublin, Ireland \\ ${ }^{5}$ Department of Geological Sciences, South Road Durham DH1 3LE, UK
}

\begin{abstract}
The Almacik Mountains in northwestern Turkey expose an upper amphibolite facies complex consisting of alternating ultramafic (harzburgitic and websteritic) and mafic (metagabbroic) rock types. In the eastern part of this complex are island arc meta-tholeiites and transitional to calc-alkaline metabasites that are chemically quite similar to those of the Permo-Triassic Çele mafic complex north of Bolu, and this suggests an equivalence. However, much of the section exposes structurally deeper and chemically different mafic and ultramafic rocks, which have no equivalent in the Çele mafic complex, and isotopic dating has suggested that these rocks also formed during the Permian and underwent Triassic and Jurassic metamorphism. Furthermore, sparse inherited ages, unlike those from İstanbul Zone granitoids, suggest a link with North African-derived Armorican-type basement (and hence the Sakarya Zone), rather than Amazonia-derived Avalonian basement. Alternating mafic and ultramafic rocks suggest structural repetition, supported by the exposure of discrete highstrain zones or poorly-exposed shattered rock west of each outcrop of ultramafic rocks.

The high grade of metamorphism, and the absence of either extrusive lavas or sheeted dyke rocks suggests that the Almacik complex was not an ophiolite, but formed instead as subcontinental lower crust and subjacent mantle. Dominantly calc-alkaline geochemistry suggests that it formed the basement to an active continental margin bounding the north side of the Sakarya Microcontinent, with south-dipping subduction of Palaeotethys.

The Almacik complex was uplifted as a late result of compression against the southern margin of the İstanbul Zone in the Jurassic. Lack of coeval high-grade metamorphism in the İstanbul Zone indicates that the latter was overthrust southwards over the Sakarya margin, and that there was therefore a change of subduction polarity in the Triassic. The evidence further casts doubt on the existence of a Mesozoic Intra-Pontide Ocean in northwestern Turkey and the latest Permian magmatism, with subsequent Triassic and Jurassic metamorphism, were instead related to the closure of the Palaeotethyan Ocean.
\end{abstract}


Keywords: Almacik complex, Sakarya Microcontinent, subcontinental mantle, Jurassic metamorphism, Intra-Pontide ocean, Palaeotethys

\section{Introduction}

Northwest Turkey, comprising the western Pontides, is one of the key localities to study the tectonic evolution of the Palaeo- and Neo-tethyan oceans. It is a tectonic mosaic of, and was formed by the amalgamation of, several zones that comprise several continental slices and subduction-accretion complexes, including the Strandja Massif, the İstanbul Zone and the Sakarya Zone (Figs. $1 \& 2$ ).

The Strandja Massif in the west is the eastern continuation of the Rhodope and SerboMacedonian massifs in the southern Balkans and consists of a Palaeozoic basement and a Triassic-Jurassic cover sequence. It is alternatively interpreted as part of a Cimmerian continent (Şengör, 1984; Y1lmaz et al. 1997) or a Variscan fragment (A. Okay et al. 2001). The eastern contact with the İstanbul Zone is buried beneath the Eocene sediments (Figure 1) but is interpreted as a transform fault (A. Okay et al. 1994) or a suture (Y1lmaz et al. 1997). The Palaeozoic basement is composed of high-grade grade quartzo-feldspathic gneisses, migmatites, micaschists, orthogneisses and rare amphibolites and is intruded by early Permian (ca. 271-257 Ma) granitoids. The leucocratic, biotite-muscovite and hornblende-biotite orthogneisses yielded ca. 314-312 Ma Pb-Pb zircon ages; they are attributed to deformation and metamorphism during the Late Carboniferous or Early Permian (A. Okay et al. 2008). The cover rocks comprise a lower to middle Triassic-Jurassic sedimentary sequence of metaconglomerate, metasandstone, phyllite, calc-phyllite and marble (Aydın, 1988; A. Okay et al. 2001; Sunal et al. 2006, 2008, 2011; Natal'in, Sunal \& Toraman, 2005; Natal'in et al. 2012). The massif has suffered from a second phase of metamorphism at greenschist facies conditions during the Jurassic. Recent Jurassic to Cretaceous mica ages (162.9 to 118.7 Ma) are attributed to this phase, but their significance is interpreted differently. ${ }^{40} \mathrm{Ar} /{ }^{39} \mathrm{Ar}$ mica ages range from 156.5 to $142.6 \mathrm{Ma}$ and 136-118.7 Ma and are attributed to first mylonitic, then brittle deformation in the footwall of a detachment fault. In this model, the Strandja Massif is interpreted as a Late Jurassic-Early Cretaceous core complex (Elmas et al. 2011). $\mathrm{Rb}-\mathrm{Sr}$ muscovite ages range from $162.9 \pm 1.6 \mathrm{Ma}$ to $149.1 \pm 2.1 \mathrm{Ma}$ and are attributed to a regional greenschist- to lower amphibolite-facies metamorphism where peak conditions occurred at ca. $160 \mathrm{Ma}$. This event is attributed to north to north-east vergent ductile shear 
zones and brittle thrusts during a $\mathrm{N}$-vergent compressional deformation coupled with exhumation (Sunal et al. 2011). The massif is unconformably overlain by mid Cretaceous (Cenomanian) shallow marine sandstones.

The İstanbul Zone is a 400-km-long and 55-km-wide continental fragment along the southern margin of the Black Sea (Fig. 2) and is largely characterized by a thick ( $>3000 \mathrm{~m})$ little-deformed and largely unmetamorphosed passive margin-type Palaeozoic sedimentary sequence (known as the İstanbul Palaeozoic), extending virtually unbroken from the Ordovician to the Carboniferous (e.g. Abdüsselamoğlu, 1959; Haas, 1968; Görür et al. 1997; Y1lmaz et al. 1995, 1997; Dean et al. 2000; N. Okay et al. 2011; P.A. Ustaömer et al. 2011; Özgül, 2012 and references therein). Outcrops occur in the Kocaeli Peninsula (east of İstanbul), Armutlu Peninsula, Çamdağ, Almacık, Sünnice Mountains and Karadere area (Abdüsselamoğlu, 1959; Akartuna, 1968; Arpat et al. 1978; Y1lmaz et al. 1982, 1994; Cerit, 1990; P.A. Ustaömer 1999; Yiğitbaş, Elmas \& Yılmaz, 1999; Göncüoğlu et al. 2008) (Fig. 2). The Palaeozoic sequence commences with Ordovician basal conglomerates and sandstones unconformably overlying crystalline basement (e.g. Y1lmaz et al. 1982; P.A. Ustaömer \& Rogers, 1999; Yiğitbaş, Elmas \& Yılmaz, 1999; Yiğitbaş et al. 2004; Ustaömer, Mundil \& Renne, 2005.; Okay, Satır \& Siebel, 2006), exposed on the Armutlu Peninsula, and in the Sünnice Massif and Karadere area (Fig. 2). (i) In the Armutlu Peninsula, the basement is composed of high-grade amphibolite-gneiss sequence and intrusive Cadomian and MidOrdovician granitic rocks; granites suggest two periods of plutonism during the latest Proterozoic (570 Ma) and the Ordovician (460 Ma) (A. Okay et al. 2008). (ii) In the Sünnice Massif area, the basement is composed of a high-grade (amphibolite facies) metamorphic sequence dominated by migmatitic quartzo-feldspathic gneisses (Demirci paragneisses, Yiğitbaş, Winchester \& Ottley 2008), and a sequence of low-grade (greenschist facies) metavolcanics (Yellice lavas: meta-andesites and minor meta-rhyolites) (P.A. Ustaömer \& Rogers, 1999; Yiğitbaş et al. 2004). They are intruded by voluminous arc-related calcalkaline granitoids (Dirgine granite: Cerit, 1990; Erendil et al. 1991; P.A. Ustaömer \& Rogers, 1999; Yiğitbaş, Elmas \& Yılmaz, 1999; Yiğitbaş et al. 2004) which have yielded Ediacaran ages (565 \pm 2 and 576 $\pm 6 \mathrm{Ma}$; Ustaömer, Mundil \& Renne, 2005). The amphibolites of the Çele mafic complex, previously considered as the part of basement, are shown to be much younger, with late Permian to Triassic U-Pb zircon ages (Bozkurt et al. 2012). (iii) The basement in the Karadere area consists of a high-grade metasediments and metagranitoids. The metagranites suggest a continental arc setting and yielded zircon ages between 590 and $560 \mathrm{Ma}$ (Chen et al. 2002). The $\mathrm{Rb} / \mathrm{Sr}$ biotite ages are 548-545 Ma (Chen et al. 2002). The 
İstanbul Palaeozoic was deformed during a north to northeast vergent Carboniferous event (Zapc1, Akyüz \& Sunal, 2003) and was intruded by a Permian (ca. 255 Ma) granitoid (Y1lmaz, 1977). A Triassic continental to marginal marine sedimentary sequence covers the Palaeozoic succession with a marked regional unconformity. The eastern boundary of the İstanbul Zone with the Triassic-Early Jurassic Palaeotethyan oceanic assemblages (BallıdağKüre unit) in the central Pontides is a thrust (T. Ustaömer \& Robertson, 1993, 1994) while the southern boundary with the Sakarya Zone is at present marked by the active segments of the North Anatolian Fault Zone (Fig. 2). New zircon age data from both the basement and Palaeozoic sediments of the İstanbul Zone suggest that it is a peri-Gondwanan zone comparable to Avalonia (Bozkurt et al. 2008; A. Okay et al. 2008; N. Okay et al. 2011) or likewise originating close to Amazonia (P.A. Ustaömer et al. 2011). The İstanbul Zone was later detached from Avalonia, and then migrated to its present location by left-lateral strikeslip faults (Winchester et al. 2006; Bozkurt et al. 2008; N. Okay et al. 2011).

The Ballıdağ-Küre unit is a pre-Malm (Triassic-Early Jurassic) subduction-accretion complex, consisting of siliciclastic sediments, dismembered ophiolite, metabasics, mélange, and magmatic arc sequences (T. Ustaömer \& Robertson, 1994, 1997, 1999). The unit is cut by granitoids of mid-Jurassic age (Yılmaz, 1980; Boztuğ et al. 1984; Aydın et al. 1985, 1995; Y1lmaz \& Boztuğ, 1986). It is interpreted as a remnant of a back-arc basin (Küre), opened in the Early Triassic above a northward dipping Paleo-Tethyan subduction zone and then closed during the Late Jurassic southward subduction of the Palaeotethyan Ocean beneath the Sakarya Zone (T. Ustaömer \& Robertson, 1994, 1997, 1999; Kozur et al. 2000; Stampfli, 2000; Stampfli \& Borel, 2002; Robertson et al. 2004). The Ballıdağ-Küre unit was thrust onto the rocks of the İstanbul Zone before the late Jurassic, as upper Jurassic rocks form common cover.

The Sakarya Zone is an elongate crustal ribbon extending from the Biga Peninsula in the west to the Eastern Pontides in the east (Fig. 1). It is characterized by a crystalline basement and an unconformably overlying Lower Jurassic-Upper Cretaceous passive margin sedimentary sequence. The pre-Liassic crystalline basement comprises: (i) a high-grade (amphibolite to granulite facies) metamorphic sequence of gneiss, amphibolite, marble and scarce metaperidotite; the Variscan metamorphism is dated at 330-310 Ma (Carboniferous zircon and monazite ages; Topuz et al. 2004, 2007; A. Okay, Satır \& Siebel, 2006a; Nzegge $\&$ Satır, 2007). The high-grade metamorphic rocks occur in the Kazdağ, Devrekani, Pulur and Gümüşhane massifs (Fig. 1) and are intruded by Carboniferous granites (e.g., Topuz et al. 2010; P.A. Ustaömer, T. Ustaömer \& Robertson 2012). (ii) A Permo-Triassic low-grade 
Palaeo-Tethyan subduction-accretion complex, known as the Karakaya Complex, with Late Triassic blueschists and eclogites (Okay \& Monié, 1997; Okay et al. 2002). It is composed of metabasite with lesser amounts of marble and phyllite, accreted to the basement rocks during the latest Triassic (A. Okay \& Monié, 1997; Okay, Monod \& Monié, 2002; A. Okay \& Göncüoğlu, 2004; Topuz et al. 2004). These rocks are unconformably overlain by a Lower Jurassic-Lower Cretaceous transgressive sequence. Several different models have been proposed for the origin and evolution of the Karakaya Complex and the readers are referred to recent literature for further reading (e.g. A. Okay \& Göncüoğlu, 2004; Robertson \& T. Ustaömer, 2012; Sayıt \& Göncüoğlu, 2012).

The contact between the İstanbul Zone in the north and the Sakarya Zone in the south is interpreted as an ophiolitic suture zone, termed the Intra-Pontide Suture (Şengör, Yılmaz \& Ketin, 1980; Şengör \& Y1lmaz, 1981). It records the closure of a discrete early Jurassic to late Cretaceous-early Tertiary Intra-Pontide oceanic basin, one of the branches of northern Neotethys, which existed along the southern margin of Eurasia in the Pontides between the Rhodope-Pontide fragment in the north and the Sakarya Continent in the south (Şengör, Yılmaz \& Ketin, 1980; Şengör \& Y1lmaz, 1981). Because the NAFZ was superimposed on the supposed suture zone and there were no ages from the metamorphic and meta-ophiolitic rocks, the origin, age, evolution and even the existence of the Intra-Pontide ocean and its suture have been debated for decades. The proposed models fall into three groups: (1) The first model argued that several branches of the northern Neotethys existed and that the Mesozoic Intra-Pontide oceanic basin was one of them. It formed and later closed between the Eurasian continent (İstanbul Zone?) to the north and a microcontinent (Sakarya Continent) to the south within the western Pontides (e.g., Şengör \& Y1lmaz, 1981; Göncüoğlu \& Erendil, 1990; Y1lmaz, 1990; Y1lmaz et al. 1995, 1997; A. Okay et al. 1996, 2006; Göncüoğlu et al. 2008). There is however no consensus on the timing of opening (Early Jurassic: Şengör, Yılmaz \& Ketin, 1980; Şengör \& Y1lmaz, 1981; Late Bathonian: Göncüoğlu et al. 2008; Triassic: Robertson \& T. Ustaömer, 2004; Early Triassic: Akbayram, Okay \& Satır, 2012) and closure (juxtaposition of İstanbul Zone and Sakarya Zone) (Early Eocene-Oligocene: Görür \& Okay, 1996; Early Eocene: A. Okay et al. 1994; Paleocene-Lutetian: Şengör \& Y1lmaz, 1981; middle Late Cretaceous: Göncüoğlu et al. 2008; pre-Santonian: Özcan et al. 2012; Coniacian-Santonian: Yılmaz et al. 1995; Elmas \& Yiğitbaş 2001, 2005; Turonian: Robertson \& T. Ustaömer, 2004; Cenomanian: Tüysüz, 1999; pre-Cenomanian: Göncüoğlu \& Erendil, 1990; Early Cretaceous: Akbayram, Okay \& Satır, 2012) of the ocean. (2) The 
second model argues that there was only a single branch of northern Neotethys present and that the late Mesozoic (?) ophiolitic units in the region formed during the closure of the İzmirAnkara-Erzincan Neotethyan ocean, then were emplaced into their present position by leftlateral strike-slip faulting (Western Pontide Fault) during the Late Cretaceous (Elmas \& Yiğitbaş, 2001). This structure was interpreted as a transform fault in the İzmir-AnkaraErzincan Neotethyan ocean (Elmas \& Yiğitbaş, 2001). These authors termed the contact zone between the İstanbul and Sakarya zones the Armutlu-Ovacık zone. (3) The third model denies the existence of any Neotethyan (i.e. mainly Mesozoic) oceanic basin(s) in NW Turkey (e.g., Kaya, 1977; Kaya \& Kozur, 1987) and argues for Permo-Triassic and Late Jurassic-Early Cretaceous rifting events without seafloor spreading. This model considers supposedly ophiolitic rocks in the suture zone to be Precambrian in age.

The high-grade amphibolitic rocks in the Armutlu Peninsula and Almacık Mountains and a sedimentary mélange (Arkotdağ mélange: Tokay, 1973 or Abant complex: Y1lmaz et al. 1982) further in the east of Bolu are commonly used as supportive evidence for the existence of an Intra-Pontide ocean and its suture. In the Armutlu Peninsula metagranitoids intrude amphibolite-gneiss sequence and yielded latest Proterozoic (ca. $570 \mathrm{Ma}$ ) U-Pb zircon laser ablation MC-ICP-MS and Mid to Late Ordovician (460 Ma) Pb-Pb zircon evaporation ages (A. Okay et al. 2008). Aral Okay and his co-authors (2008) stated that 'the new isotopic data indicate unambiguously that the high-grade amphibolite-gneiss sequence in the Armutlu Peninsula is not of Cretaceous age but forms part of the late Proterozoic-Early Palaeozoic basement of the İstanbul Zone, as initially suggested by Kaya (1977), Yiğitbaş, Elmas \& Y1lmaz (1999) and Yiğitbaş et al. (2004). It is also suggested that the Intra-Pontide suture can be compared to Rheic suture (Stampfli \& Borel, 2002; Winchester and The PACE TMR Network Team, 2002; A. Okay et al. 2008).

The Arkotdağ mélange is a dismembered upper Cretaceous sedimentary mélange with blocks of pelagic limestone, radiolarian chert, pillow basalt, gabbro, clastic sediments, rare sheared serpentinite and ultramafic blocks within an intensely deformed, slightly metamorphosed matrix of debris flow deposits (Tokay, 1973; Y1lmaz et al. 1982). Göncüoğlu et al. (2008) studied a part of this tectonically disrupted complex and reported fossil assemblage from a single silicified mudstone sample from a block with alternating sediments and volcanic rocks (see their figure 3). Radiolaria yielded a late Kimmeridgian to early Tithonian age. The authors then argued, based on new data and previous fossil finds in the Çetmi mélange of the Biga Peninsula, that the Intra-Pontide ocean existed at least between the Bathonian and Santonian. However, it is not clear if the Arkotdağ mélange is part of a 
subduction-accretion complex of the Ankara-Erzincan Neotehyan ocean, as are upper Cretaceous HP-LT rocks in the central Pontides (cf. A. Okay et al. 2006b).

The high-grade ultramafic-mafic complex in the Almacik Mountains has long been, based on inferences and regional correlations, considered of Cretaceous age and is attributed to the Intra-Pontide suture (see next section). The region therefore forms a key locality to test alternative models on the existence and evolution of the Mesozoic Intra-Pontide ocean. In this paper, we report $\mathrm{U}-\mathrm{Pb}$ zircon age data from rocks of the Almac1k complex and discuss their tectonic significance. The paper also aims to test a possible similarity between Almacik and Çele complexes and discuss their tectonic significance.

\section{Almacık complex}

The Almacik complex is a tectonically-isolated block of mafic and ultramafic rocks set within the seismically-active North Anatolian Fault Zone in NW Turkey. All its exposed contacts with adjacent rocks are faulted. The dextral transcurrent North Anatolian Fault Zone (Figs. 2 \& 3) bounds the southern margin of the İstanbul Zone: it is exploiting the weakness of, and reactivating displacement along, the Triassic suture zone marking the contact between the İstanbul Zone in the north and the Sakarya Continent to the south (e.g. Elmas \& Yiğitbaş, 2001). Close to its southern margin, the basement of the İstanbul Zone is exposed as inliers of Proterozoic rocks, unconformably overlain by basal Ordovician conglomerates and sandstones (the largest inlier being the Sünnice Massif, north of Bolu; e.g., P.A. Ustaömer, 1999; P.A. Ustömer \& Roger, 1999; Yiğitbaş, Elmas \& Yılmaz, 1999; Yiğitbaş, Winchester $\&$ Ottley, 2008) (Fig. 1). This is in tectonic contact with the underlying Permo-Triassic Çele mafic complex (Bozkurt, Winchester \& Satır, 2012) in the Sünnice (Bolu) Mountains. To the southwest, in fault-bounded blocks within the North Anatolian Fault Zone, the structurally highest parts of a mafic-ultramafic complex exposed on the southern side of the Almacik range (Almacık complex) resemble the Çele mafic complex in the Sünnice (Bolu) Massif. Because of this apparent similarity, the rocks from the Almacik complex were sampled for geochemical analysis for comparison with those collected from the Sünnice area, interpreted as a meta-ophiolite (Yılmaz et al. 1995; Yiğitbaş, Elmas \& Yılmaz, 1999; Yiğitbaş et al. 2004), and termed by previous authors as the Çele meta-ophiolite (Yiğitbaş, Elmas \& Y1lmaz, 1999), but most recently considered to be basal crust to an active continental margin and thus renamed the Çele mafic complex (Bozkurt, Winchester \& Satır, 2012).

The Almacik complex is mainly composed of ultramafic and mafic rocks where all lithologies display tectonic contact relationships in an imbricate structure. The most 
characteristic lithologies include harzburgite, websteritic pyroxenite, locally carbonatized/listwaenitic harzburgite (local magnesite and some talc-magnesite occurrences), serpentinized harzburgite and websterite bands, serpentine-talc-epidote-spinel serpentinite, metagabbroic hornblende gneisses, isoclinally folded foliated amphibolites/metabasic rocks in the form of hornblende-plagioclase-quartz gneisses and hornblende-clinopyroxeneplagioclase gneisses and intruding plagiogranitic sheets. These rocks have experienced amphibolite facies metamorphism (at ca. $600-720^{\circ} \mathrm{C}$ and $5-\mathrm{kb}$; Çelik et al. 2009) and subsequent greenschist facies retrogression. The complex is in tectonic contact (thrust/reverse fault or strike-slip fault segments of the North Anatolian Fault Zone) with several different lithologies with ages ranging from Ordovician to Eocene (Fig. 3).

The ultramafic-mafic rocks were long considered to be late Cretaceous in age and were interpreted as the remnants of, and therefore the evidence for the existence of, a Mesozoic Intra-Pontide oceanic basin, a branch of northern Neotethys (e.g., Şengör \& Y1lmaz 1981; Yılmaz et al. 1982, 1995; Robertson \& T. Ustaömer 2004; Genç \& Tüysüz 2010). But as others claimed that these rocks may well be Neoproterozoic (Robertson \& T. Ustaömer 2004), Precambrian (Yiğitbaş, Elmas \& Yılmaz, 1999; Yiğitbaş et al. 2004; Elmas \& Yiğitbaş 2005) or Palaeozoic (Abdüsselamoğlu 1959; Gözübol 1980), these others argued for the existence of an Intra-Pontide ocean. Although the tectonic significance of the Almacik complex plays a key role in the Alpine history of the eastern Mediterranean area, the age assignments on the existing models were based largely on regional lithological and regional correlations and there has been no dating on these rocks. This paper therefore provides first geochronological data, discusses their tectonic significance and aims to comment on the existence and evolution of the Mesozoic Intra-Pontide ocean.

The Almacik complex is exceptionally well exposed for several kilometres along a recently constructed east-west section of the Mudurnu-Düzce highway and, owing to consistently steep dips and a local north-south strike, this section exposes a revealingly deep transect through the complex (Fig. 4).

\section{Petrography}

\section{3.a. Macroscopic and microscopic appearance}

Samples from the Almacik road section on the Mudurnu-Düzce highway display a great variety of textures and mineral assemblages. Sampling was greatly assisted by the blasting of the new road traversing the mafic-ultramafic complex from east to west, laying bare fresh new 
exposures in an almost continuous section. Throughout the section foliation dips tend to be steep, with a dominant north-northeasterly strike direction. Towards the west end of this section, ultramafic rocks become more abundant, suggesting that lower structural levels within the complex tend to occur in the west. From east to west, therefore, the road section appears to descend to progressively lower structural levels, although the presence of at least three distinct bands of ultramafic rocks with high strain zones on their western margins suggests that tectonic repetition as a result of ductile thrusting has also occurred (Fig. 2).

\section{3.b. Ultramafic rocks of the Almacik complex}

The main band of ultramafic rocks, which is at least $1 \mathrm{~km}$ thick, exposed at the western end of the Almacik road cutting, consists almost entirely of dark greenish harzburgite, which only shows minor evidence of hydration in the form of serpentinite and talc veining and local carbonatization, producing listwaenites containing pale magnesite. Away from the veining, and because of the relative lack of hydration, these harzburgites have suffered relatively little other chemical change during metamorphism and few secondary minerals are present, so the rock still contains dominant fresh olivine, with subordinate orthopyroxene and dark greenish spinel (Fig. 5a). A few grains of clinopyroxene are also present in some samples.

By contrast, the thinner ultramafic band approximately $1 \mathrm{~km}$ further to the east (Fig. 4), which is less than 600 metres wide, comprises rock that, although it has been extensively hydrated to a serpentine-talc-epidote-spinel serpentinite, has preserved textures which suggest that it too was originally harzburgitic.

The third, and easternmost ultramafic band, situated $1 \mathrm{~km}$ further east (Fig. 4), is a very distinctive green websteritic pyroxenite up to $1 \mathrm{~km}$ thick, devoid of olivine, but containing brown orthopyroxene and bright green clinopyroxene, probably chrome diopside (Fig. 5b, c). Usually medium-grained, these pyroxenites also contain a coarse-grained variant, with crystals that can exceed $4 \mathrm{~cm}$ across. This rock is well preserved and shows relatively little metamorphic replacement by amphibole, suggesting that very little subsequent hydration occurred.

\section{3.c. Mafic Rocks}

Varieties of hornblende gneiss of mostly mafic (gabbroic to gabbroic diorite) composition are the dominant lithologies, but display considerable textural variation. There is no textural evidence to suggest the former presence of deformed pillow-lavas: it therefore seems that, if this complex had been ophiolitic, like so many others in Turkey, its upper levels are not 
preserved. Medium- to fine-grained hornblende gneiss can locally have sharp contacts with coarser-grained metagabbroic hornblende gneiss: the contrast in grain size may reflect grain size variations in the igneous protolith, and hence the hornblende gneisses may include both gabbroic and former dyke (strictly metadoleritic) complexes. Variations also occur in mineral proportions: there are paler amphibolites containing a higher ratio of plagioclase to hornblende, and plagiogranitic sheets; the latter are locally garnetiferous and distinguished by intense deformation from pervasive later silicic intrusions of likely Jurassic age.

Between the main bands of ultramafic rocks are metabasic rocks, which petrologically resemble each other, but which can be separated into different suites chemically (see below). In the west, between the harzburgitic bands, metabasic rocks are typically hornblendeplagioclase-quartz gneisses, with accessory epidote and titanite, although in some the amphibole is unusually pale and may be actinolitic, occurring in association with abundant and well-developed crystals of clinozoisite. East of the websterite band, similar hornblende gneisses occur: in some of these the plagioclase is typically andesine and there are locally abundant grains of pyroxene displaying a symplectitic texture. These pyroxenes are not necessarily relict pyroxenes from the original mafic rocks: they are more likely to be products of metamorphism and to indicate that the complex underwent high amphibolite-facies metamorphism. Associated plagiogranite is composed dominantly of quartz and oligoclase, with very subordinate brown biotite, epidote and muscovite. K-feldspar appears to be absent.

By contrast, between the serpentinized harzburgite and websterite bands, the metabasic rocks seem in part to include veined and degraded pyroxenite, although their chemistry (see below) nonetheless tends to be basic, rather than ultrabasic.

Further east, around the small valley where a resthouse has recently been built, 'metabasites' tend to be paler. These rocks, which we term here the Resthouse metabasics, are also chemically distinctive (see below), and range in composition from basic to intermediate. They consist of hornblende-clinopyroxene-plagioclase gneisses, with scattered blades of secondary biotite, chlorite and muscovite betraying the presence of a late greenschist facies overprint, while more evolved rocks, of broadly dioritic composition, tend to be dominated by abundant andesine, with subordinate hornblende, biotite and accessory ilmenite and titanite. Many contain orange-red garnets, occurring as porphyroblasts up to one cm across. Secondary chloritization again suggests that, following the amphibolite facies metamorphism, these rocks were subjected to a superficial greenschist facies retrogression. Included in the Resthouse metabasics are rocks that are texturally metagabbroic or pegmatitic, with individual 
hornblende crystals growing up to eight $\mathrm{cm}$ in length. Garnet-bearing and strongly deformed plagiogranites are most abundant in this suite, and form a significant proportion of the rock.

The eastern part of the section consists entirely of more uniform hornblendeplagioclase-bearing mafic gneisses. These appear to form a distinct suite from the Resthouse metabasics, from which they are separated by a zone of sheared and mylonitized basic gneisses up to $100 \mathrm{~m}$ broad, showing that the contact is tectonic.

Overall, there appears to be a gradual increase in metamorphic grade towards the west, with amphibolite-facies hornblende gneisses grading progressively westwards into pyroxene granulites, in which the clinopyroxenes display symplectitic textures and have only been partially hydrated to hornblende. However, the westernmost mafic gneisses show a return to amphibolite-facies assemblages.

Prominent features along the entire road section are discordant mafic and granitoid dykes which crosscut the foliation and show little evidence of amphibolite facies metamorphism. Most of these probably relate to Jurassic or later magmatism in the area.

Within the complex, no textural evidence to suggest the former presence of either a sheeted dyke complex or pillowed basalts was observed: it is therefore concluded that the hornblende gneisses are likely to be almost entirely derived from the metamorphism of intrusive gabbros. Indeed, it is questionable whether the Almackk complex is uplifted ophiolite at all: in view of its high metamorphic grade it is possible that it represents a wedge of continental basement and subjacent mantle, and the absence of sheeted dykes or pillowed metabasalts is not simply a result of current erosion levels.

\section{Chemical discrimination}

Representative analyses are shown on Tables 1 and 2. Only the fresher samples were selected and they were also chosen as typical of the common lithologies present. The samples were crushed at the Middle East Technical University, Ankara and analysed at Keele University, England, using an ARL 8420 X-ray fluorescence spectrometer, calibrated against both international and internal Keele standards of suitable composition (Floyd \& Castillo, 1992). Analytical methods and precision are detailed in Winchester, van Staal \& Langton (1992). Selected samples were also analysed for rare earth elements together with Cs, Hf, Sc, Ta and U, using a PE Sciex Elan 6000 inductively-coupled plasma mass spectrometer (ICP-MS) at Durham University. More accurate determinations for $\mathrm{Nb}$ and $\mathrm{Th}$ in these samples were also obtained by this method and full analyses are provided in Tables 1 and 2. Data previously 
published (Yiğitbaş et al. 2004) are also plotted on some of the succeeding diagrams, as the distribution of those samples complements those collected for this study.

\section{4.a. Ultramafic rocks}

The ultramafic rocks cropping out along the Almacık road cutting fall into two clearly divided compositional sets (Table 1). Along this section the three bands of ultramafic rocks, thought to represent structural repetitions of the deepest part of the complex, show compositional characteristics that enable them to be chemically discriminated. Sampled for this study were harzburgites, serpentinized harzburgite, and pyroxenites (websterites). Apart from predictably enhanced Loss on Ignition and $\mathrm{Cl}$, and loss of $\mathrm{CaO}, \mathrm{Cr}$ and $\mathrm{V}$ (Table 2), the composition of the band of serpentinized harzburgite is similar to that of the fresh harzburgite.

However, the websterites are compositionally distinct in having significantly less $\mathrm{Fe}_{2} \mathrm{O}_{3}$ (total), $\mathrm{MgO}$ or $\mathrm{Ni}$ and enhanced $\mathrm{SiO}_{2}, \mathrm{CaO}, \mathrm{Cu}, \mathrm{Sr}, \mathrm{Y}$ and $\mathrm{V}$ compared to the harzburgites. The harzburgites (including the serpentinized sample), characterized by very high $\mathrm{MgO}(>35 \%)$ and Ni contents (Fig. 6a-c), plot entirely separately from the websterites, which have characteristically much higher $\mathrm{CaO}$ and lower $\mathrm{MgO}$ than the harzburgites. Both rock-types have exceptionally high $\mathrm{Cr}$. The websterites are characteristically much richer in REE than the harzburgites, and display a broadly level, slightly convex-up profile, lacking a significant Eu anomaly (Fig. 6d).

\section{4.b. Mafic to intermediate rocks}

The distribution of the chemically distinguished metabasic and meta-ultrabasic rocks along the Almacik road section is shown, together with locations from which samples were obtained, on Figure 4. Chemical contrasts between the mafic rock-types are less clearly defined than in the Çele mafic complex, as most of the rocks cluster on the margin between the tholeiitic and calc-alkaline fields, and so a ternary AFM diagram only reveals a rather indistinct calc-alkaline trend in these rocks (Fig. 7a). However, a few evolved meta-dioritic samples, associated with metagabbros, appear to have a calc-alkaline protolith. These rocks tend to occur around the most deeply incised valley descending from the Almacik mountains along the road section, and crop out close to the newly built Resthouse in the valley. Referred to here as the Resthouse metabasics, they include the palest and most highly deformed, often garnetiferous gneisses, associated with the best developed plagiogranites. In summary, it was possible to recognize four chemically-distinguishable metabasite suites in the Almacik 
section, which we have termed: (i) Western metabasites, (ii) Akçalaan metabasites, (iii) Resthouse metabasites, and (iv) Eastern tholeiites.

Other discrimination diagrams highlight minor compositional differences, notably variations in the proportions of $\mathrm{Sr}$ to $\mathrm{Y}$ and between $\mathrm{Zr}, \mathrm{TiO}_{2}, \mathrm{Fe}_{2} \mathrm{O}_{3}$ (total) and $\mathrm{Cr}$ (Fig. 7c, d), that seem to distinguish between these suites of mafic gneisses and help separate them into geographically discrete blocks.

On a V-Ti plot (Fig. 7b) to distinguish island arc tholeiites from other oceanic basalts (Shervais, 1982), only the rocks from the easternmost end of the section (Eastern tholeiites), together with a single sample collected from the metabasites sandwiched between serpentinite and websterite close to Akçalaan Yurse village (termed here the Akçalaan metabasite) cluster consistently within the island arc tholeiite field (Fig. 7b). Eastern tholeiites, distinguished by separate ornament on Figures 7 and 8, consistently form a discrete cluster of points. However, they share high $\mathrm{Y} / \mathrm{Sr}$ with the mafic gneisses (western metabasites) obtained from the western part of the section between the two harzburgite bands and from immediately east of the websterite band. These gneisses differ from the Eastern tholeiites principally because they contain lower $\mathrm{V} / \mathrm{Zr}$, and tend to form a separate trend on a $\mathrm{Cr} / \mathrm{Fe}_{2} \mathrm{O}_{3}$ (total)-Sr/Y diagram (Fig. $7 \mathrm{c}, \mathrm{d})$. The Resthouse metabasites can be distinguished from the other mafic suites by virtue of their lower $\mathrm{Y} / \mathrm{Sr}$ on $\mathrm{V} / \mathrm{Zr}-\mathrm{Y} / \mathrm{Sr}$ and $\mathrm{Cr} / \mathrm{Fe}_{2} \mathrm{O}_{3}$ (total)-Sr/Y diagrams (Fig. 7c, d).

A chondrite-normalized REE profile shows little distinction between the Eastern tholeiites and the Western metabasites. Both have broadly flat profiles, comparable enrichment and lack a $\mathrm{Eu}$ anomaly (Fig. 8a). By contrast, the sample from the Resthouse metabasites, obtained from pegmatitic hornblende gneiss near the resthouse, shows a sloping profile with LREE enrichment, while the sample from the Akçalaan metabasite shows a marked LREE depletion.

MORB-normalized multi-element profiles typically show a spiked and sloping profile, which is most marked in the Resthouse (enriched) and Akçalaan (depleted) metabasite profiles (Fig. 6b). By contrast the other metabasite types show more subdued profiles, but still display $\mathrm{Nb}$-Ta and Hf troughs, and $\mathrm{Ba}, \mathrm{Ce}$ and Sm peaks. Only a single Western metabasite profile resembled those of the Çele calc-alkaline metabasics in lacking a $\mathrm{Nb}$-Ta trough, and this lack of chemical comparability confirms that there is no exact match of metabasite types between the Çele mafic complex and the Almacık complex. 


\section{4.c. Comparisons between the Çele mafic complex and the Almacık complex}

Comparisons between the Almacik complex and the Çele mafic complex show that, while there are similarities, the match is imprecise. For example, the Çele mafic complex does not expose the range of ultramafic rock types displayed in the Almacik section, although the analyses of its serpentinites vary between meta-harzburgite to meta-troctolite, suggesting a limited range of compositions. However, in both areas metabasites with an island arc tholeiite chemistry seem to occur at the highest structural level, and are underlain by suites of calcalkaline metabasite. The distribution of the ultramafic rocks is potentially more problematic, but the locations of broad exposed shear zones along the Almacik road section shows that they are restricted to the basal portions of discrete thrust slices, and this segregation into different thrust slices might also explain their diversity, as they were probably juxtaposed after transport from different parts of the original complex.

\section{Isotopic dating}

Sampling was focused on the rocks exposed along the Almacik road section. Three samples (60-I, 61-I and 65) from locations 60, 61 in the Resthouse metabasites and 65 in the Eastern tholeiites) were selected from the plagiogranite dykes intruding the metabasic rocks (Figs 4, 9). It is possible that some zircons in the plagiogranites may be xenocrystic. In all samples, quartz and oligoclase form the main component minerals, while brown biotite, epidote and muscovite are subordinate grains. Details of mineral separation methods and analysis techniques are given in Okay et al. (2008).

Several zircons were separated from sample 60-I; they occur as mostly small grains but are uniform in size $(125-180 \mu \mathrm{m})$. The grains are clear idiomorphic, bi-pyramidal, medium-thick, stumpy or long and xenomorphic-prismatic to rounded, colourless, and almost free of inclusions. Thirteen grains analysed at Tübingen yielded a bimodal distribution

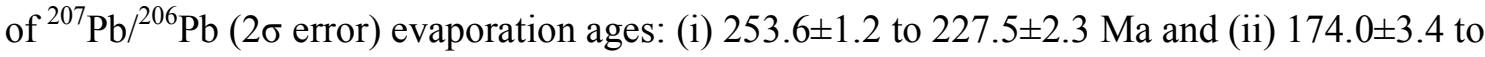
166.7 $\pm 2.8 \mathrm{Ma}$ (Table 3). Further studies of the older ages revealed four groups with mean ages of: (i) $253.6 \pm 2.6 \mathrm{Ma}$ (ii) $242.7 \pm 2.4 \mathrm{Ma}$, (iii) $235.7 \pm 2.7 \mathrm{Ma}$ and (iv) $227.5 \pm 3.3 \mathrm{Ma}$ (Fig. 10a). The same sample was also analysed using laser ablation multicollector inductively coupled plasma mass spectrometry (LA-MC-ICP-MS) at NIGL. 70 zircon grains were analysed from this sample; the morphology of big zircon grains suggests that they had metamorphic overgrowths. Because the zircon 'cores' were quite uranium-depleted, a large laser spot size (50 microns) was used to get a decent signal. These 'cores' have produced a U$\mathrm{Pb}$ concordia age of $255.3 \pm 1.5 \mathrm{Ma}$ (Table 4, Fig. 10b). The 'rims' were much more uranium- 
rich and gave a $\mathrm{U}-\mathrm{Pb}$ concordia age of $167.1 \pm 2.1 \mathrm{Ma}$ age (Fig. 10b). The important point to make here is that $\mathrm{Pb}-\mathrm{Pb}$ single zircon evaporation and LA-MC-ICP-MS methods all yield similar ages of ca. $250 \mathrm{Ma}$. A Rb-Sr biotite age was also obtained from this sample at Tübingen. The biotite contains $209.4 \mathrm{ppm} \mathrm{Rb}$ and $28.28 \mathrm{ppm} \mathrm{Sr}$; the ${ }^{87} \mathrm{Sr} /{ }^{86} \mathrm{Sr}$ and ${ }^{87} \mathrm{Rb} /{ }^{86} \mathrm{Sr}$ ratios are $0.748335 \pm 08$ and 21.516 , respectively. The biotite yields an age of $139 \pm 2 \mathrm{Ma}$ (Table 5). Garnets were separated from the granitic rock and based on $\mathrm{Sm}-\mathrm{Nd}(2 \sigma)$ analysis at Tübingen they yielded an age of $172 \pm 41 \mathrm{Ma}$. The garnet data is consistent with the younger ages from the rims of the zircons. Although the error is too high in this data, it apparently shows garnet growth during metamorphism at ca. $170 \mathrm{Ma}$.

Nine zircons analysed from sample 61-I at Tübingen are mostly small grains, uniform in size $(125-180 \mu \mathrm{m})$, clear, long and slender, xenomorphic to prismatic, colourless, and almost free of inclusions. The analysed zircon grains yielded a wide distribution of ${ }^{207} \mathrm{~Pb} /{ }^{206} \mathrm{~Pb}$ ( $2 \sigma$ error) evaporation ages, varying between $256.0 \pm 5.2$ and 160.7 $\pm 4.8 \mathrm{Ma}$ (Table 3 ). The age data fall into four groups: (i) $256 \pm 5.2 \mathrm{Ma}$, (ii) $245.5 \pm 2.6 \mathrm{Ma}$, (iii) $216.6 \pm 4.1$ (mean age) and (iv) $162.9 \pm 2.6$ (mean age) (Fig. 10c, d). Four titanite grains from the sample sample were also analysed at Tübingen (Table 6). The distribution of titanite ages along a discordia line shows a lower intercept of $163 \pm 20 \mathrm{Ma}(\mathrm{MSWD}=2.2)$ but with no useful upper intercept (Fig. 10e).

Zircons from sample 65 are mostly small grains, uniform in size $(125-180 \mu \mathrm{m})$, clear, medium, long and slender, prismatic, colourless, and almost free of inclusions. The zircon grains analysed at Tübingen yielded a wide distribution of ${ }^{207} \mathrm{~Pb} /{ }^{206} \mathrm{~Pb}(2 \sigma$ error) evaporation ages, varying between $2442.6 \pm 2.8$ and 281.0 \pm 3.9 Ma (Table 3, Fig. 10f).

As seen from the information above, reliable dates from the zircons yield Permo-Triassic dates of 255, 235 and $227 \mathrm{Ma}$, and Jurassic ages, ranging between 170 and $162 \mathrm{Ma}$. The ca. $140 \mathrm{Ma}$ biotite $\mathrm{Rb}$-Sr ages reflect cooling below $400^{\circ} \mathrm{C}$ conditions. These we interpret as the Permian and Triassic ages of original rock formation (crystallization) and its subsequent Jurassic metamorphism and cooling, respectively. Plagiogranites (cf. Thayer, 1977) commonly occur as late intrusions into the gabbroic section of oceanic crust (e.g. Aumento, 1969; Casey, 1997; Silantyev, 1998; Dick et al. 2002) and/or into the plutonic sections of most ophiolites (see Koepke et al. 2004). They are therefore commonly used to date the crystallization age of ophiolitic rocks and examples of such case are documented in areas from Balkans through Anatolia to Oman (e.g. Tilton, Hopson \& Wright, 1981; Mukassa \& Ludden, 1987; Liati, Gebauer \& Fanning, 2004; Warren et al. 2005; Konstantinou, Wirth \& Vervoort, 2007; Dilek \& Thy, 2006, 2009; Dilek, Furnes \& Shallo, 2008; Karaoğlan et al. 
2012). The Permo-Triassic age for the Almacik complex is further supported by new geochronologic data from their likely equivalent Çele mafic complex in the Sünnice Massif (Bozkurt et al. 2012) where both the metabasics and intrusive granites yield Permo-Triassic ages. Inherited zircon ${ }^{207} \mathrm{~Pb}^{206} \mathrm{~Pb}$ ages cluster at $431 \mathrm{Ma}$ (Silurian), $1660 \mathrm{Ma}$ (Mesoproterozoic), and $2400 \mathrm{Ma}$ (Palaeoproterozoic). Because ${ }^{207} \mathrm{~Pb}-{ }^{206} \mathrm{~Pb}$ ages record older evolution of the zircons, they suggest that such zircons may be xenocrystic in the plagiogranites, and as such may indicate the age of source rocks as well as the history of zircons prior to the major Permian event.

\section{Discussion}

\section{6.a. Structural considerations}

The Almacik section exposes mafic and ultramafic rocks disposed in at least four thrust slices, now tilted so that they are mostly steeply dipping with their structural tops towards the east. Hornblende gneisses with island arc tholeiite chemistry occur at the structural top of the sequence (Eastern tholeiites), confined to a discrete uppermost nappe. A broad ductile shear zone, well-exposed on the Almacik road section, separates it from the underlying nappe containing multiply deformed hornblende gneisses with a broadly calc-alkaline chemistry (Resthouse metabasites). The Resthouse metabasites may form part of the same thrust slice as the underlying, more tholeiitic hornblende gneisses (Western metabasites), with thick, wellpreserved ultramafic websterites at the base. Beneath these is another broad (but very poorly exposed) ductile shear zone that marks the contact with a third thrust slice comprising the Akçalaan metabasites overlying an ultramafic base, which here consists of serpentinized harzburgite. An underlying fourth and lowest thrust sheet again consists of tholeiitic hornblende gneisses (Western metabasites) overlying a much thicker ultramafic base comprising fresh harzburgite and subordinate lherzolite. These rocks are faulted against pelitic schists of unknown age to the west, so the base of the complex is not exposed on the road section.

Neither the components, nor the sequence of rocks in these thrust sheets match each other precisely, and there is no evidence of an exact repetition of the sequence by means of folding. It therefore seems likely that different parts of the same Almacik complex were juxtaposed by ductile thrusting at the time of its collision with the southern margin of the İstanbul Zone. 
In this model the distribution of the ultramafic rocks merits comment. Whereas harzburgite, possibly representing depleted mantle, dominates in the lower parts of the lower nappes, websterite, perhaps representing undepleted mantle, seems to be confined to an overlying nappe only. It is tempting to speculate that the depleted mantle was formerly situated beneath a back-arc (or back-ACM) basin spreading centre where mantle depletion could result from repeated magmatic activity, but other causes could equally be cited. The surviving evidence is simply insufficient for a conclusion to be reached.

The Almac1k complex contains no preserved pillow lavas, cherts, or other typical oceanic sediments. This suggests that most of the preserved rocks are derived from the lower part of the crust: layered gabbros and diorites and subjacent mantle are present, whereas the sheeted dykes, suboceanic lavas and overlying sediments usually present in an ophiolite are absent. This suggests instead that these Permian metabasic rocks, with their Jurassic high metamorphic grade, may represent the lower crust of the Sakarya Continent. The presence of a significant proportion of metadioritic gneisses (the Resthouse gneisses) also suggests that these rocks may have formed in a subcontinental, probably sub-ACM setting, rather than an oceanic one and this ACM was probably formed on the northern supra-subductional margin of the Sakarya Continent.

\section{6.b. Regional significance of the evidence that the Almaclk rocks were Sakarya basement}

North Africa-derived Variscide blocks (often referred to as 'Armorican' in Europe) contain zircons dominantly recording a Palaeoproterozoic inheritance with ages ranging from 2.4 to $1.9 \mathrm{Ga}$, a few scattered outcrops of gneiss of similar age, such as the Icart gneiss of Guernsey, and a scattering of Archaean ages ranging back to $2.7 \mathrm{Ga}$. There is an almost total absence of Mesoproterozoic ('Rondonian') inherited dates similar to those in Avalonian Zones (Samson et al. 2005) such as the İstanbul Zone (Winchester et al. 2006; Bozkurt et al. 2008; A. Okay et al. 2008), and this suggests instead a source in the West African craton, in which the 2.2-1.9 Ga Eburnean belt comprises both Palaeoproterozoic juvenile crust and reworked Archaean rocks up to $2.7 \mathrm{Ga}$ old probably derived from the Reguibat Craton in Mauretania (Schofield et al. 2006). These blocks did not need to travel as far as those comprising Avalonia, and the Proterozoic basements of Carolina and Iberia may thus have originated from a section of the Cadomian arc which was not distant from that which later became the İstanbul Zone. They may also have included the Sakarya Continent of northwestern Turkey. 
The significance of the Silurian date is currently unknown, while neither of the Proterozoic dates correspond to the Rondonian mid-Proterozoic inherited dates, so characteristic of Avalonia and its likely extension in the İstanbul Zone (Winchester et al. 2006; Bozkurt et al. 2008; A. Okay et al. 2008; N. Okay et al. 2011; P.A. Ustaömer et al. 2011). This suggests that any original basement which might have contributed to the Permo-Triassic melts that congealed to form the gabbros of the Almacik complex was not related to the İstanbul Zone. Instead, its inherited age range is more like those of the North African-derived Armorican Zones seen in Europe, as elegantly illustrated by Samson et al. (2005). In Turkey, this suggests that the Almacik complex is more likely to be related to the Sakarya Continent to the south. This in turn suggests that these late Permian rocks were intruded on the southern side of the Palaeotethys Ocean, prior to its closure in the Triassic (cf. Şengör, Y1lmaz \& Ketin, 1980; Şengör \& Y1lmaz, 1981; Şengör, 1987; Robertson et al. 1996; A. Okay \& Monié, 1997; Yiğitbaş, Elmas \& Y1lmaz, 1999; A. Okay, 2000, 2008; Stampfli, 2000; A. Okay, Monod \& Monié, 2002; Stampfli \& Borel, 2002; A. Okay \& Göncüoğlu, 2004; Robertson \& Ustaömer, 2004; A. Okay, Satır \& Siebel, 2006; Moix et al. 2008), with the collision of the Sakarya Continent and İstanbul Zone.

\section{6.c. Comparison with the Çele mafic Complex}

The upper two tectonic slices of the Almacik complex have a chemistry more like, but not precisely equivalent to, the two tectonic slices exposed in the Çele mafic complex, which was itself tectonically underthrust beneath the base of the İstanbul Zone (Bozkurt, Winchester \& Satır, 2012). Isotopic dating in both complexes has shown them to be of similar age, and it is therefore highly likely that they are parts of the same mafic complex which has been tectonically dismembered, largely as a result of recent movement along the North Anatolian Fault Zone. However, the lower parts of the Almacik complex contain much more ultramafic rock than is exposed in the Çele mafic complex, in which the lower nappes are not currently exposed. Both complexes may thus be interpreted as parts of the lower crust and subcontinental mantle of an ACM fringing the Sakarya Continent, and the İstanbul Zone basal thrust may thus represent the Rheic Suture in northwest Turkey.

\section{6.d. Tectonic significance of Jurassic metamorphism and magmatism}

Late Middle Jurassic (ca. 170-162 Ma) U-Pb zircon and titanite and Sm-Nd garnet ages record high temperature metamorphism associated with over-thickening of crust, before its incipient break-up and initiation of extension. This is consistent with late Middle Jurassic 
magmatism, producing both S-type granites (ca. 165 Ma plutonism, see figure 7 in Yiğitbaş, Elmas \& Y1lmaz, 1999) and subalkaline basaltic lavas (Genç \& Tüysüz, 2010). The metamorphism and coeval magmatism are attributed to Cimmerian collision between the Sakarya Continent and the İstanbul Zone during the closure of the Palaeotethyan ocean. The common sediments which lie unconformably upon the rocks of the İstanbul Zone, Sünnice Massif and Almacık Mountains are middle Jurassic (Callovian) to lower Cretaceous rocks (İnaltı and Bürnük formations; e.g., Yiğitbaş, Elmas \& Yılmaz, 1999) and suggest that juxtaposition of the İstanbul and Sakarya zones must have occurred before this time, much earlier than previous suggestions. Early Cretaceous (Valanginian: ca. $140 \mathrm{Ma}$ ) Rb-Sr biotite age is considered to record cooling during extensional exhumation in the footwall of normal faults that controlled the opening of the basin where İnaltı Formation and younger units in the sequence were deposited.

The Permo-Triassic magmatism, late Middle Jurassic metamorphism and magmatism, and subsequent late Jurassic-early Cretaceous cooling ages are not confined to Almacik complex only but are reported from several locations in the Pontides and Balkans (Table 7). The evidence further suggests that Cimmerian deformation and metamorphism can be traced from the Rhodope-Strandja Massif in the west to Erzincan in the east.

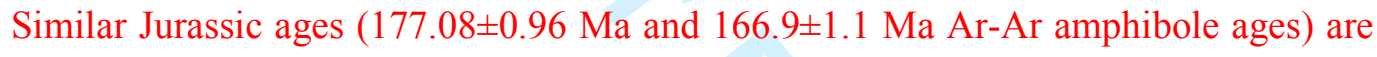
reported from amphibolites within the so-called Ankara mélange and are attributed to Jurassic northward subduction of the of the İzmir-Ankara-Erzincan ocean beneath the Pontides (Çelik et al. 2011). Dilek \& Thy (2006) dated a plagiogranite dyke in the Ankara mélange at $179 \pm 15 \mathrm{Ma}$ (U-Pb zircon ages). We think that the latest Early Jurassic ages (Toarcian) of amphibolites and plagiogranites are very similar to those reported from Erzincan ophiolites (Topuz 2012) and other coeval rocks in the Pontides and Balkans (see Table 7) and that they are related to a Palaeotethyan ocean rather than Neotethys.

The Neotethys suture(s) overlap Palaeotethys suture(s) in most places, making it difficult for others to distinguish them and it is mostly likely to see remnants of Palaeotethys ocean within the Upper Cretaceous mélange(s) along the İzmir-Ankara-Erzincan Neotethyan suture (cf. Dilek \& Thy, 2008). Likewise, the presence of late Kimmeridgian to early Tithonian radiolarites in the Arkotdağ mélange may not necessarily be related to Neotethys. 


\section{Reconstruction and conclusions}

The mafic-ultramafic Almacik complex appears to comprise Permian lower crust with subjacent subcontinental mantle, subjected during the late Middle Jurassic to high amphibolite facies metamorphism and deformation while at depth beneath the Sakarya ACM. Subsequently, during the Middle Jurassic, it was underthrust beneath the southern edge of the İstanbul Zone, before being itself thrust over the main massif of the Sakarya Continent. This latter event raised formerly deep-seated rocks to a relatively high level in the crust. The current structural and metamorphic setting of all these rocks is best explained by a complex sequence of geological events (Fig. 11).

1. Scarce inherited dates from the Almacik complex lack the Mesoproterozoic ('Rondonian') inheritance shown by the İstanbul Zone basement, thus indicating that these vestiges of continental crust were unrelated to the İstanbul Zone. Hence they are likely to have formed part of the leading margin of the Sakarya Continent, which occurs immediately to the south. The new isotopic data indicate unambiguously that the mafic-ultramafic rocks of the Almacık range are not of Precambrian (Yiğitbaş, Elmas \& Yılmaz, 1999; Yiğitbaş et al. 2004), Palaeozoic (Abdüsselamoğlu, 1959; Gözübol, 1980), or Late Cretaceous age (Y1lmaz et al. 1982, 1995; Robertson \& T. Ustaömer, 2004) but form part of a metamorphosed Permo-Triassic Cimmeride unit on the northern margin of the Sakarya Continent. Permian and Triassic ages record crystallization of the original rock formation in the Almacik complex and mark the initiation of subduction. Because these rocks have been considered as evidence for upper Cretaceous ophiolites and evidence for the presence of an Intra-Pontide ocean, their evident much older age now leaves scant support for a Mesozoic (Neotethyan) Intra-Pontide ocean in the western Pontides. However, during the late stages of the closure of the Palaeotethys Ocean, the presence of an 'active continental margin' on the Sakarya (southern) side suggests that at that time the subduction zone dipped southwards.

2. The Triassic metamorphism predated the Cretaceous closure of the northern branch of Neotethys, and was therefore unrelated to it. It seems instead to be partly a result of deepening burial of basement to the likely former Triassic Sakarya active continental margin (ACM) during the narrowing and closure of the Palaeotethys Ocean (Fig. 11a), 
with subsequent collision with the İstanbul Zone. The northward dip of the thrust planes beneath the Proterozoic basement of the İstanbul Zone hints that a change of subduction polarity may have accompanied this collision, and subsequent subduction in the area appears to have been northward.

3. Late Middle Jurassic ages (167.1 $\pm 2.1 \mathrm{Ma}$ U-Pb zircon, $172 \pm 41 \mathrm{Ma} \mathrm{Sm}-\mathrm{Nd}$ garnet and $163 \pm 20 \mathrm{Ma} \mathrm{U}-\mathrm{Pb}$ titanite ages) record subsequent metamorphism associated with over-thickening of crust, before its incipient break-up and initiation of extension. This is consistent with late Middle Jurassic magmatism, both S-type granites (ca. $165 \mathrm{Ma}$ plutonism, see figure 7 in Yiğitbaş, Elmas \& Yılmaz, 1999) and subalkaline basaltic lavas (Genç \& Tüysüz, 2010). Peregrinations of the microcontinent of which the İstanbul Zone formed a part during the Palaeozoic left little mark on its 'southern' passive margin. Even following its accretion to Laurussia and throughout the Mesozoic, no further metamorphism occurred. This means that during the collision with the Sakarya Continent in the Triassic it was not deeply buried, indicating that it was thrust over the Sakarya active continental margin.

4. Jurassic volcanism is recorded by the presence of dominantly subalkaline basaltic lavas within the Mudurnu Formation (Genç \& Tüysüz, 2010). These authors described the Mudurnu volcanics as bimodal, with a subduction signature, yet formed in an extensional setting. They could have been erupted in the Sakarya back-arc basin following the collision of the Sakarya active continental margin with the İstanbul Zone a short distance to the north.

5. $139 \pm 2 \mathrm{Ma} \mathrm{Rb}-\mathrm{Sr}$ biotite ages may record cooling during extensional exhumation. Continental fluvial clastics of the Bürnük Formation and shallow-marine carbonates of the İnaltı Formation (Callovian to Berriasian; Derman 1990) are common cover units of the İstanbul Zone and the Ballıdağ-Küre unit (Şengör \& Yılmaz 1981; Yiğitbaş, Elmas \& Y1lmaz, 1999), Simillary, Callovian rocks are unconformable above older units in the Sakarya Zone (e.g. Altıner et al. 1991; Koçyiğit et al. 1991), thus marking an important event in the history of both the İstanbul and Sakarya zones. Discussion of the significance of middle Jurassic-Early Cretaceous units in the western Pontides and the Sakarya Zone is therefore needed, but as they are coeval with the Rb-Sr biotite ages, they may likewise record an extensional environment.

6. In the later stages of collision, southward-directed thrusting must have detached the basement to the leading edge of Sakarya from the downward-moving plate and thereby brought it back up to much shallower depths. Imbrication of these rocks 
produced the structural slices which are now an important feature of the Almacik complex, as illustrated by the schematic diagrams in Figure 11. At this time the Almacik complex may have been exhumed as a horst comprising at least four thrust slices within the collision zone, and tilted so that nappes comprising slices of the former Permo-Triassic Sakarya active continental margin basal continental crust and subcrustal mantle are now exposed at the surface (Fig. 11b, c).

7. The equivalence of the Almackk complex and the Çele mafic complex remains unproven, but the lack of any Proterozoic dates obtained from the latter, despite its structural position beneath rocks of proven Proterozoic age, imply that it may prove to be an extension of the Permo-Triassic Almacik complex. Geochemical comparisons do not necessarily rule out this possibility.

8. If the Çele and Almacık complexes are related, the contact between the İstanbul Zone and Sakarya-related rocks may dip north at a shallow angle, in a similar relationship to that of the Baltic Craton and accreted Avalonian and Variscide Zones beneath Germany and Poland (e.g., Bayer et al. 1999; Grad, Guterch \& Mazur, 2002). This shallow-dipping contact, the İstanbul Zone basal thrust, marking the original Rheic Suture in northwest Turkey, has since been displaced by splays of the near-vertical North Anatolian Fault Zone.

9. We suggest that what is currently interpreted as the Intra-Pontide ocean and mapped as the Intra-Pontide suture in northwest Turkey may well be the Palaeotethys ocean and its suture respectively. But, if there is evidence for a Mesozoic Neotethyan branch in the region (which is not yet documented), then the suture zone, the Armutlu-Ovac1k zone of Elmas \& Yiğitbaş (2001), would then provide evidence for both the Palaeotethys and Neotethys oceans, and possibly the Rheic Ocean too. The recognition of relict components of each ocean is particularly hampered by later reworking along the segments of the North Anatolian Fault Zone.

\section{Acknowledgements.}

This research was funded by TÜBITTAK grant $104 \mathrm{Y} 151$ and partially by the Turkish Academy of Sciences to EB. Funding from TÜBİTAK for JAW to visit Turkey is gratefully acknowledged. Technical assistance in sample preparation and crushing at METU, Ankara was greatly appreciated. Thanks are also due to David Emley, who provided expert analytical assistance at Keele, and to NERC Isotope Geosciences Laboratory (UK) staff Adrian Wood 
for assistance with mineral separation and Matt Horstwood and Vanessa Pashley for assistance with LA-MC-ICP-MS set-up. Tuncay Taymaz is thanked for invaluable assistance during fieldwork, but this work would not have been undertaken without the considerable help from, and many discussions with Erdinç Yiğitbaş, who provided an introduction to the complex geology of the area. Comments on the significance of plagiogranites by Osman Parlak are very helpful. We also thank two reviewers whose critical comments have significantly improved the text.

\section{References}

ABDÜsSelamoglu, M.S. 1959. Almacıkdağ ile Mudurnu ve Göynük Civarının Jeolojisi [Geology of Almacıkdağı, Mudurnu and Göynük Region]. İstanbul Üniversitesi, Fen Fakültesi Monografileri 14.

Akartuna, M. 1968. Armutlu Yarımadası'nin Jeolojisi [Geology of Armutlu Peninsula]. İstanbul Üniversitesi Fen Fakültesi Monografileri 20 [in Turkish].

Akbayram, K. OKAY, A.I. \& SATIR, M. 2012. Early Cretaceous closure of the Inta-Pontide Ocean in western Pontides (northwestern Turkey). Journal of Geodynamics [in press].

Altiner, D., KoçYIĞIT, A., FARINACCI, A., NiCosia, U. \& Conti, M.A. 1991. Jurassic-Lower Cretaceous stratigraphy and paleogeographic evolution of the southern part of northwestern Anatolia. Geologica Romana 28, 13-80.

ARMSTRONG, J.T. 1991. Quantitative elemental analysis of individual microparticles with electron beam instruments. In Electron Probe Quantitation (eds K.F.J. Heinrich \& D.E. Newbury), pp. 261-315. Plenum Press, New York, N.Y.

Arpat, E., TÜtÜncÜ, K., Uysal, S. \& GöĞER, E. 1978. Safranbolu alanında KambriyenDevoniyen istifi [Cambrian-Devonian sequence of Safranbolu area]. Türkiye Jeoloji Kurumu 32. Bilimsel ve Teknik Kurultayl, Bildiri Özetleri Kitabı, 67-68.

Aumento, F. 1969. Diorites from the mid-Atlantic ridge at $45^{\circ}$ N. Science 165, 1112-1113.

AYDIN, Y. 1988. Geology of the Yıldız mountains. Selçuk University, Mühendislik-Mimarlık Fakültesi Dergisi 2, 61-74 [in Turkish].

Aydin, M., Demir, O., ÖzçEliK, Y., TerzioĞLU, N. \& SATIR, M., 1995. A geological revision of İnebolu, Devrekani, Ağl1 and Küre areas: new observations in Paleo-Tethys-NeoTethys sedimentary successions. In: Geology of the Black Sea Region (eds A. ERLER et al.), pp. 33-38. MTA Publications.

AYdin, M., ŞAhINTÜRK, Ö., SERDAR, H.S.S., ÖZÇElik, Y., AKARSU, İ., ÜnGÖR, A., ÇOKUĞRAŞ, R. \& KASAR, S. 1985. Çamdağ (Sakarya) - Sünnice dağı (Bolu) yöresinin jeolojisi [Geology of Çamdağ (Sakarya) - Sünnice dağı (Bolu) region]. Geological Bulletin of Turkey 30, 1-14.

Bayer, U., Scheck, M., Rabbel, W., Krawczyk, C.M., Gotze, H.J., Stiller, M., Beilecke, Th., Marotta A-M., Barrio-Alvers, L. \& Kuder, J. 1999. An integrated study of the NE German Basin. Tectonophysics 314, 285-307.

BLACK, L.P. \& Gulson, B.L. 1978. The age of the Mud Tank carbonatite, Strangways Range, Northern Territory. BMR Journal of Australian Geology and Geophysics 3, 227-232.

BozKURT, E., WincheSTER, J.A. \& SATIR, M. 2012. The Çele mafic-ultramafic complex and its relationship to the Proterozoic basement of the İstanbul Block. Tectonophysics [in review]. 
Bozkurt, E., Winchester, J.A., YıĞıtbaş, E. \& OtTley, C.J. 2008. Proterozoic ophiolites and mafic-ultramafic complexes marginal to the İstanbul Block: an exotic zone of Avalonian affinity in NW Turkey. Tectonophysics 461, 240-251.

BoztuĞ, D., Debon, R., Le Fort, P. \& Yilmaz, O. 1984, Geochemical characteristics of some plutons from the Kastamonu granitoid belt, northern Anatolia, Turkey. Schweizerische Mineralogische un Petrographische Mitteilungen 64, 389-403.

BoztuĞ, D. \& YILMAZ, O. 1995. Daday-Devrekani Masifi metamorfizması ve jeolojik evrimi, Kastamonu bölgesi, Batı Pontidler, Türkiye [Metamorphism and geological evolution of the Daday-Devrekani Massif, Kastamonu region, Western Pontides, Northern Turkey]. Geological Bulletin of Turkey 38, 33-52.

CASEY, J.F. 1997. Comparison of major- and trace-element geochemistry of abyssal peridotites and mafic plutonic rocks with basalts from the MARK region of the midAtlantic ridge. In Proceedings of the ODP (eds J.A. Karson, M. Cannat, D.J. Miller, D. Elthon), pp. 181-241. Science Research, vol 153. Ocean Drilling Program, College Station.

Çelik, Ö.F., GüRER, Ö.F., Aldanmaz, E., Spell, T. \& Öz, İ. 2009. Armutlu Yarımadası ve Almacıkdăg amfibolitik kayaçları için izotop ve jeokimyasal sınırlamalar [Isotopic and geochemical constraints for the amphibolitic rocks of Armutlu Peninsula and Almacikdağ]. Abstracts, 62th Geological Kurultai of Turkey, p. 466.

Çelik, Ö.F., Marzoli, A., Marschik, R. Chiaradia, M., Neubauer, F. \& Öz, İ. 2011. Early-Middle Jurassic intra-oceanic subduction in the İzmir-Ankara-Erzincan Ocean, Northern Turkey. Tectonophysics 509, 120-134.

CERIT, O. 1990. Bolu Masifinin Jeolojik ve Tektonik Incelenmesi [Geologic and Tectonic Investigation of Bolu Massif]. Ph.D. Thesis, Hacettepe University, Ankara, Turkey.

Chen, F., Siebel, W., SATIR, M., TerzioĞLU, M.N. \& SAKA, K. 2002. Geochronology of the Karadere basement, NW Turkey and implications for the geological evolution of the İstanbul Zone. International Journal of Earth Sciences 91, 469-481.

Cocherie, A., Guerrot, C. \& Rossi, P.H. 1992. Single-zircon dating by step-wise $\mathrm{Pb}$ evaporation: Comparison with other geochronological techniques applied to the Hercynian granites of Corsica, France. Chemical Geology 101, 131-141.

COCKS, L.R.M. \& TORSVIK, T.H. 2006. European geography in a global context from the Vendian to the end of the Palaeozoic. In European Lithosphere Dynamics (eds R.A. Stephenson \& D.G. Gee), pp. 83-95. Geological Society of London, Memoir 32.

Dallmeyer, R.D., Neubauer, F. \& Fritz, H. 2008. The Meliata suture in the Carpathians: regional significance and implications for the evolution of the high-pressure wedges within collisional orogens. In Tectonic Aspects of the Alpine-Dinaride-Carpathian System (eds S. Siegesmund, B. Fügenschuh, B. \& N. Froitzheim), pp. 101-115. Geological Society, London, Special Publications 298.

Dean, W.T., Monod, O., Rickards, B., Demir, O. \& Bultynck, P. 2000. Lower Palaeozoic stratigraphy and palaeontology, Karadere-Zirze area, Pontus Mountains, northern Turkey. Geological Magazine 137, 555-582.

Dick, H.J.B., Ozawa, K., Meyer, P.S., Niu, Y., Robinson, P.T., Constantin, M., Hebert, R., Maeda, J., Natland, J.H., Hirth, J.G. \& Mackie, S.M. 2002. Primary silicate mineral chemistry of a $1.5-\mathrm{km}$ section of very slow spreading lower ocean crust: ODP Hole 735B, Southwest Indian Ridge. In Proceedings of ODP (eds J.H. Natland, H.J.B. Dick, D.J. Miller, R.P. Von Herzen), pp. 1-61. Science Research, vol 176, chap 10. Ocean Drilling Program, College Station, http://www.odp.tamu.edu/publications/ 176_SR/VOLUME/CHAPTERS/SR176_10.PDF.

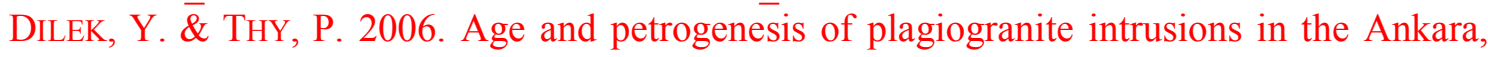 mélange, central Turkey. Island Arc 15, 44-57. 
DiLeK, Y. \& THY, P. 2009. Island arc tholeiite to boninitic melt evolution of the Cretaceous Kizildag (Turkey) ophiolite: Model for multi-stage early arc-forearc magmatism in Tethyan subduction factories. Lithos 113, i. 1-2, 68-8.

Dilek, Y., Furnes, H. \& Shallo, M. 2008. Geochemistry of the Jurassic Mirdita ophiolite (Albania) and the MORB to SSZ evolution of a marginal basin oceanic crust. Lithos 100, 174-209.

ELMAS, A. \& YIĞITBAŞ, E. 2001. Ophiolite emplacement by strike-slip tectonics between the Pontide Zone and the Sakarya Continent in northwestern Anatolia, Turkey. International Journal of Earth Sciences 90, 257-269.

Elmas, A. \& YíĞítBAŞ, E. 2005. Comment on 'Tectonic evolution of the Intra-Pontide suture zone in the Armutlu Peninsula, NW Turkey' by Robertson and Ustaömer. Tectonophysics 405, 213-221.

Elmas, A., Yilmaz, İ., YíĞíbaş, E. \& Ullrich, T. 2011. A Late Jurassic-Early Cretaceous metamorphic core complex, Strandja Massif, NW Turkey. International Journal of Earth Sciences 100, 1251-1263.

ERendil, M., GÖNCÜOĞLU, M.C., TeKelì, O., AksAy, A., KuşÇU, İ., Ürgün, B.M., Tunay, G. \& Temren, A. 1991. Armutlu Yarımadasinın Jeolojisi [Geology of Armutlu Peninsula]. Maden Tetkik ve Arama (MTA) Report no. 45529 [in Turkish, unpublished].

FloYd, P.A. \& CASTILLO, P.R. 1992. Geochemistry and petrogenesis of Jurassic ocean crust basalts, ODP Leg 129, Site 801. In Proceedings of ODP, Scientific Results 129 (eds R. Larson et al.), pp. 361-388. College Station, Texas.

GENÇ, C.Ş. \& TÜYSÜZ, O. 2010. Tectonic setting of the Jurassic bimodal magmatism in the Sakarya Zone (Central and Western Pontides), Northern Turkey: a geochemical and isotopic approach. Lithos 118, 95-111.

GÖNCÜOĞLU, M. C. \& ERENDIL, M. 1990. Armutlu yarımadasının Geç Kretase öncesi tektonik birimleri [Pre-Late Cretaceous tectonic units of Armutlu Peninsula]. Abstracts, Türkiye 8. Petrol Kongresi, Ankara, 161-168 [in Turkish].

GÖNCÜOĞLU, M.C., GÜRSU, S., TEKIN, U.K. \& KÖKSAL, S. 2008. New data on the evolution of the Neotethyan oceanic branches in Turkey: Late Jurassic ridge spreading in the IntraPontide branch. Ofioliti 33, 153-164

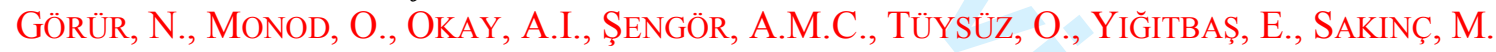
\& AKKÖK, R. 1997. Palaeogeographic and tectonic position of the Carboniferous rocks of the western Pontides (Turkey) in the frame of the Variscan belt. Bulletin de la Société Géologique de France 168, 197-205.

GÖRÜR, N. \& OKAY, A.I. 1996. A fore-arc origin for the Thrace Basin, NW Turkey. Geologische Rundschau 85, 662-668.

GözÜBOL, A.M. 1980. Geological investigation of the Mudurnu-Dokurcan-Abant area (Bolu Province) and the structural behaviour of the North Anatolian Transform Fault. Istanbul Universitesi, Fen Fakültesi Mecbuast, Seri B 45, 18-22.

Grad, M., Guterch, A. \& MAZur, S. 2002. Seismic refraction evidence for crustal structure in the central part of the Trans-European Suture Zone in Poland. 2002. In Palaeozoic Amalgamation of Central Europe (eds J.A. Winchester, T.C. Pharaoh \& J. Verniers), pp. 295-309. Geological Society, London, Special Publications 201.

Gromet, L.P., DYMeK, R.F., HASKin, L.A. \& KoroteV, R.L. 1984. The 'North American Shale Composite': its compilation, major and trace element characteristics. Geochimica Cosmochimica Acta 48, 2469-2482.

HAAs, W. 1968. Das Alt-Paläozoikum von Bithynien (Nordwest Türkei). Neues Jahrbuch fuer Mineralogie, Geologie, und Palaentologie, Abhandlungen 131, 178-242. 
Horstwood, M.S.A., Foster, G.L., Parrish, R.R., Noble, S.R. \& Nowell, G.M. 2003. Common- $\mathrm{Pb}$ corrected in-situ $\mathrm{U}-\mathrm{Pb}$ accessory mineral geochronology by LA-MCICP-MS. Journal of Analytic Atomic Spectrometry 18, 837-846.

IRVINE, T.N. \& BARAGAR, W.R.A. 1971. A guide to the chemical classification of the common rocks. Canadian Journal of Earth Sciences 8, 523-548.

KaraoĞlan, F., Parlak, O., Klötzli, U., Thöni, M. \& Koller, F. 2012. U-Pb and Sm-Nd geochronology of the Kızıldağ (Hatay, Turkey) ophiolite: implications for the timing and duration of suprasubduction zone type oceanic crust formation in southern Neotethys.

KAYA, O. 1977. Gemlik-Orhangazi alanının Paleozoyik temel yapısına yaklaşım [An approach to the structure of the Palaeozoic basement in Gemlik-Orhangazi region]. Yerbilimleri, Hacettepe Üniversitesi 3, 115-118 [in Turkish].

KAYA, O. \& KozUR, H. 1987. A new and different Jurassic to Early Cretaceous sedimentary assemblage in northwestern Turkey (Gemlik, Bursa): implications for the pre-Jurassic and Early Cretaceous tectonic evolution. Yerbilimleri 14, 253-268.

KLÖTZLI, U.S. 1999. Single zircon evaporation thermal ionisation mass spectrometry: method and procedures. Analyst 122, 1239-1248.

KOBER, B. 1986. Whole grain evaporation for ${ }^{207} \mathrm{~Pb} /{ }^{206} \mathrm{~Pb}$ age investigations on single zircons using a double-filament thermal ion source. Contributions to Mineralogy and Petrology 93, 482-490.

KOBER, B. 1987. Single zircon evaporation combined with $\mathrm{Pb}^{+}$emitter bedding for ${ }^{207} \mathrm{~Pb} /{ }^{206} \mathrm{~Pb}$-age investigations using thermal ion mass spectrometry, and implications in zirconology. Contributions to Mineralogy and Petrology 96, 63-71.

Koçyiğit, A., Altiner, D., FArinacci, A., Nicosia, U. \& ConTi, M.A. 1991. Late Triassic-Aptian evolution of the Sakarya divergent margin: implications for the opening history of the northern Neo-Tethys, in North-western Anatolia, Turkey. Geologica Romanna 27, 81-99.

Koepke, J., Feig, S.T., SnOw, J. \& Freise, M. 2004. Petrogenesis of oceanic plagiogranites by partial melting of gabbros: an experimental study. Contributions to Mineralogy and Petrology 146, 414-432

Konstantinou, A., Wirth, K.R. \& Vervoort, J. 2007. U-Pb Isotopic Dating Of Troodos Plagiogranite, Cyprus By LA-ICP-MS. In 2007 GSA Denver Annual Meeting (28-31 October 2007) Paper No. 143-16

Kozur, H., Aydin, M., Demür, O., YaKar, H., GöncüOĞLU, M.C. \& Kuru, F. 2000. New stratigraphic and palaeogeographic results from the Palaeozoic and Early Mesozoic of the Middle Pontides (northern Turkey) in the Azdavay, Devrekani, Küre and Ünebolu areas: implications for the Carboniferous-Early Cretaceous geodynamic evolution and some related remarks to the Karakaya oceanic rift basin. Geologica Croatica 53, 209-268.

KRÖNER, A. \& TODT, W. 1988. Single zircon dating constraining the maximum age of the Barberton greenstone belt, southern Africa. Journal of Geophysical Research 93, $15329-15337$.

Liati, A., Gebauer, D. \& FAnning, C.M. 2004: The age of ophiolitic rocks of the Hellenides (Vourinos, Pindos, Crete): first U-Pb ion microprobe (SHRIMP) zircon ages. Chemical Geology 207, 171-188.

LuDWIG, K.R. 2003. Isoplot 3, A Geochronological toolkit for Microsoft Excel. Berkeley Geochronology Centre Special Publications, 1a. 
Moix, P., Beccaletto, L., Kozur, H.W., Hochard, C., Rosselet, F. \& Stampfli, G.M. 2008. A new classification of the Turkish zones and its implication for paleotectonic history of the region. Tectonophysics 451, 7-39.

MuKASA, S.B. \& LudDEN, J.N. 1987. Uranium-lead ages of plagiogranites from the Troodos ophiolite, Cyprus, and their tectonic significance. Geology 15, 825-828.

Murphy, J.B., NANCE, R.D. \& KePPIE, J.D. 2002. Discussion and reply: West African proximity of the Avalon Zone in the latest Precambrian. Geological Society of America Bulletin 114, 1049-1052.

NANCE, R.D. \& MurPhy, J.B. 1994. Contrasting basement isotopic signatures and the palinspastic restoration of peripheral orogens: example from the Neoproterozoic Avalon-Cadomian belt. Geology 22, 617-620.

Natal'in, B.A., Sunal, G. \& Toraman, E. 2005. The Strandja arc: anatomy of collision after long-lived arc parallel tectonic transport. In The Strandja Arc: Anatomy of Collision After Long-lived Arc Parallel Tectonic Transport (ed E.V. Sklyarov), pp. 240-245. IEC SB RAS, Irkutsk.

Natal'In, B.A., Sunal, G., Satir, M. \& Toraman, E. 2012. Tectonics of the Strandja Massif, NW Turkey: history of a long-lived arc at the northern margin of PalaeoTethys. Turkish Journal of Earth Sciences 21, 755-798.

NzegGe, O.M. 2008. Petrogenesis and Geochronology of the Deliktaş, Sivrikaya and Devrekani Granitoids and Basements in the Kastamonu Belt, Central Pontides (NW Turkey): Evidence of Late Palaeozoic-Mesozoic Plutonism, and Geodynamic Interpretation. $\mathrm{PhD}$ Thesis, Tübingen University, Germany.

NzEGGE, O.M. \& SATIR, M. 2007. Geochronology of the basement of the Central Pontides, NW Turkey: a confirmation of Eurasian origin. Geophysical Research Abstracts 9, 08626.

OKAY, A.I. 2000. Was the Late Triassic orogeny in Turkey caused by the collision of an oceanic plateau? In Tectonics and Magmatism in Turkey and Surrounding Area (eds E. BozKurT, J.A. Winchester \& J.D.A PIPER), Geological Society, London, Special Publication 173, 25-41.

OKAY, A.I. 2008. Geology of Turkey: a synopsis. Anschnitt 21, 19-42.

OKay, A.I., Bozkurt, E., SATIR, M., YiĞITBAŞ, E., Crowley, Q.C. \& Shang, C.K. 2008. Defining the southern margin of Avalonia in the Pontides: geochronological data from the Late Proterozoic and Ordovician granitoids from NW Turkey. Tectonophysics 461, 252-264.

OKAY, A.I. \& GÖNCÜOĞLU, C. 2004. The Karakaya Complex: a review of data and concepts. Turkish Journal of Earth Sciences 13, 77-97.

OKAY, A.I. \& MONIÉ, P. 1997. Early Mesozoic subduction in the Eastern Mediterranean: evidence from Triassic eclogite in northwest Turkey. Geology 25, 595-598.

OKAY, A.I., MONOD, O. \& MonIÉ, P. 2002. Triassic blueschists and eclogites from northwest Turkey: vestiges of the Paleo-Tethyan subduction. Lithos 64, 155-178.

Okay, A.I., SAtir, M., Maluski, H., Siyako, M., Monie, P., Metzger, R. \& Akyüz, S. 1996. Paleo- and Neo-Tethyan events in northwestern Turkey: geologic and geochronologic constraints. In: Paleo- and Neo-Tethyan Events in Northwestern Turkey: Geologic and Geochronologic Constraints (eds A. Yin \& M. Harrison), pp. 420-441. Cambridge University Press, Cambridge.

Okay, A.I., Satir, M. \& Siebel, W. 2006a. Pre-Alpide orogenic events in the Eastern Mediterranean region. In European Lithosphere Dynamics (eds D.G. Gee \& R.A. Stephenson). Geological Society, London, Memoirs 32, 389-405. 
Okay, A.I. SATIR, M., TÜysüz, O., AKYÜZ, S. \& Chen, F. 2001. The tectonics of the Strandja Massif: Variscan and mid-Mesozoic deformation and metamorphism in the northern Aegean. Geologische Rundschau 90, 217-233.

OKay, A.I., Sunal, G., Sherlock, S. \& TÜYSÜZ, O. 2010. Jurassic high-temperature metamorphism in the Central Pontides. Abstracts, $63^{\text {rd }}$ Geological Congress of Turkey.

OKAY, A.I., ŞENGÖR, A.M.C. \& GÖRÜR, N. 1994. Kinematic history of the opening of the Black Sea and its effect on the surrounding regions. Geology 22, 267-270.

OKAY, A.I., SiYAKO, M. \& BÜRKAN, K.A. 1991. Geology and tectonic evolution of the Biga Peninsula, northwest Turkey. Bulletin of the Technical University of Istanbul 44, $191-256$.

OKAY, A.I. \& TÜYsÜZ, O. 1999. Tethyan sutures of northern Turkey. In Tethyan Sutures of Northern Turkey (eds B. Durand, L. Jolivet, F. Horvath, \& M. Seranne), pp. 475-515. Geological Society, London, Special Publications 156.

Okay, A.I., TÜYsüz, O., SAtir, M., ÖZKan-Altiner, S., Altiner, D., Sherlock, S. \& Eren, R.H. 2006b. Cretaceous and Triassic subduction-accretion, high-pressure-lowtemperature metamorphism, and continental growth in the Central Pontides, Turkey. Geological Society of America Bulletin 118, 1247-1269.

OKAY, N., ZACK, T., OKAY, A.I. \& BARTH, M. 2011. Sinistral transport along the TransEuropean Suture Zone: detrital zircon-rutile geochronology and sandstone petrography from the Carboniferous flysch of the Pontides. Geological Magazine 148, 380-403.

ÖZCAN, Z., OKAY, A.I., ÖZCAn, E., HAKYEMEZ, A. \& ÖZKAn-Altiner, S. 2012. Late Cretaceous-Eocene geological evolution of the Pontides based on new stratigraphic and palaeontologic data between the Black Sea coast and Bursa (NW Turkey). Turkish Journal of Earth Sciences 21, 933-960.

ÖZGÜL, N. 2012. Stratigraphy and some structural features of the İstanbul Palaeozoic. Turkish Journal of Earth Sciences 21, 817-866.

PeArCE, J.A. \& NorRY, M.J. 1979. Petrogenetic implications of Ti, Zr, Y and Nb variations in volcanic rocks. Contributions to Mineralogy and Petrology 69, 241-254.

Robertson, A.H.F. \& UstaÖMER, T. 2004. Tectonic evolution of the Intra-Pontide suture zone in the Armutlu Peninsula, NW Turkey. Tectonophysics 381, 175-209.

Robertson, A.H.F. \& UstAöMER, T. 2012. Testing alternative tectono-stratigraphic interpretations of the Late Palaeozoic-Early Mesozoic Karakaya Complex in NW Turkey: support for an accretionary origin related to northward subduction of Palaeotethys. Turkish Journal of Earth Sciences 21, 961-1007.

Robertson, A.H.F., Dixon, J. E., Brown, S., Collins, A., Morris, A., Pickett, E.A., SHARP, I. \& USTAÖMER, T. 1996. Alternative tectonic models for the Late PalaeozoicEarly Tertiary development of Tethys in the Eastern MediZonean region. In Palaeomagnetism and Tectonics of the MediZonean Region (eds A. Morris \& D.H. Tarling). Geological Society, London, Special Publications 105, 239-263.

Robertson, A.H.F., Ustaömer, T., Pickett, E.A., Collins, A.A., Andrew, T. \& Dixon, J.E. 2004. Testing models of Late Palaeozoic-Early Mesozoic orogeny in Western Turkey: support for an evolving open-Tethys model. Journal of the Geological Society, London 161, 501-511.

Samson, S.D., D’Lemos, R.S., Miller, B.V. \& Hamilton, M.A. 2005. Neoproterozoic palaeogeography of the Cadomia and Avalon zones: constraints from detrital zircon U-Pb ages. Journal of the Geological Society, London 162, 6571.

SAYIT, K. \& GÖNCÜOĞLU, M.C. 2012. Geodynamic evolution of the Karakaya mélange complex, Turkey: a review of geological and petrological constraints. Journal of Geodynamics [in press]. 
Schofield, D.I., Horstwood, M.S.A., Pitfield, P.E.J., Crowley, Q.G., Wilkinson, A.F. \& SIDATY, H.O. 2006. Timing and kinematics of Eburnean tectonics in the central Reguibat Shield, Mauretania. Journal of the Geological Society, London 163, $549-560$.

ŞENGÖR, A.M.C. 1984. The Cimmeride Orogenic System and the Tectonics of Eurasia. Geological Society of America Special Paper 195, 82 p.

ŞENGÖR, A.M.C. 1987. Tectonics of the Tethysides: orogenic collage development in a collisional setting. Annual Reviews of Earth and Planetary Sciences 15, 213-244.

ŞENGÖR, A.M.C. \& YILMAZ, Y. 1981. Tethyan evolution of Turkey, a plate tectonic approach. Tectonophysics 75, 181-241.

ŞEngÖR, A.M.C., YILMAZ, Y. \& Ketin, İ. 1980. Remnants of a pre-Late Jurassic ocean in northern Turkey, fragments of Permo-Triassic Paleo-Tethys? Geological Society of America Bulletin 91, 599-609.

SHERVAIS, J.W. 1982. Ti-V plots and the petrogenesis of modern and ophiolitic lavas. Earth Planetary Science Letters 57, 101-118.

Siebel, W., Blaha, U., Chen, F. \& RohrmÜller, J. 2004. Geochronology and geochemistry of a dyke-host rock association and implications for the formation of the Bavarian Pfal shear zone, Bohemian massif. International Journal of Earth Sciences 94, 8-23.

SilantYeV, S.A. 1998. Origin conditions of the mid-Atlantic Ridge plutonic complex at $13^{\circ}-$ $17^{\circ}$ N. Petrology 6, 381-421

Stampfli, G.M. 2000. Tethyan oceans. In Tectonics and Magmatism in Turkey and the Surrounding Area (eds E. Bozkurt, J.A. Winchester \& J.A.D. Piper). Geological Society, London, Special Publications 173, 1-23.

StAMPfli, G.M. \& Borel, G.D. 2002. A plate tectonic model for the Paleozoic and Mesozoic constrained by dynamic plate boundaries and restored synthetic oceanic isochrons. Earth and Planetary Science Letters 196, 17-33.

STEIGER, R.H. \& JÄGER, E. 1977. Subcommision on geochronology: convention on the use of decay constants in geo- and cosmo-chronology. Earth and Planetary Science Letters 36, 359-362.

Sunal, G., NAtal'in, B.A., SatiR, M. \& Toraman, E. 2006. Paleozoic magmatic events in the Strandja Massif, NW Turkey. Geodinamica Acta 19, 283-300.

Sunal, G., Satir, M., Natal'In, B.A. \& Toroman, E. 2008. Paleotectonic position of the Strandja Massif and surrounding continental blocks based on zircon $\mathrm{Pb}-\mathrm{Pb}$ Age studies. International Geology Review 50, 519-545.

Sunal, G., Satir, M., NAtal'in, B.A., Topuz, G. \& Vonderschmidt, O. 2011. Metamorphism and diachronous cooling in a contractional orogen: the Strandja Massif, NW Turkey. Geological Magazine 148, 580-596.

THAYER, T.P. 1977. Some implications of sheeted dike swarms in ophiolitic complexes. Geotectonics 11, 419-426.

TOKAY, M. 1973. Geological observations on the North Anatolian Fault Zone between Gerede and Ilgaz. Proceedings of North Anatolian Fault and Earthquake Symposium. MTA Publications, 12-29.

Tilton, G.R., Hopson, C.A. \& Wright, J.E. 1981. Uranium-lead isotopic ages of the Samail ophiolite, Oman, with applications to Tethyan Sea ridge tectonics. Journal of Geophysical Research 86, 2763-2776.

Topuz, G. 2012.

Topuz, G., Altherr, R., Kalt, A., Satir, M., Werner, O. \& Schwartz, W.H. 2004. Aluminous granulites from the Pulur Complex, NE Turkey: a case of partial melting, efficient melt extraction and crystallisation. Lithos 72, 183-207. 
Topuz, G., Altherr, R., Schwartz,W.H., Dokuz, A. \& Meyer, H.-P. 2007. Variscan amphibolites-facies rocks from the Kurtoğlu metamorphic complex (Gümüşhane area, Eastern Pontides, Turkey). International Journal of Earth Sciences 96, 861-873.

Topuz, G., Altherr, R., Siebel, W., Schwarz, W.H., ZACK, T., HasözBeK, A., Barth, M., SATIR, M. \& ŞEN, C. 2010. Carboniferous high-potassium I-type granitoid magmatism in the Eastern Pontides: The Gümüşhane pluton (NE Turkey). Lithos 116, 92-110

TÜYsÜZ, O. 1999. Geology of the Cretaceous sedimentary basins of the Western Pontides. Geological Journal 34, 75-93.

Ustaömer, P.A., Mundil, R. \& Renne, P.R. 2005. U/Pb and $\mathrm{Pb} / \mathrm{Pb}$ zircon ages for arcrelated intrusions of the Bolu Massif (W Pontides, NW Turkey): evidence for Late Precambrian (Cadomian) age. Terra Nova 17, 215-223.

UstaÖMER, P.A. 1999. Pre-Early Ordovician Cadomian arc-type granitoids, the Bolu Massif, West Pontides, northern Turkey: geochemical evidence. International Journal of Earth Sciences 88, 2-12.

UstaÖMer, P.A. \& Rogers, G. 1999. The Bolu Massif: remnant of a pre-Early Ordovician active margin in the West Pontides, northern Turkey. Geological Magazine 136, 579-592.

Ustä̈mer, P.A., Ustä̈mer, T., Gerdes, A. \& Zulauf, G. 2011. Detrital zircon ages from a Lower Ordovician quartzite of the İstanbul exotic Zone (NW Turkey): evidence for Amazonian affinity. International Journal of Earth Sciences 100, 23-41.

Ustaömer, P.A., Ustä̈mer, T. \& Robertson, A.H.F. 2012. Ion Probe U-Pb dating of the Central Sakarya basement: a peri-Gondwana terrane intruded by late Lower Carboniferous subduction/collision-related granitic rocks. Turkish Journal of Earth Sciences 21, 905-932.

UstaÖMer, T. \& RoBertson, A.H.F. 1993. Late Palaeozoic-Early Mesozoic marginal basins along the active continental southern continental margin of Eurasia: evidence from the Central Pontides (Turkey) and adjacent regions. Geological Journal 28, 219-238.

USTAÖMER, T. \& ROBERTSON, A.H.F. 1994. Late Palaeozoic marginal basin and subductionaccretion: evidence from the Palaeotethyan Küre Complex, Central Pontides, N. Turkey. Journal of the Geological Society, London 151, 291-305.

UstaÖMER, T. \& RoBERTSON, A.H.F. 1997. Tectonic-sedimentary evolution of the north Tethyan margin in the Central Pontides of northern Turkey. In Regional and Petroleum Geology of the Black Sea and Surrounding Region (ed A.G. Robinson), pp. 255-290. American Association of Petroleum Geologists, Memoirs 68.

Ustaömer, T. \& Robertson, A.H.F. 1999. Geochemical evidence used to test alternative plate tectonic models for pre-Upper Jurassic (Palaeotethyan) units in the Central Pontides, N Turkey. Geological Journal 34, 25-53.

Warren, C.J., Parrish, R.R., Waters, D.J. \& Searle, M.P. 2005. Dating the geologic history of Oman's Semail ophiolite: insights from U-Pb geochronology. Contributions to Mineralogy and Petrology 150, 403-422.

WinCHESTER, J.A. \& FLOYD, P.A. 1977. Geochemical discrimination of different magma series and their differentiation products using immobile elements. Chemical Geology 20, 325-343.

Winchester, J.A. \& PACE Network TeAm 2002. Palaeozoic amalgamation of Central Europe: new results from recent geological and geophysical investigations. Tectonophysics 360, 5-21.

Winchester, J.A., Pharaoh, T.C., Verniers, J., IoAne, D. \& Seghedi, A. 2006. Palaeozoic accretion of Gondwana-derived Zones to the East European Craton: recognition of detached Zone fragments dispersed after collision with promontories. In European 
Lithosphere Dynamics (eds R.A. Stephenson \& D.G. Gee), pp. 323-332. Geological Society of London, Memoir 32.

WinCHESTER, J.A., VAN STAAL, C.R. \& LANGTON, J.P. 1992. The Ordovician volcanics of the Elmtree-Belledune inlier and their relationships to volcanics of the northern Miramichi Highlands, New Brunswick. Canadian Journal of Earth Sciences 29, 1430-1447.

YIĞITBAŞ, E., ElmaS, A. \& YILMAZ, Y. 1999. Pre-Cenozoic tectono-stratigraphic components of the Western Pontides and their geological evolution. Geological Journal 34, 55-74.

Yiğitbaş, E., Kerrich, R., Yilmaz, Y., Elmas, A. \& XIE, Q. 2004. Characteristics and geochemistry of Precambrian ophiolites and related volcanics from the İstanbulZonguldak Unit, northwestern Anatolia, Turkey: following the missing chain of the Precambrian south European Suture Zone to the east. Precambrian Research 132, 179-206.

YiĞıtBaŞ, E., Winchester, J.A. \& OtTLEy, C.J. 2008. The Geochemistry and Setting of the Demirci Paragneisses of the Sünnice Massif, NW Turkey. Turkish Journal of Earth Sciences 17, 421-431.

YILMAZ, I. 1977. The absolute age and genesis of the Sancaktepe granite (Kocaeli Peninsula)]. Türkiye Jeoloji Kurumu Bülteni 20, 17-20 [in Turkish].

YILMAZ, O. 1980. Daday-Devrekani masifi kuzeydoğu kesimi litostratigrafi birimleri ve tektoniği [Lithostratigraphic units and tectonics of northeastern part of the DadayDevrekani Massif]. Yerbilimleri 5-6,101-135.

YilmaZ, O. \& Bonhomme, M.G. 1991, K-Ar isotopic age evidence for a Lower to Middle Jurassic low-pressure and a Lower Cretaceous high-pressure metamorphic events in north-central Turkey. Terra Abstracts 3, p. 501.

YILmAZ, O. \& BozTUĞ, D. 1986. Kastamonu granitoid belt of northern Turkey: first arc plutonism product related to the subduction of the Paleo-Tethys. Geology 14, 179-183.

YilmAZ, Y. 1990. Allochthonous terranes in the Tethyan Middle East, Anatolia and surrounding regions. Philosophical Transactions of Royal Society of London A 331, 611-624.

YilmaZ, Y., Genç, C., YiĞITBAŞ, E., BozCU, M.\& Yilmaz, K. 1995. Geological evolution of the Late Mesozoic continental margin of northwestern Anatolia. Tectonophysics 243, $155-171$.

Yilmaz, Y., GÖZÜBOL, A.M. \& TÜYSÜZ, O. 1982. Geology of an area in and around the North Anatolian Transform Fault between Bolu and Akyasi. In Multidisciplinary Approach to Earthquake Prediction (eds A.M. Iş1kara \& A. Vogel), pp. 45-67. Proceedings of International Symposium on Earthquake Prediction in the North Anatolian Fault Zone. (Sriedr) Wieweg, Braunschweig.

Yilmaz, Y., TÜYsüZ, O., YiĞITBaŞ, E., GenÇ, S. C. \& ŞEngöR, A.M.C. 1997. Geology and tectonic evolution of the Pontides. In: Geology and Tectonic Evolution of the Pontides (ed A.G. Robinson), pp. 183-226. AAPG Memoir 68.

YORK, D. 1969. Least-square fitting with a straight line with correlated errors. Earth and Planetary Science Letters 5, 320-324.

ZAPCI, C., AKYÜZ, H.S. \& SunAL, G., 2003. An approach to the structural evolution of the İstanbul Zone. Proceeding of the Symposium on the Geology of the Istanbul Region, İstanbul, 5-14 [in Turkish]. 


\section{Figure Captions}

Figure 1. Tectonic units of Turkey showing the location of the İstanbul Zone (from Okay \& Tüysüz, 1999).

Figure 2. Simplified geological map of İstanbul Block showing the location of Almac1k area (fromYiğitbaş et al. 2004).

Figure 3. Simplified geological map showing the location of the Almacik complex (adapted from the 1: 5000 scale geological map of Turkey, published by MTA). The age of Almacik complex ultramafic and mafic rocks in Almacik Mountains are shown late Cretaceous as in the original map but they are proven much older, Permo-Triassic, in the present study.

Figure 4. Map showing the setting and field relationships of the varied mafic and ultramafic rocks that make up the Almacik Massif. Locations of numbered samples along the principal road section are given.

Figure 5. (a) Thin-section (xpl) of harzburgite from the Almacik road section; (b) websterite outcrop; (c) thin-section (xpl) of websterite consisting of a granoblastic intergrowth of orthopyroxene and clinopyroxene from the Almacik road section.

Figure 6. Discrimination diagrams distinguishing the chemistry of the various ultramafic rocks. (a) $\mathrm{CaO}-\mathrm{MgO}$; (b) $\mathrm{Ni}-\mathrm{Cr}$; (c) $\mathrm{Al}_{2} \mathrm{O}_{3}-\mathrm{MgO}$; (d) Chondrite-normalised $\mathrm{REE}$ profiles. Symbols: filled circles- harzburgite from Almacik; triangles- websterite from Almacik.

Figure 7. Discrimination diagrams showing the chemistry of the Almac1k Massif mafic rocks. (a) AFM diagram (Irvine \& Baragar, 1971); (b) V-Ti diagram (Shervais, 1982); (c) $\mathrm{V} / \mathrm{Zr}-\mathrm{Y} / \mathrm{Sr}$ diagram to distinguish the four different metabasite suites; (d) $\mathrm{Cr} / \mathrm{Fe}_{2} \mathrm{O}_{3}$ (total)-Sr/Y. Symbols: Filled diamonds- Eastern Tholeiites; trianglesResthouse Metabasites; filled square- Akçalaan Metabasite; diamonds- Western Metabasites.

Figure 8. Chondrite-normalised rare earth and N-MORB-normalised multi-element profiles for mafic rocks from the Almacik Massif. Symbols as in Figure 5.

Figure 9. Field views of the plagiogranite samples selected for age dating: (a) a general view of the plagiogranite dyke intrusive into metabasic rocks southeast of the resthouse (sample 60-I; GPS coordinates: $3500329100^{\circ} \mathrm{E}$ and $4496843^{\circ} \mathrm{N}$ ). The dyke is cut and displaced along a low-angle fault. It is deformed and metamorphosed and contains orange-red garnet crystals; (b) a close-up view of meso-scale folds deforming the plagiogranite dyke; (c, d) views of the location of sample 61-I (GPS coordinates: $350329048^{\circ} \mathrm{E}$ and $4496197^{\circ} \mathrm{N}$ ) and 65 (GPS coordinates: $350329948^{\circ} \mathrm{E}$ and $\left.4495644^{\circ} \mathrm{N}\right)$; they are dykes intruding the host rock metabasics; (e, f) close-up views of pegmatitic gabbros with megacrystic hornblende. The man is $166 \mathrm{~cm}$ tall, pencil and hammer are 15 and $33 \mathrm{~cm}$ long, respectively; and the diameter of the coin is $3 \mathrm{~cm}$.

Figure 10. (a, b) Isotopic dates obtained from a plagiogranite dyke emplaced into the resthouse metabasites, sample 60-I: (a) diagram showing the distribution of $\mathrm{Pb}-\mathrm{Pb}$ zircon evaporation ages; (b) U-Pb concordia plot showing zircon ages derived from LA-MC-ICP-MS analyses. (c, d) Isotopic dates obtained from a granite dyke in the resthouse metabasite, sample 61-I: (c) diagram showing the distribution of $\mathrm{Pb}-\mathrm{Pb}$ zircon evaporation ages; (d) histogram showing the distribution of ${ }^{207} \mathrm{~Pb} /{ }^{206} \mathrm{~Pb}$ ratios vs. number of ${ }^{207} \mathrm{~Pb} /{ }^{206} \mathrm{~Pb}$ ratios derived from evaporation of zircons. (e) $\mathrm{U}-\mathrm{Pb}$ discordia diagram of titanite grains from sample 60-I. (f) Diagram showing the distribution of $\mathrm{Pb}-\mathrm{Pb}$ zircon evaporation ages from sample 65 .

Figure 11. Schematic staged reconstruction of the Almacik Complex, demonstrating how subcontinental Sakarya basal crust and mantle could have been emplaced into its 
present position vis-a-vis the İstanbul Block: (a) formation of the Almacık Complex as basement to an active continental margin on the north side of the Sakarya Block; (b) illustrating the location of thrusting at the time of collision. The red lines indicate the position of the present road section; (c) shows the Almacik Complex following nappe stacking: the red line is the road section. 


\section{Table Captions}

Table 1. Full analyses of ultramafic rocks in the Almacik Complex. Abbreviations: wb websterite; hzb - harzburgite; srphzb - serpentinized harzburgite.

Table 2. Full analyses of mafic rocks from the Almacik road section. Abbreviations: WMB Western Metabasites; AkcMB - Akçalaan metabasite; RestMB - resthouse metabasites; E-IAT - eastern tholeiites; Plaggr - Plagiogranite.

Table 3. Zircon $\mathrm{Pb}$ evaporation data including radiogenic ${ }^{207} \mathrm{~Pb} /{ }^{206} \mathrm{~Pb}$ ratios and corresponding age data for samples 60-I, 61-I and 65.

Table 4. Laser ablation ICP-MS U-Pb zircon data and calculated apparent ages from sample $60-\mathrm{I}$.

Table 5. $\mathrm{Rb}-\mathrm{Sr}$ isotopic data and calculated age of biotite from sample 60-I.

Table 6. Titanite U-Pb data from sample 61-I.

Table 7. A summary table showing isotopic data from Rhodope-Strandja in the west to Erzincan in the East. 


\begin{tabular}{|c|c|c|c|c|c|c|c|c|c|}
\hline Sample & $03 \backslash 59$ & 03160 & $03 \backslash 61$ & 03\52 & 03153 & $03 \backslash 57$ & EY202* & EY201* & EY201A* \\
\hline & wb & wb & $w b$ & hzb & hzb & srphzb & srphzb & srptro & srptro \\
\hline $\mathrm{SiO} 2$ & 53.48 & 52.08 & 54.56 & 42.49 & 42.35 & 41.35 & 36.43 & 50.05 & 49.58 \\
\hline TiO2 & 0.15 & 0.16 & 0.19 & 0.16 & 0.03 & 0.02 & 0.03 & 0.14 & 0.15 \\
\hline $\mathrm{Al} 2 \mathrm{O} 3$ & 1.90 & 2.39 & 2.09 & 2.79 & 1.99 & 0.92 & 1.73 & 7.63 & 8.30 \\
\hline $\mathrm{Fe} 2 \mathrm{O} 3 \mathrm{~T}$ & 5.81 & 6.06 & 6.99 & 8.41 & 9.45 & 8.57 & 13.45 & 8.50 & 7.89 \\
\hline $\mathrm{MnO}$ & 0.13 & 0.14 & 0.16 & 0.13 & 0.15 & 0.19 & 0.17 & 0.13 & 0.12 \\
\hline $\mathrm{MgO}$ & 21.83 & 22.13 & 22.26 & 40.65 & 39.08 & 38.34 & 34.75 & 23.72 & 22.79 \\
\hline $\mathrm{CaO}$ & 16.08 & 16.70 & 13.58 & 2.99 & 2.69 & 0.95 & 0.79 & 7.61 & 8.65 \\
\hline $\mathrm{Na} 2 \mathrm{O}$ & 0.27 & 0.21 & 0.15 & 0.08 & 0.11 & 0.00 & 0.00 & 1.00 & 1.09 \\
\hline $\mathrm{K} 2 \mathrm{O}$ & 0.01 & 0.01 & 0.00 & 0.07 & 0.03 & 0.00 & 0.04 & 0.10 & 0.09 \\
\hline P2O5 & 0.00 & 0.00 & 0.00 & 0.00 & 0.00 & 0.00 & 0.00 & 0.00 & 0.00 \\
\hline LOI & 0.14 & 0.19 & 0.10 & 2.83 & 3.63 & 9.65 & 14.52 & 1.16 & 1.37 \\
\hline$S$ & 0.02 & 0.01 & 0.01 & 0.01 & 0.01 & 0.07 & 0.00 & 0.00 & 0.00 \\
\hline Total & 99.83 & 100.09 & 100.10 & 100.60 & 99.51 & 100.07 & 101.91 & 100.04 & 100.03 \\
\hline
\end{tabular}

\begin{tabular}{|c|c|c|c|c|c|c|c|c|c|}
\hline $\mathrm{Ba}$ & 7 & 10 & 11 & 10 & 15 & 2 & 6 & 6 & 8 \\
\hline $\mathrm{Cl}$ & 15 & 13 & 31 & 75 & 57 & 291 & 0 & 0 & 0 \\
\hline Co & 0 & 47 & 49 & 99 & 0 & 109 & 158 & 60 & 54 \\
\hline $\mathrm{Cr}$ & 2988 & 2319 & 3695 & 2854 & 2654 & 2680 & 2996 & 2242 & 2471 \\
\hline Cs & 0.00 & 0.03 & 0.00 & 0.35 & 0.00 & 0.09 & 0.00 & 0.00 & 0.00 \\
\hline $\mathrm{Cu}$ & 115 & 335 & 117 & 27 & 24 & 9 & 0 & 0 & 0 \\
\hline $\mathrm{Ga}$ & 3 & 5 & 3 & 3 & 1 & 1 & 0 & 0 & 0 \\
\hline $\mathrm{Hf}$ & 0.00 & 0.52 & 0.16 & 0.03 & 0.00 & 0.02 & 0.02 & 0.52 & 0.15 \\
\hline $\mathrm{Nb}$ & 2.0 & 0.1 & 0.0 & 0.1 & 0.0 & 0.0 & 0.1 & 0.1 & 0.1 \\
\hline $\mathrm{Ni}$ & 604 & 572 & 246 & 1946 & 2070 & 2125 & 2077 & 712 & 687 \\
\hline $\mathrm{Pb}$ & 2 & 3 & 6 & 0 & 1 & 2 & 0 & 0 & 0 \\
\hline $\mathrm{Rb}$ & 0 & 1 & 0 & 3 & 2 & 0 & 0 & 1 & 0 \\
\hline $\mathrm{Sc}$ & 0 & 45 & 39 & 15 & 0 & 7 & 0 & 0 & 0 \\
\hline $\mathrm{Sr}$ & 52 & 24 & 14 & 1 & 1 & 5 & 10 & 58 & 68 \\
\hline $\mathrm{Ta}$ & 0.00 & 0.01 & 0.00 & 0.01 & 0.00 & 0.00 & 0.00 & 0.00 & 0.00 \\
\hline Th & 2.0 & 0.0 & 0.0 & 0.1 & 2.0 & 0.0 & 0.0 & 0.1 & 0.0 \\
\hline U & 0.00 & 0.01 & 0.01 & 0.00 & 0.00 & 0.00 & 0.02 & 0.02 & 0.02 \\
\hline v & 108 & 119 & 122 & 74 & 68 & 27 & 27 & 92 & 113 \\
\hline Y & 8 & 9 & 9 & 4 & 3 & 2 & 0 & 1 & 2 \\
\hline $\mathrm{Zn}$ & 38 & 37 & 60 & 52 & 53 & 53 & 0 & 0 & 0 \\
\hline $\mathrm{Zr}$ & 10 & 11 & 11 & 6 & 7 & 8 & 1 & 5 & 4 \\
\hline
\end{tabular}

\begin{tabular}{|c|c|c|c|c|c|c|c|c|c|}
\hline La & 0.0 & 0.5 & 0.4 & 0.1 & 0.0 & 0.1 & 0.1 & 0.7 & 0.6 \\
\hline $\mathrm{Ce}$ & 0.0 & 1.8 & 1.4 & 0.1 & 0.0 & 0.2 & 0.2 & 1.1 & 1.3 \\
\hline $\mathrm{Pr}$ & 0.00 & 0.36 & 0.31 & 0.02 & 0.00 & 0.03 & 0.03 & 0.13 & 0.16 \\
\hline $\mathrm{Nd}$ & 0.0 & 2.1 & 1.7 & 0.1 & 0.0 & 0.2 & 0.7 & 0.6 & 0.8 \\
\hline $\mathrm{Sm}$ & 0.00 & 0.73 & 0.62 & 0.08 & 0.00 & 0.04 & 0.02 & 0.19 & 0.31 \\
\hline $\mathrm{Eu}$ & 0.00 & 0.22 & 0.20 & 0.03 & 0.00 & 0.01 & 0.00 & 0.33 & 0.43 \\
\hline Gd & 0.00 & 0.97 & 0.91 & 0.17 & 0.00 & 0.05 & 0.02 & 0.26 & 0.36 \\
\hline $\mathrm{Tb}$ & 0.00 & 0.17 & 0.16 & 0.04 & 0.00 & 0.01 & 0.00 & 0.05 & 0.06 \\
\hline Dy & 0.00 & 1.04 & 1.03 & 0.30 & 0.00 & 0.07 & 0.03 & 0.35 & 0.41 \\
\hline Ho & 0.00 & 0.22 & 0.22 & 0.07 & 0.00 & 0.01 & 0.00 & 0.07 & 0.09 \\
\hline $\mathrm{Er}$ & 0.00 & 0.60 & 0.06 & 0.22 & 0.00 & 0.05 & 0.02 & 0.19 & 0.25 \\
\hline $\mathrm{Tm}$ & 0.00 & 0.09 & 0.10 & 0.04 & 0.00 & 0.01 & 0.01 & 0.03 & 0.04 \\
\hline $\mathrm{Yb}$ & 0.00 & 0.56 & 0.60 & 0.25 & 0.00 & 0.06 & 0.02 & 0.19 & 0.25 \\
\hline Lu & 0.00 & 0.08 & 0.09 & 0.04 & 0.00 & 0.01 & 0.00 & 0.02 & 0.03 \\
\hline
\end{tabular}


Table 2 basic gneisses from the Almacık road section

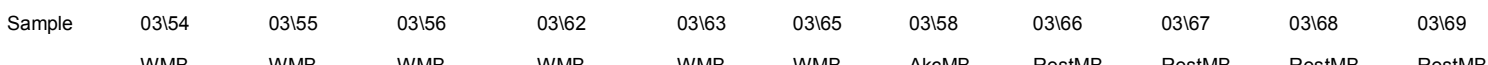

\begin{tabular}{|c|c|c|c|c|c|c|c|c|c|c|c|}
\hline $\mathrm{SiO}_{2}$ & 49.58 & 49.94 & 48.89 & 48.17 & 46.36 & 47.17 & 43.15 & 54.05 & 54.35 & 51.08 & 47.32 \\
\hline $\mathrm{TiO}_{2}$ & 1.79 & 2.96 & 0.57 & 1.84 & 1.35 & 1.28 & 0.46 & 0.15 & 1.63 & 0.37 & 1.31 \\
\hline $\mathrm{Al}_{2} \mathrm{O}_{3}$ & 13.51 & 13.82 & 17.00 & 14.82 & 14.78 & 15.12 & 16.81 & 25.23 & 18.63 & 13.49 & 17.79 \\
\hline $\mathrm{Fe}_{2} \mathrm{O}_{3} \mathrm{~T}$ & 12.39 & 13.85 & 6.75 & 10.69 & 11.10 & 12.00 & 8.55 & 2.57 & 9.17 & 10.27 & 11.95 \\
\hline $\mathrm{MnO}$ & 0.17 & 0.15 & 0.11 & 0.16 & 0.16 & 0.20 & 0.12 & 0.03 & 0.16 & 0.13 & 0.12 \\
\hline $\mathrm{MgO}$ & 6.52 & 5.09 & 9.30 & 8.59 & 8.61 & 8.03 & 10.18 & 1.93 & 2.33 & 9.90 & 4.94 \\
\hline $\mathrm{CaO}$ & 10.11 & 9.58 & 13.84 & 12.03 & 13.81 & 12.18 & 17.06 & 9.20 & 6.08 & 10.18 & 9.90 \\
\hline $\mathrm{Na}_{2} \mathrm{O}$ & 3.66 & 2.55 & 2.22 & 3.18 & 2.71 & 2.97 & 0.59 & 5.29 & 4.36 & 3.20 & 3.34 \\
\hline $\mathrm{K}_{2} \mathrm{O}$ & 0.13 & 0.11 & 0.13 & 0.44 & 0.14 & 0.24 & 0.10 & 0.60 & 1.65 & 0.51 & 1.00 \\
\hline $\mathrm{P}_{2} \mathrm{O}_{5}$ & 0.17 & 0.25 & 0.04 & 0.19 & 0.11 & 0.06 & 0.00 & 0.04 & 0.45 & 0.04 & 0.90 \\
\hline LOI & 1.37 & 1.37 & 1.47 & 0.43 & 0.60 & 0.47 & 3.48 & 1.02 & 0.60 & 0.39 & 0.97 \\
\hline S & 0.01 & 0.01 & 0.02 & 0.01 & 0.02 & 0.01 & 0.01 & 0.01 & 0.01 & 0.01 & 0.08 \\
\hline Total & 99.41 & 99.68 & 100.36 & 100.56 & 99.74 & 99.73 & 100.51 & 100.11 & 99.40 & 99.58 & 99.60 \\
\hline
\end{tabular}

\begin{tabular}{|c|c|c|c|c|c|c|c|c|c|c|c|}
\hline $\mathrm{Ba}$ & 50 & 11 & 22 & 21 & 24 & 21 & 29 & 256 & 1285 & 193 & 393 \\
\hline $\mathrm{Cl}$ & 174 & 193 & 147 & 49 & 54 & 46 & 250 & 76 & 187 & 194 & 941 \\
\hline Co & 0 & 0 & 34 & 41 & 0 & 0 & 42 & 0 & 0 & 0 & 34 \\
\hline $\mathrm{Cr}$ & 198 & 171 & 599 & 378 & 465 & 329 & 200 & 67 & 155 & 261 & 131 \\
\hline Cs & 0.00 & 0.00 & 1.17 & 0.03 & 0.00 & 0.00 & 0.09 & 0.00 & 0.00 & 0.00 & 1.49 \\
\hline $\mathrm{Cu}$ & 30 & 31 & 70 & 66 & 102 & 43 & 116 & 20 & 66 & 38 & 80 \\
\hline $\mathrm{Ga}$ & 18 & 22 & 14 & 19 & 15 & 17 & 14 & 17 & 21 & 14 & 24 \\
\hline $\mathrm{Hf}$ & 0.00 & 0.00 & 0.49 & 2.00 & 0.00 & 0.00 & 0.20 & 0.00 & 0.00 & 0.00 & 1.45 \\
\hline $\mathrm{Nb}$ & 8.0 & 10.0 & 0.8 & 4.4 & 4.0 & 7.0 & 0.1 & 1.0 & 19.0 & 6.0 & 6.2 \\
\hline $\mathrm{Ni}$ & 47 & 26 & 121 & 64 & 85 & 88 & 104 & 30 & 28 & 256 & 12 \\
\hline $\mathrm{Pb}$ & 3 & 5 & 2 & 1 & 3 & 9 & 5 & 0 & 3 & 2 & 6 \\
\hline $\mathrm{Rb}$ & 1 & 2 & 2 & 0 & 0 & 1 & 2 & 9 & 28 & 1 & 21 \\
\hline $\mathrm{Sc}$ & 0 & 0 & 31 & 36 & 0 & 0 & 42 & 0 & 0 & 0 & 17 \\
\hline $\mathrm{Sr}$ & 191 & 185 & 114 & 267 & 360 & 204 & 322 & 976 & 655 & 353 & 882 \\
\hline $\mathrm{Ta}$ & 0.00 & 0.00 & 0.06 & 0.32 & 0.00 & 0.00 & 0.00 & 0.00 & 0.00 & 0.00 & 0.35 \\
\hline Th & 0.0 & 2.0 & 0.7 & 0.1 & 1.0 & 0.0 & 0.1 & 0.0 & 3.0 & 2.0 & 2.0 \\
\hline U & 0.00 & 0.00 & 0.02 & 0.07 & 0.00 & 0.00 & 0.00 & 0.00 & 0.00 & 0.00 & 0.55 \\
\hline V & 285 & 465 & 155 & 242 & 235 & 251 & 258 & 20 & 76 & 102 & 244 \\
\hline$Y$ & 37 & 61 & 15 & 30 & 30 & 30 & 9 & 4 & 15 & 9 & 33 \\
\hline $\mathrm{Zn}$ & 70 & 46 & 57 & 82 & 77 & 94 & 40 & 29 & 67 & 88 & 85 \\
\hline $\mathrm{Zr}$ & 104 & 179 & 31 & 118 & 68 & 86 & 6 & 7 & 105 & 44 & 68 \\
\hline La & 5.0 & 3.0 & 1.3 & 6.0 & 1.0 & 1.0 & 0.3 & 1.0 & 13.0 & 0.0 & 28.4 \\
\hline $\mathrm{Ce}$ & 0.0 & 37.0 & 3.9 & 17.4 & 0.0 & 0.0 & 1.1 & 0.0 & 52.0 & 0.0 & 64.6 \\
\hline $\operatorname{Pr}$ & 0.00 & 0.00 & 0.73 & 2.88 & 0.00 & 0.00 & 0.27 & 0.00 & 0.00 & 0.00 & 9.10 \\
\hline $\mathrm{Nd}$ & 12.0 & 28.0 & 3.9 & 14.4 & 1.0 & 6.0 & 1.8 & 2.0 & 33.0 & 7.0 & 38.9 \\
\hline $\mathrm{Sm}$ & 0.00 & 0.00 & 1.39 & 4.12 & 0.00 & 0.00 & 0.77 & 0.00 & 0.00 & 0.00 & 7.97 \\
\hline $\mathrm{Eu}$ & 0.00 & 0.00 & 0.65 & 1.38 & 0.00 & 0.00 & 0.40 & 0.00 & 0.00 & 0.00 & 1.98 \\
\hline $\mathrm{Gd}$ & 0.00 & 0.00 & 2.08 & 5.00 & 0.00 & 0.00 & 1.20 & 0.00 & 0.00 & 0.00 & 7.32 \\
\hline $\mathrm{Tb}$ & 0.00 & 0.00 & 0.38 & 0.88 & 0.00 & 0.00 & 0.20 & 0.00 & 0.00 & 0.00 & 1.08 \\
\hline Dy & 0.00 & 0.00 & 2.41 & 5.31 & 0.00 & 0.00 & 1.29 & 0.00 & 0.00 & 0.00 & 5.99 \\
\hline Ho & 0.00 & 0.00 & 0.52 & 1.13 & 0.00 & 0.00 & 0.28 & 0.00 & 0.00 & 0.00 & 1.19 \\
\hline $\mathrm{Er}$ & 0.00 & 0.00 & 1.41 & 2.98 & 0.00 & 0.00 & 0.75 & 0.00 & 0.00 & 0.00 & 3.07 \\
\hline $\mathrm{Tm}$ & 0.00 & 0.00 & 0.22 & 0.48 & 0.00 & 0.00 & 0.11 & 0.00 & 0.00 & 0.00 & 0.45 \\
\hline $\mathrm{Yb}$ & 0.00 & 0.00 & 1.34 & 2.85 & 0.00 & 0.00 & 0.66 & 0.00 & 0.00 & 0.00 & 2.61 \\
\hline Lu & 0.00 & 0.00 & 0.21 & 0.45 & 0.00 & 0.00 & 0.10 & 0.00 & 0.00 & 0.00 & 0.40 \\
\hline
\end{tabular}




\begin{tabular}{|c|c|c|c|c|c|c|c|c|c|c|}
\hline \multirow[t]{2}{*}{ Sample } & $03 \backslash 70$ & $03 \backslash 72$ & 03175 & 03177 & 03179 & $03 \backslash 80$ & 03164 & $03 \backslash 71$ & 03174 & 03176 \\
\hline & RestMB & RestMB & E-IAT & E-IAT & E-IAT & E-IAT & plaggr & plaggr & plaggr & plaggr \\
\hline $\mathrm{SiO} 2$ & 45.21 & 56.62 & 54.38 & 50.50 & 47.92 & 49.15 & 77.57 & 73.06 & 73.12 & 60.97 \\
\hline TiO2 & 1.87 & 0.28 & 0.60 & 0.46 & 1.06 & 0.95 & 0.25 & 0.28 & 0.08 & 0.41 \\
\hline $\mathrm{Al} 2 \mathrm{O} 3$ & 13.84 & 24.41 & 14.77 & 14.54 & 14.97 & 15.14 & 11.75 & 14.86 & 15.05 & 14.04 \\
\hline $\mathrm{Fe} 2 \mathrm{O} 3 \mathrm{~T}$ & 12.19 & 1.56 & 11.76 & 11.95 & 12.13 & 11.26 & 1.57 & 1.63 & 0.72 & 7.98 \\
\hline $\mathrm{MnO}$ & 0.13 & 0.01 & 0.21 & 0.21 & 0.23 & 0.19 & 0.02 & 0.01 & 0.01 & 0.15 \\
\hline $\mathrm{MgO}$ & 11.75 & 0.37 & 4.77 & 6.63 & 8.72 & 8.65 & 0.70 & 0.90 & 0.00 & 3.55 \\
\hline $\mathrm{CaO}$ & 10.16 & 8.87 & 9.35 & 11.24 & 11.20 & 10.98 & 0.87 & 3.16 & 0.90 & 7.76 \\
\hline $\mathrm{Na} 2 \mathrm{O}$ & 2.16 & 5.96 & 2.44 & 1.59 & 2.86 & 2.80 & 4.23 & 4.49 & 6.80 & 2.44 \\
\hline $\mathrm{K} 2 \mathrm{O}$ & 1.31 & 0.59 & 0.30 & 0.15 & 0.28 & 0.23 & 2.36 & 0.73 & 2.69 & 0.36 \\
\hline P2O5 & 0.04 & 0.08 & 0.06 & 0.04 & 0.10 & 0.09 & 0.04 & 0.03 & 0.03 & 0.08 \\
\hline LOI & 1.47 & 0.54 & 0.70 & 2.28 & 0.54 & 0.51 & 0.50 & 0.41 & 0.32 & 2.06 \\
\hline S & 0.01 & 0.01 & 0.03 & 0.01 & 0.01 & 0.01 & 0.01 & 0.01 & 0.01 & 0.03 \\
\hline Total & 100.14 & 99.31 & 99.38 & 99.61 & 100.02 & 99.95 & 99.87 & 99.58 & 99.74 & 99.82 \\
\hline
\end{tabular}

\begin{tabular}{|c|c|c|c|c|c|c|c|c|c|c|c|}
\hline $\mathrm{Ba}$ & 430 & 487 & 144 & 48 & 73 & 59 & 486 & 595 & 2109 & 69 & 35 \\
\hline $\mathrm{Cl}$ & 543 & 109 & 294 & 218 & 310 & 20 & 73 & 222 & 37 & 106 & 109 \\
\hline Co & 0 & 0 & 0 & 40 & 46 & 0 & 0 & 0 & 1 & 0 & 6 \\
\hline $\mathrm{Cr}$ & 92 & 83 & 158 & 195 & 301 & 238 & 163 & 120 & 80 & 165 & 96 \\
\hline Cs & 0.00 & 0.00 & 0.00 & 0.17 & 0.09 & 0.00 & 0.00 & 0.00 & 0.46 & 0.00 & 0.14 \\
\hline $\mathrm{Cu}$ & 68 & 18 & 97 & 73 & 56 & 63 & 18 & 10 & 16 & 70 & 15 \\
\hline $\mathrm{Ga}$ & 18 & 23 & 15 & 14 & 15 & 14 & 12 & 13 & 16 & 13 & 16 \\
\hline $\mathrm{Hf}$ & 0.00 & 0.00 & 0.00 & 0.35 & 0.35 & 0.00 & 0.00 & 0.00 & 0.49 & 0.00 & 0.06 \\
\hline $\mathrm{Nb}$ & 7.0 & 0.0 & 5.0 & 0.7 & 0.9 & 4.0 & 8.0 & 0.0 & 4.6 & 2.0 & 0.8 \\
\hline $\mathrm{Ni}$ & 13 & 6 & 24 & 38 & 81 & 68 & 11 & 9 & 7 & 20 & 9 \\
\hline $\mathrm{Pb}$ & 5 & 0 & 6 & 2 & 7 & 5 & 15 & 4 & 18 & 4 & 1 \\
\hline $\mathrm{Rb}$ & 21 & 1 & 4 & 2 & 1 & 1 & 35 & 23 & 36 & 13 & 1 \\
\hline $\mathrm{Sc}$ & 0 & 0 & 0 & 46 & 35 & 0 & 0 & 0 & 1 & 0 & 2 \\
\hline $\mathrm{Sr}$ & 611 & 1045 & 159 & 118 & 178 & 187 & 85 & 742 & 1027 & 126 & 404 \\
\hline Ta & 0.00 & 0.00 & 0.00 & 0.04 & 0.06 & 0.00 & 0.00 & 0.00 & 0.22 & 0.00 & 0.03 \\
\hline Th & 1.0 & 0.0 & 4.0 & 0.3 & 0.4 & 4.0 & 18.0 & 13.0 & 0.5 & 4.0 & 0.1 \\
\hline U & 0.00 & 0.00 & 0.00 & 0.09 & 0.11 & 0.00 & 0.00 & 0.00 & 0.63 & 0.00 & 0.05 \\
\hline v & 447 & 18 & 262 & 305 & 278 & 278 & 28 & 53 & 17 & 289 & 40 \\
\hline Y & 29 & 2 & 16 & 15 & 19 & 18 & 25 & 1 & 3 & 11 & 4 \\
\hline$Z n$ & 70 & 21 & 94 & 88 & 108 & 80 & 36 & 22 & 18 & 64 & 33 \\
\hline $\mathrm{Zr}$ & 42 & 0 & 12 & 19 & 44 & 33 & 166 & 73 & 56 & 12 & 169 \\
\hline
\end{tabular}

\begin{tabular}{|c|c|c|c|c|c|c|c|c|c|c|c|}
\hline La & 7.0 & 1.0 & 1.0 & 2.5 & 3.3 & 3.0 & 22.0 & 24.0 & 2.8 & 0.0 & 4.8 \\
\hline $\mathrm{Ce}$ & 33.0 & 0.0 & 0.0 & 5.4 & 8.5 & 0.0 & 53.0 & 38.0 & 6.8 & 0.0 & 8.8 \\
\hline $\mathrm{Pr}$ & 0.00 & 0.00 & 0.00 & 0.87 & 1.45 & 0.00 & 0.00 & 0.00 & 0.92 & 0.00 & 1.07 \\
\hline $\mathrm{Nd}$ & 25.0 & 0.0 & 7.0 & 4.1 & 7.4 & 8.0 & 29.0 & 21.0 & 3.6 & 0.0 & 4.3 \\
\hline $\mathrm{Sm}$ & 0.00 & 0.00 & 0.00 & 1.27 & 2.22 & 0.00 & 0.00 & 0.00 & 0.80 & 0.00 & 0.76 \\
\hline $\mathrm{Eu}$ & 0.00 & 0.00 & 0.00 & 0.44 & 0.92 & 0.00 & 0.00 & 0.00 & 0.51 & 0.00 & 0.57 \\
\hline $\mathrm{Gd}$ & 0.00 & 0.00 & 0.00 & 1.79 & 2.98 & 0.00 & 0.00 & 0.00 & 0.72 & 0.00 & 0.65 \\
\hline $\mathrm{Tb}$ & 0.00 & 0.00 & 0.00 & 0.32 & 0.51 & 0.00 & 0.00 & 0.00 & 0.09 & 0.00 & 0.08 \\
\hline Dy & 0.00 & 0.00 & 0.00 & 2.08 & 3.12 & 0.00 & 0.00 & 0.00 & 0.50 & 0.00 & 0.44 \\
\hline $\mathrm{Ho}$ & 0.00 & 0.00 & 0.00 & 0.47 & 0.67 & 0.00 & 0.00 & 0.00 & 0.10 & 0.00 & 0.09 \\
\hline $\mathrm{Er}$ & 0.00 & 0.00 & 0.00 & 1.33 & 1.81 & 0.00 & 0.00 & 0.00 & 0.25 & 0.00 & 0.25 \\
\hline $\mathrm{Tm}$ & 0.00 & 0.00 & 0.00 & 0.22 & 0.29 & 0.00 & 0.00 & 0.00 & 0.04 & 0.00 & 0.04 \\
\hline $\mathrm{Yb}$ & 0.00 & 0.00 & 0.00 & 1.42 & 1.78 & 0.00 & 0.00 & 0.00 & 0.26 & 0.00 & 0.25 \\
\hline Lu & 0.00 & 0.00 & 0.00 & 0.24 & 0.28 & 0.00 & 0.00 & 0.00 & 0.04 & 0.00 & 0.04 \\
\hline
\end{tabular}




\begin{tabular}{|c|c|c|c|c|c|c|}
\hline \multirow[t]{3}{*}{ Sample } & Almacık & Almacık & Almacık & Almacık & Almacık & \multirow[t]{3}{*}{ Almacık } \\
\hline & Western & Western & Resthouse & Resthouse & Eastern & \\
\hline & $n=7$ & & $n=6$ & & $n=5$ & \\
\hline $\mathrm{SiO} 2$ & 48.35 & 1.39 & 51.44 & 4.43 & 50.12 & 2.56 \\
\hline TiO2 & 1.63 & 0.80 & 0.94 & 0.76 & 0.76 & 0.25 \\
\hline $\mathrm{Al} 2 \mathrm{O} 3$ & 14.84 & 1.23 & 18.90 & 5.03 & 15.09 & 0.56 \\
\hline $\mathrm{Fe} 2 \mathrm{O} 3 \mathrm{~T}$ & 11.13 & 2.41 & 7.95 & 4.70 & 11.69 & 0.38 \\
\hline $\mathrm{MnO}$ & 0.16 & 0.03 & 0.10 & 0.06 & 0.21 & 0.01 \\
\hline $\mathrm{MgO}$ & 7.69 & 1.58 & 5.20 & 4.63 & 7.49 & 1.76 \\
\hline $\mathrm{CaO}$ & 11.93 & 1.79 & 9.07 & 1.56 & 10.55 & 0.85 \\
\hline $\mathrm{Na} 2 \mathrm{O}$ & 2.88 & 0.51 & 4.05 & 1.42 & 1.97 & 1.12 \\
\hline $\mathrm{K} 2 \mathrm{O}$ & 0.20 & 0.13 & 0.94 & 0.46 & 0.75 & 1.14 \\
\hline P2O5 & 0.14 & 0.08 & 0.26 & 0.35 & 0.07 & 0.02 \\
\hline LOI & 0.95 & 0.50 & 0.83 & 0.40 & 1.08 & 0.76 \\
\hline S & & & & & & \\
\hline
\end{tabular}

Total

\begin{tabular}{|c|c|c|c|c|c|c|}
\hline $\mathrm{Ba}$ & 25 & 13 & 507 & 397 & 74 & 41 \\
\hline $\mathrm{Cl}$ & 111 & 68 & 342 & 338 & 211 & 133 \\
\hline Co & 41 & 0 & 34 & 0 & 0 & 0 \\
\hline $\mathrm{Cr}$ & 357 & 162 & 132 & 71 & 244 & 66 \\
\hline Cs & 0.00 & 0 & 1.50 & 0 & 0.00 & 0 \\
\hline $\mathrm{Cu}$ & 57 & 28 & 48 & 27 & 72 & 18 \\
\hline $\mathrm{Ga}$ & 18 & 3 & 20 & 4 & 15 & 1 \\
\hline $\mathrm{Hf}$ & 2.00 & 0.00 & 1.50 & 0.00 & 0.60 & 0.00 \\
\hline $\mathrm{Nb}$ & 6.1 & 2.7 & 6.5 & 6.8 & 4.1 & 2.1 \\
\hline $\mathrm{Ni}$ & 72 & 34 & 58 & 98 & 53 & 26 \\
\hline $\mathrm{Pb}$ & 4 & 3 & 3 & 3 & 5 & 2 \\
\hline $\mathrm{Rb}$ & 1 & 1 & 14 & 11 & 2 & 1 \\
\hline Sc & 36 & 0 & 17 & 0 & 38 & 0 \\
\hline $\mathrm{Sr}$ & 220 & 84 & 754 & 261 & 148 & 38 \\
\hline $\mathrm{Ta}$ & 0.30 & 0.00 & 0.40 & 0.00 & 0.00 & 0.00 \\
\hline Th & 0.7 & 0.8 & 1.3 & 1.2 & 1.8 & 2.1 \\
\hline U & 0.07 & 0.00 & 0.55 & 0.00 & 0.16 & 0.00 \\
\hline V & 272 & 104 & 151 & 167 & 278 & 17 \\
\hline Y & 34 & 15 & 15 & 13 & 16 & 2 \\
\hline $\mathrm{Zn}$ & 71 & 17 & 60 & 28 & 93 & 12 \\
\hline $\mathrm{Zr}$ & 98 & 50 & 44 & 39 & 26 & 13 \\
\hline La & 2.8 & 2.2 & 8.4 & 11.0 & 2.0 & 2.0 \\
\hline $\mathrm{Ce}$ & 9.1 & 15.4 & 24.9 & 29.1 & 2.1 & 4.7 \\
\hline $\mathrm{Pr}$ & 2.88 & 0.00 & 9.10 & 0.00 & 1.46 & 0.00 \\
\hline $\mathrm{Nd}$ & 10.9 & 9.9 & 17.7 & 16.8 & 5.0 & 3.2 \\
\hline $\mathrm{Sm}$ & 4.12 & 0.00 & 7.97 & 0.00 & 1.92 & 0.00 \\
\hline $\mathrm{Eu}$ & 1.38 & 0.00 & 1.98 & 0.00 & 0.68 & 0.00 \\
\hline $\mathrm{Gd}$ & 5.00 & 0.00 & 7.32 & 0.00 & 2.24 & 0.00 \\
\hline $\mathrm{Tb}$ & 0.88 & 0.00 & 1.08 & 0.00 & 0.39 & 0.00 \\
\hline Dy & 5.31 & 0.00 & 5.99 & 0.00 & 2.57 & 0.00 \\
\hline Ho & 1.13 & 0.00 & 1.19 & 0.00 & 0.53 & 0.00 \\
\hline $\mathrm{Er}$ & 2.98 & 0.00 & 3.07 & 0.00 & 1.44 & 0.00 \\
\hline $\mathrm{Tm}$ & 0.48 & 0.00 & 0.45 & 0.00 & 0.21 & 0.00 \\
\hline $\mathrm{Yb}$ & 2.85 & 0.00 & 2.61 & 0.00 & 1.28 & 0.00 \\
\hline Lu & 0.45 & 0.00 & 0.40 & 0.00 & 0.18 & 0.00 \\
\hline
\end{tabular}


Table 3

4

5

\begin{tabular}{|c|c|c|c|c|c|c|c|c|c|}
\hline $\begin{array}{l}\text { Sample and } \\
\text { zircon grains } \\
(\mathrm{a}, \mathrm{b}, \mathrm{c}, \mathrm{d}, \mathrm{e}= \\
\text { temp. Step) }\end{array}$ & Zircon features & $\begin{array}{l}\text { Evap. } \\
\text { temp. } \\
{ }^{\circ} \mathrm{C}\end{array}$ & $\begin{array}{l}\text { No. of } \\
\text { ratios }\end{array}$ & $\begin{array}{l}\text { Th/U } \\
\text { ratio }\end{array}$ & $\begin{array}{l}{ }^{206} \mathrm{~Pb} /{ }^{208} \mathrm{~Pb} \\
\text { ratio }\end{array}$ & $\begin{array}{l}{ }^{204} \mathrm{~Pb} /{ }^{206} \mathrm{~Pb} \\
\text { ratio }\end{array}$ & $\begin{array}{l}{ }^{207} \mathrm{~Pb} /{ }^{206} \mathrm{~Pb} \\
\text { isotope ratio } \\
2 \sigma \text { error }\end{array}$ & $\begin{array}{l}{ }^{207} \mathrm{~Pb} /{ }^{206} \mathrm{~Pb} \\
\text { date }(\mathrm{Ma}) \\
2 \sigma \text { error }\end{array}$ & $\begin{array}{c}{ }^{207} \mathrm{~Pb} /{ }^{206} \mathrm{~Pb} \\
\text { date }(\mathrm{Ma}) \\
\text { treated } 1 \sigma \mathrm{SD} \\
\text { error } \\
\end{array}$ \\
\hline \multicolumn{10}{|l|}{601} \\
\hline 60I-2a & 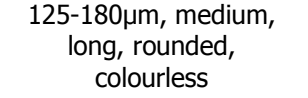 & 1380 & 48 & 0.66 & 6.59 & 0.001539 & $0.050908 \pm 233$ & $236.7 \pm 10.7$ & $236.7 \pm 11.0$ \\
\hline 60I-3a & $\begin{array}{l}125-180 \mu \mathrm{m} \text {, thick, long, } \\
\text { rounded, colourless }\end{array}$ & 1380 & 156 & 0.74 & 4.46 & 0.000264 & $0.050954 \pm 159$ & $238.8 \pm 7.8$ & $238.8 \pm 8.1$ \\
\hline $60 I-4 a$ & $\begin{array}{l}125-180 \mu m \text {, thick, long, } \\
\text { rounded, colourless }\end{array}$ & 1400 & 259 & 0.31 & 10.72 & 0.000264 & $0.050932 \pm 070$ & $237.8 \pm 3.2$ & $237.8 \pm 4.0$ \\
\hline 60I-5a & $\begin{array}{l}125-180 \mu m \text {, thick, short, } \\
\text { prismatic, colourless }\end{array}$ & 1400 & 316 & 0.24 & 14.21 & 0.000155 & $0.049395 \pm 058$ & $166.7 \pm 2.8$ & $166.7 \pm 3.6$ \\
\hline 60I-6a & $\begin{array}{l}125-180 \mu m \text {, thick, short, } \\
\text { rounded, colourless }\end{array}$ & 1400 & 287 & 0.63 & 5.26 & 0.000168 & $0.051018 \pm 046$ & $241.7 \pm 2.1$ & $241.7 \pm 3.1$ \\
\hline 60I-7a & $\begin{array}{l}125-180 \mu m \text {, thick, short, } \\
\text { rounded, colourless }\end{array}$ & 1400 & 453 & 0.15 & 22.36 & 0.000033 & $0.050839 \pm 021$ & $233.6 \pm 0.9$ & $233.6 \pm 2.5$ \\
\hline 60I-8a & $\begin{array}{l}125-180 \mu \mathrm{m}, \text { long, } \\
\text { prismatic, colourless }\end{array}$ & 1400 & 217 & 0.74 & 4.53 & 0.000422 & $0.051072 \pm 066$ & $244.1 \pm 3.0$ & $244.1 \pm 3.8$ \\
\hline 60I-9a & $\begin{array}{l}125-180 \mu \mathrm{m} \text {, long, thick, } \\
\text { prismatic, colourless }\end{array}$ & 1400 & 137 & 0.57 & 5.69 & 0.000161 & $0.050705 \pm 051$ & $227.5 \pm 2.3$ & $227.5 \pm 3.3$ \\
\hline 60I-10a & $\begin{array}{l}125-180 \mu \mathrm{m} \text {, long, thick, } \\
\text { prismatic, colourless }\end{array}$ & 1400 & 97 & 0.15 & 32.30 & 0.000403 & $0.050752 \pm 152$ & $230.4 \pm 6.6$ & $230.4 \pm 7.0$ \\
\hline $60 \mathrm{I}-11$ & $\begin{array}{l}125-180 \mu \mathrm{m} \\
\text { xenomorphic, colourless }\end{array}$ & 1400 & 279 & 0.38 & 8.61 & 0.000171 & $0.050976 \pm 066$ & $239.8 \pm 3.0$ & $239.8 \pm 3.8$ \\
\hline $60 I-12 a$ & \multirow{2}{*}{$\begin{array}{c}125-180 \mu \mathrm{m}, \\
\text { xenomorphic, colourless }\end{array}$} & 1400 & 86 & 0.78 & 4.16 & 0.000148 & $0.049550 \pm 073$ & $174.0 \pm 3.4$ & $174.0 \pm 4.1$ \\
\hline $60 I-12 b$ & & 1420 & 165 & 0.78 & 4.16 & 0.000148 & $0.050882 \pm 068$ & $235.5 \pm 3.1$ & $235.5 \pm 3.9$ \\
\hline $60 \mathrm{I}-13$ & $\begin{array}{c}125-180 \mu \mathrm{m}, \\
\text { xenomorphic, colourless }\end{array}$ & 1400 & 375 & 0.66 & 4.87 & 0.000091 & $0.051283 \pm 028$ & $253.6 \pm 1.2$ & $253.6 \pm 2.6$ \\
\hline \multicolumn{10}{|l|}{ 61I } \\
\hline 61I-1a & \multirow[t]{2}{*}{$\begin{array}{l}125-180 \mu \mathrm{m}, \text { long- } \\
\text { slender, xenomorphic, } \\
\text { colourless }\end{array}$} & 1380 & 55 & 0.84 & 3.80 & 0.000169 & $0.049294 \pm 306$ & $161.9 \pm 14.2$ & $161.9 \pm 14.4$ \\
\hline $\begin{array}{l}61 \mathrm{I}-1 \mathrm{~b} \\
\text { mean }\end{array}$ & & 1400 & $\begin{array}{c}27 \\
114\end{array}$ & $\begin{array}{l}0.52 \\
0.68\end{array}$ & $\begin{array}{l}6.21 \\
5.01\end{array}$ & $\begin{array}{l}0.000139 \\
0.000154\end{array}$ & $\begin{array}{l}0.049490 \pm 339 \\
0.049349 \pm 174\end{array}$ & $\begin{array}{c}171.1 \pm 11.4 \\
164.5 \pm 8.4\end{array}$ & $\begin{array}{l}171.1 \pm 11.6 \\
164.5 \pm 8.7\end{array}$ \\
\hline $61 \mathrm{I}-2 \mathrm{a}$ & \multirow[t]{2}{*}{$\begin{array}{l}125-180 \mu \mathrm{m}, \text { tiny, } \\
\text { prismatic, colourless }\end{array}$} & 1380 & 136 & 0.29 & 3.47 & 0.000179 & $0.050452 \pm 093$ & $215.9 \pm 4.3$ & $215.9 \pm 4.9$ \\
\hline $61 \mathrm{I}-2 \mathrm{~b}$ & & 1400 & 116 & 0.42 & 7.85 & 0.000113 & $0.051336 \pm 105$ & $256.0 \pm 4.8$ & $256.0 \pm 5.2$ \\
\hline 61I-3a & \multirow[t]{2}{*}{$\begin{array}{l}125-180 \mu \mathrm{m}, \text { tiny, } \\
\text { prismatic, colourless }\end{array}$} & 1380 & 108 & 0.16 & 19.46 & 0.000029 & $0.049311 \pm 061$ & $162.7 \pm 2.9$ & $162.7 \pm 3.7$ \\
\hline $\begin{array}{l}61 \mathrm{I}-3 \mathrm{~b} \\
\text { mean }\end{array}$ & & 1400 & $\begin{array}{c}75 \\
189\end{array}$ & $\begin{array}{l}0.16 \\
0.16\end{array}$ & $\begin{array}{l}19.72 \\
19.57\end{array}$ & $\begin{array}{l}0.000030 \\
0.000029\end{array}$ & $\begin{array}{l}0.049380 \pm 148 \\
0.049354 \pm 071\end{array}$ & $\begin{array}{c}166.0 \pm 7.1 \\
\mathbf{1 6 4 . 7} \pm \mathbf{3 . 4}\end{array}$ & $\begin{array}{r}166.0 \pm 7.5 \\
\mathbf{1 6 4 . 7} \pm \mathbf{4 . 1}\end{array}$ \\
\hline $61 \mathrm{I}-4$ & $\begin{array}{c}125-180 \mu \mathrm{m} \\
\text { xenomorphic, colourless }\end{array}$ & 1380 & 91 & 0.18 & 21.23 & 0.000229 & $0.050506 \pm 169$ & $218.4 \pm 7.8$ & $218.4 \pm 8.2$ \\
\hline $61 \mathrm{I}-5$ & $\begin{array}{l}125-180 \mu \mathrm{m} \\
\text { xenomorphic, colourless }\end{array}$ & 1380 & 442 & 0.53 & 6.05 & 0.000026 & $0.051103 \pm 024$ & $245.5 \pm 1.1$ & $245.5 \pm 2.6$ \\
\hline $61 \mathrm{I}-7$ & $\begin{array}{l}125-180 \mu \mathrm{m}, \text { tiny, } \\
\text { prismatic, colourless }\end{array}$ & 1380 & 138 & 0.18 & 22.29 & 0.000223 & $0.049269 \pm 088$ & $160.7 \pm 4.2$ & $160.7 \pm 4.8$ \\
\hline \multicolumn{10}{|l|}{6} \\
\hline $65-1 a$ & 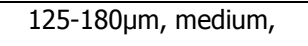 & 1380 & 183 & 0.50 & 6.72 & 0.000032 & $0.055451 \pm 066$ & $430.5 \pm 2.7$ & $430.5 \pm 3.5$ \\
\hline
\end{tabular}




\begin{tabular}{|c|c|c|c|c|c|c|c|c|c|}
\hline & prismatic, colourless & & & & & & & & \\
\hline $\begin{array}{l}65-1 b \\
\text { mean }\end{array}$ & & 1400 & $\begin{array}{l}178 \\
382\end{array}$ & $\begin{array}{l}0.54 \\
0.52\end{array}$ & $\begin{array}{l}5.96 \\
6.37\end{array}$ & $\begin{array}{l}0.000021 \\
0.000027\end{array}$ & $\begin{array}{l}0.055454 \pm 066 \\
0.055485 \pm 052\end{array}$ & $\begin{array}{l}430.6 \pm 2.7 \\
430.6 \pm 2.1\end{array}$ & $\begin{array}{l}430.6 \pm 3.5 \\
430.6 \pm 3.1\end{array}$ \\
\hline $65-2$ & $\begin{array}{l}125-180 \mu \mathrm{m} \text {, long, } \\
\text { slender, yellow }\end{array}$ & 1380 & 167 & 0.31 & 10.45 & 0.000096 & $0.052909 \pm 066$ & $324.9 \pm 2.8$ & $324.9 \pm 3.7$ \\
\hline $65-3 a$ & \multirow{2}{*}{$\begin{array}{l}125-180 \mu \mathrm{m}, \text { medium, } \\
\text { prismatic, colourless }\end{array}$} & 1380 & 254 & 0.38 & 8.92 & 0.000045 & $0.103907 \pm 094$ & $1695.1 \pm 1.7$ & $1695.1 \pm 2.3$ \\
\hline $65-3 b$ & & 1400 & 211 & 0.56 & 6.22 & 0.000045 & $0.158768 \pm 312$ & $2442.6 \pm 2.3$ & $2442.6 \pm 2.8$ \\
\hline $65-4 a$ & \multirow[t]{2}{*}{$\begin{array}{l}125-180 \mu \mathrm{m}, \text { medium, } \\
\text { prismatic, colourless }\end{array}$} & 1380 & 74 & 0.084 & 38.16 & 0.000009 & $0.053319 \pm 089$ & $342.4 \pm 3.8$ & $342.4 \pm 4.4$ \\
\hline $\begin{array}{c}65-4 b \\
65-4 a b \text { mean }\end{array}$ & & 1400 & $\begin{array}{l}147 \\
226\end{array}$ & $\begin{array}{l}0.087 \\
0.086\end{array}$ & $\begin{array}{l}37.17 \\
37.50\end{array}$ & $\begin{array}{l}0.000015 \\
0.000013\end{array}$ & $\begin{array}{l}0.053030 \pm 041 \\
0.053123 \pm 046\end{array}$ & $\begin{array}{l}330.1 \pm 1.7 \\
334.1 \pm 2.0\end{array}$ & $\begin{array}{l}330.1 \pm 2.9 \\
334.1 \pm 3.0\end{array}$ \\
\hline $65-5$ & $\begin{array}{c}125-180 \mu m \text {, prismatic, } \\
\text { colourless }\end{array}$ & 1380 & 365 & 0.49 & 6.56 & 0.000029 & $0.052217 \pm 032$ & $295.0 \pm 1.4$ & $295.0 \pm 2.7$ \\
\hline $65-6 a$ & \multirow{2}{*}{$\begin{array}{c}125-180 \mu m \text { prismatic, } \\
\text { colourless }\end{array}$} & 1380 & 150 & 0.51 & 6.37 & 0.000112 & $0.051900 \pm 071$ & $281.0 \pm 3.1$ & $281.0 \pm 3.9$ \\
\hline $65-6 b$ & & 1400 & 259 & 0.51 & 6.37 & 0.000112 & $0.056634 \pm 047$ & $477.3 \pm 1.8$ & $477.3 \pm 2.9$ \\
\hline
\end{tabular}




\section{Table 4}

\begin{tabular}{|c|c|c|c|c|c|c|c|c|c|c|c|c|c|c|c|c|c|c|c|}
\hline \multirow{2}{*}{5 Analysis } & \multicolumn{3}{|c|}{ Signal Intensities (mV) } & \multicolumn{2}{|c|}{ entrations ( } & \multicolumn{7}{|c|}{ Ratios } & \multicolumn{6}{|c|}{ Ages (Ma) } & \multirow[t]{2}{*}{$\%$ disc } \\
\hline & ${ }^{206} \mathrm{~Pb}$ & ${ }^{20 /} \mathrm{Pb}$ & ${ }^{238} \mathrm{U}$ & $\mathrm{Pb}$ & $\mathrm{U}^{*}$ & ${ }^{20 /} \mathrm{Pb} /{ }^{206} \mathrm{~Pb}$ & $\pm 1 \mathrm{~s} \%$ & ${ }^{206} \mathrm{~Pb} /{ }^{23 \gamma} \mathrm{U}$ & $\pm 1 \mathrm{~s} \%$ & ${ }^{20 /} \mathrm{Pb} /{ }^{230} \mathrm{U}$ & $\pm 1 \mathrm{~s} \%$ & Rho & ${ }^{20 /} \mathrm{Pb} /{ }^{206} \mathrm{~Pb}$ & $\pm 2 \mathrm{~s}$ abs & ${ }^{206} \mathrm{~Pb} /{ }^{238} \mathrm{U}$ & $\pm 2 \mathrm{~s}$ abs & ${ }^{20 /} \mathrm{Pb} /{ }^{235} \mathrm{U}$ & $\pm 2 \mathrm{~s}$ abs & \\
\hline & 0.48 & 0.02 & 16.69 & 2 & 50 & 0.0535 & 3.8 & 0.0405 & 1.0 & 0.2989 & 3.9 & 0.27 & 349.1 & 170.2 & 256.2 & 5.4 & 265.5 & 23.4 & 27 \\
\hline 42A_Z1_2_CORE & 0.50 & 0.02 & 17.57 & 2 & 53 & 0.0525 & 3.6 & 0.0406 & 1.0 & 0.2939 & 3.8 & 0.27 & 308.6 & 164.9 & 256.4 & 5.3 & 261.7 & 22.2 & 17 \\
\hline 8 42A_Z1_3_RIM & 1.45 & 0.06 & 77.09 & 6 & 232 & 0.0502 & 1.5 & 0.0262 & 1.1 & 0.1811 & 1.8 & 0.57 & 204.5 & 69.6 & 166.4 & 3.5 & 169.0 & 6.7 & 19 \\
\hline 9 42A_Z1_4_RIM & 1.78 & 0.08 & 81.19 & 7 & 244 & 0.0500 & 1.2 & 0.0308 & 1.1 & 0.2125 & 1.6 & 0.66 & 194.3 & 55.9 & 195.8 & 4.2 & 195.7 & 6.9 & -1 \\
\hline 102A_Z2_1_C & 0.54 & 0.02 & 18.26 & 2 & 55 & 0.0514 & 3.4 & 0.0411 & 1.1 & 0.2911 & 3.5 & 0.30 & 258.1 & 154.8 & 259.6 & 5.6 & 259.4 & 20.7 & -1 \\
\hline 142A_Z3_1_50 MIC 60PC & 1.10 & 0.05 & 38.03 & 4 & 114 & 0.0522 & 1.8 & 0.0404 & 1.1 & 0.2907 & 2.1 & 0.50 & 292.7 & 84.0 & 255.4 & 5.6 & 259.1 & 12.5 & 13 \\
\hline 1242A_Z4_1_50 MIC 60PC & 3.81 & 0.17 & 138.80 & 15 & 417 & 0.0516 & 0.6 & 0.0390 & 1.1 & 0.2775 & 1.2 & 0.87 & 268.2 & 27.8 & 246.6 & 5.5 & 248.6 & 7.0 & 8 \\
\hline 132A_Z4_2_50 MIC 60PC & 0.76 & 0.03 & 26.87 & 3 & 81 & 0.0527 & 2.4 & 0.0399 & 1.1 & 0.2898 & 2.7 & 0.42 & 315.2 & 110.3 & 252.2 & 5.8 & 258.4 & 15.6 & 20 \\
\hline 142A_Z5_1_50 MIC 60PC & 0.73 & 0.03 & 30.85 & 3 & 93 & 0.0511 & 2.6 & 0.0331 & 1.7 & 0.2336 & 3.1 & 0.55 & 245.7 & 117.8 & 210.2 & 7.1 & 213.1 & 14.4 & 14 \\
\hline 152A_Z5_2_50 MIC 60PC & 2.80 & 0.12 & 152.87 & 11 & 460 & 0.0498 & 0.8 & 0.0257 & 1.2 & 0.1767 & 1.5 & 0.83 & 185.6 & 38.2 & 163.8 & 4.0 & 165.2 & 5.2 & 12 \\
\hline 162A_Z6_2_50 MIC 60PC & 0.72 & 0.03 & 25.48 & 3 & 77 & 0.0519 & 2.6 & 0.0397 & 1.1 & 0.2841 & 2.8 & 0.40 & 279.4 & 117.5 & 251.2 & 5.7 & 253.9 & 16.0 & 10 \\
\hline 172A_Z7_1_C & 0.34 & 0.02 & 11.77 & 1 & 35 & 0.0519 & 4.9 & 0.0404 & 1.0 & 0.2889 & 5.0 & 0.21 & 279.3 & 225.8 & 255.3 & 5.4 & 257.7 & 29.1 & 9 \\
\hline 18 $2 \mathrm{~A}-\mathrm{Z7}{ }^{2} 2 \mathrm{R}$ & 0.55 & 0.02 & 22.85 & 2 & 69 & 0.0511 & 3.3 & 0.0343 & 1.2 & 0.2417 & 3.5 & 0.35 & 244.4 & 151.7 & 217.5 & 5.5 & 219.8 & 17.1 & 11 \\
\hline $19^{2 \mathrm{~A} Z \mathrm{Z} 8 \_1}$ & 1.17 & 0.05 & 41.50 & 5 & 125 & 0.0519 & 1.7 & 0.0400 & 1.1 & 0.2861 & 2.0 & 0.55 & 281.0 & 77.7 & 252.7 & 5.8 & 255.5 & 11.8 & 10 \\
\hline 20A_Z9_1_C & 0.76 & 0.03 & 27.03 & 3 & 81 & 0.0511 & 2.4 & 0.0403 & 1.0 & 0.2840 & 2.6 & 0.39 & 247.5 & 111.3 & 254.5 & 5.3 & 253.9 & 15.0 & -3 \\
\hline $2142 \mathrm{~A} Z \mathrm{Z} 9{ }_{2}$ _R & 1.20 & 0.05 & 42.22 & 5 & 127 & 0.0512 & 1.7 & 0.0403 & 1.2 & 0.2846 & 2.0 & 0.58 & 250.2 & 76.8 & 254.8 & 6.1 & 254.3 & 11.7 & -2 \\
\hline 2 $42 \mathrm{~A}$ Z9_3_R & 3.75 & 0.16 & 201.02 & 15 & 604 & 0.0500 & 0.6 & 0.0268 & 1.1 & 0.1843 & 1.3 & 0.87 & 193.6 & 29.4 & 170.2 & 3.8 & 171.8 & 4.7 & 12 \\
\hline $242 \mathrm{~A} Z \mathrm{Z} 10 \_3$ & 1.15 & 0.05 & 40.94 & 5 & 123 & 0.0510 & 1.8 & 0.0403 & 1.1 & 0.2834 & 2.1 & 0.54 & 242.7 & 82.2 & 254.5 & 6.0 & 253.3 & 12.1 & -5 \\
\hline 2344A_Z12_1_C & 0.91 & 0.04 & 31.87 & 4 & 96 & 0.0525 & 2.1 & 0.0404 & 1.0 & 0.2926 & 2.4 & 0.43 & 308.7 & 97.4 & 255.3 & 5.3 & 260.6 & 14.0 & 17 \\
\hline 24 2A_Z12_2 & 0.72 & 0.03 & 25.63 & 3 & 77 & 0.0521 & 2.6 & 0.0400 & 1.0 & 0.2873 & 2.8 & 0.38 & 289.1 & 116.6 & 252.9 & 5.4 & 256.4 & 16.0 & 13 \\
\hline 2542A_Z13_1_R & 2.63 & 0.12 & 93.45 & 11 & 281 & 0.0528 & 1.0 & 0.0397 & 1.0 & 0.2890 & 1.4 & 0.73 & 319.7 & 43.9 & 251.0 & 5.3 & 257.8 & 8.2 & 21 \\
\hline 262A_Z14_1 & 0.85 & 0.04 & 29.83 & 3 & 90 & 0.0521 & 2.2 & 0.0398 & 1.1 & 0.2862 & 2.5 & 0.43 & 290.1 & 102.5 & 251.9 & 5.5 & 255.6 & 14.4 & 13 \\
\hline 2742A_Z15_2 & 1.11 & 0.05 & 47.58 & 5 & 143 & 0.0506 & 1.8 & 0.0334 & 1.2 & 0.2329 & 2.2 & 0.57 & 222.4 & 83.2 & 211.7 & 5.3 & 212.6 & 10.3 & 5 \\
\hline 2\&2A_Z17_1 & 1.21 & 0.05 & 42.15 & 5 & 127 & 0.0515 & 1.6 & 0.0409 & 1.0 & 0.2902 & 1.9 & 0.53 & 263.3 & 75.5 & 258.2 & 5.4 & 258.7 & 11.4 & 2 \\
\hline 292A_Z18_2 & 0.66 & 0.03 & 22.75 & 3 & 68 & 0.0515 & 2.9 & 0.0411 & 1.0 & 0.2918 & 3.0 & 0.34 & 262.7 & 131.4 & 259.7 & 5.4 & 260.0 & 17.9 & 1 \\
\hline
\end{tabular}

2912A_Z18_2

3 * Accuracy of $\mathrm{U}$ concentration is c .20\%

32 Isotope ratios are not common $\mathrm{Pb}$ corrected

$33^{\%} \%$ Discordance is measured as ${ }^{206} \mathrm{~Pb}{ }^{238} \mathrm{U}$ age relative to ${ }^{207} \mathrm{~Pb} /{ }^{235} \mathrm{U}$ age for all spots

34
35
36
37
38
39
40
41
42
43
44
45
46
47
48


Table 5.

\begin{tabular}{|lcccccc|}
\hline Sample & $\mathbf{R b}[\mathbf{p p m}]$ & $\mathbf{S r}[\mathbf{p p m}]$ & ${ }^{\mathbf{8}} \mathbf{R b} /{ }^{\mathbf{8 6}} \mathbf{S r}$ & ${ }^{\mathbf{8 7}} \mathbf{S r} /{ }^{\mathbf{8 6}} \mathbf{S r}$ & Initial & Alter [Ma] \\
\hline 60-I WR & 26.71 & 931.9 & 0.0829 & $0.705921 \pm 09$ & & \\
60-I Biotite & 209.4 & 28.28 & 21.516 & $0.748335 \pm 08$ & $0.70576 \pm 21$ & $139 \pm 2$ \\
\hline
\end{tabular}

Sr-Standard: NBS 987 87Sr/86Sr: $0.710250 \pm 09$ 


\section{Page 43 of 56}

\section{Proof For Review}

Table 6.

Atomic ratios

calculated apparent ages $(\mathrm{Ma})$

\begin{tabular}{|c|c|c|c|c|c|c|c|c|c|c|c|c|c|c|c|}
\hline \multirow{2}{*}{$\begin{array}{l}\text { Sample/ } \\
\text { Sample } \\
\text { fraction }\end{array}$} & \multirow{2}{*}{$\begin{array}{l}\text { Sample } \\
\text { weight } \\
\text { in } \mathrm{mg}^{*}\end{array}$} & \multirow{2}{*}{$\begin{array}{c}\mathrm{U} \\
\text { (ppm) }\end{array}$} & \multirow{2}{*}{$\begin{array}{c}\text { Th } \\
\text { (ppm) }\end{array}$} & \multirow{2}{*}{$\frac{\mathrm{Th}}{\mathrm{U}}$} & \multirow{2}{*}{$\begin{array}{c}\mathrm{Pb} \\
(\mathrm{ppm})\end{array}$} & \multirow{2}{*}{$\frac{{ }^{208} \mathrm{~Pb}^{*}}{{ }^{206} \mathrm{~Pb}^{*}}$} & \multirow{2}{*}{$\frac{{ }^{206} \mathrm{~Pb}}{{ }^{238} \mathrm{U}}$} & \multirow{2}{*}{$\frac{{ }^{207} \mathrm{~Pb}}{{ }^{235} \mathrm{U}}$} & \multirow{2}{*}{$\begin{array}{l}\text { Correlation } \\
\text { coefficient }\end{array}$} & \multirow{2}{*}{$\frac{{ }^{208} \mathrm{~Pb}}{{ }^{232} \mathrm{Th}}$} & \multirow{2}{*}{$\frac{{ }^{207} \mathrm{~Pb}^{*}}{{ }^{206} \mathrm{~Pb}^{*}}$} & \multirow{2}{*}{$\frac{{ }^{206} \mathrm{~Pb}^{*}}{{ }^{238} \mathrm{U}}$} & \multirow{2}{*}{$\frac{{ }^{207} \mathrm{~Pb}^{*}}{{ }^{235} \mathrm{U}}$} & \multirow{2}{*}{$\frac{{ }^{208} \mathrm{~Pb}}{{ }^{232} \mathrm{Th}}$} & \multirow{2}{*}{$\frac{{ }^{207} \mathrm{~Pb}^{*}}{{ }^{206} \mathrm{~Pb}^{*}}$} \\
\hline & & & & & & & & & & & & & & & \\
\hline \multicolumn{16}{|c|}{ Sample 61I } \\
\hline 1 & 0.077 & 171.9 & 275.9 & 1.61 & 4.47 & 0.582848 & $0.0132 \pm 02$ & $0.1133 \pm 47$ & 0.99 & $0.0046 \pm 01$ & $0.0621 \pm 24$ & 84.7 & 108.9 & 93.7 & 678.9 \\
\hline 2 & 0.077 & 117.1 & 426.7 & 3.65 & 8.07 & 0.524768 & $0.0247 \pm 02$ & $0.1720 \pm 42$ & 0.98 & $0.0034 \pm 01$ & $0.0504 \pm 11$ & 159.5 & 161.2 & 69.5 & 215.0 \\
\hline 5 & 0.085 & 99.15 & 167.2 & 1.69 & 4.36 & 0.568011 & $0.0242 \pm 02$ & $0.1714 \pm 18$ & 0.99 & $0.0079 \pm 01$ & $0.0513 \pm 03$ & 154.3 & 160.8 & 158.9 & 255.4 \\
\hline 6 & 0.114 & 60.87 & 99.64 & 1.64 & 14.5 & 0.536423 & $0.0467 \pm 04$ & $0.3269 \pm 100$ & 0.98 & $0.0148 \pm 01$ & $0.0507 \pm 15$ & 294.5 & 287.3 & 297.5 & 228.6 \\
\hline
\end{tabular}

All errors quoted are $2 \sigma$ absolute uncertainties and refer to the last digit

* = radiogenic ; grain size varies from $80-180 \mu \mathrm{m}$

$\mathrm{mg}^{*}=$ error in weight is estimated to be up to $10 \%$ 
Table 7.

\begin{tabular}{|c|c|c|c|c|}
\hline Location & Method & Mineral/rock & Age (Ma) & Reference \\
\hline \multirow{2}{*}{$\begin{array}{l}\text { Refahiye } \\
\text { ophiolites }\end{array}$} & Ar-Ar & hornblende & $175 \pm 4 \& 173 \pm 4$ & \multirow{4}{*}{ Topuz, 2012} \\
\hline & $\mathrm{U}-\mathrm{Pb}$ & zircon & $186 \pm 4 \& 178 \pm 4$ & \\
\hline \multirow{2}{*}{$\begin{array}{c}\text { Refahiye } \\
\text { metamorphics }\end{array}$} & Ar-Ar & phengite & $174 \pm 4 \mathrm{Ma}$ & \\
\hline & $\mathrm{U}-\mathrm{Pb}$ & rutile & $183 \pm 7 \mathrm{Ma}$ & \\
\hline \multirow{5}{*}{$\begin{array}{l}\text { Daday- } \\
\text { Devrekani } \\
\text { Massif }\end{array}$} & \multirow{3}{*}{$\mathrm{K}-\mathrm{Ar}$} & hornblende & $170 \pm 10$ & \multirow{3}{*}{$\begin{array}{l}\text { Y1lmaz \& } \\
\text { Bonhomme, } \\
1991 \text { in Boztuğ } \\
\text { \& Y1lmaz, } 1995\end{array}$} \\
\hline & & biotite & $162 \pm 5$ to $149 \pm 4$ & \\
\hline & & mica & $\begin{array}{c}126 \pm 4 \text { and } \\
110 \pm 5\end{array}$ & \\
\hline & \multirow{2}{*}{$\mathrm{Ar}-\mathrm{Ar}$} & muscovite & $150 \pm 2$ to $141 \pm 2$ & \multirow{2}{*}{ Okay et al. 2010} \\
\hline & & biotite & $152 \pm 1$ to $149 \pm 1$ & \\
\hline $\begin{array}{l}\text { Devrekani } \\
\text { granites }\end{array}$ & $\mathrm{U}-\mathrm{Pb}$ & zircon & $\begin{array}{c}172.0 \pm 9.7 \text { to } \\
165.0 \pm 5.3\end{array}$ & Nzegge, 2008 \\
\hline $\begin{array}{c}\text { Çanğaldağ } \\
\text { metaophiolite }\end{array}$ & $\mathrm{K}-\mathrm{Ar}$ & amphibole & $\begin{array}{c}153 \pm 15 \text { and } \\
116 \pm 5\end{array}$ & $\begin{array}{c}\text { Boztuğ \& } \\
\text { Y1lmaz, } 1995\end{array}$ \\
\hline \multirow{3}{*}{$\begin{array}{l}\text { Kastamonu } \\
\text { granitoid }\end{array}$} & \multirow{3}{*}{$\mathrm{K}-\mathrm{Ar}$} & hornblende & $176 \pm 7$ & \multirow{3}{*}{$\begin{array}{c}\text { Yilmaz \& } \\
\text { Bonhomme, } \\
1991\end{array}$} \\
\hline & & Biotite & $162 \pm 5$ & \\
\hline & & K-feldispar & $134 \pm 6$ & \\
\hline \multirow{4}{*}{$\begin{array}{l}\text { Çele mafic } \\
\text { complex }\end{array}$} & $\mathrm{U}-\mathrm{Pb}$ & zircon & $\begin{array}{c}260 \pm 6 \\
\text { to } 249.7 \pm 3.9 \\
\end{array}$ & \multirow{4}{*}{$\begin{array}{l}\text { Bozkurt et al. } \\
2012\end{array}$} \\
\hline & $\mathrm{U}-\mathrm{Pb}$ & monazite & $\begin{array}{l}238 \pm 12 \text { to } \\
208.0 \pm 7.9 \\
\end{array}$ & \\
\hline & $\mathrm{K}-\mathrm{Ar}$ & hornblende & $\begin{array}{c}240.7 \pm 9.2 \text { to } \\
205.5 \pm 7.9\end{array}$ & \\
\hline & $\mathrm{Rb}-\mathrm{Sr}$ & biotite & $\begin{array}{c}161.8 \pm 1.7 \text { to } \\
153.7 \pm 1.6\end{array}$ & \\
\hline $\begin{array}{l}\text { Armutlu and } \\
\text { Almacik } \\
\text { complexes }\end{array}$ & Ar-Ar & amphibole & $220-160 \mathrm{Ma}$ & Çelik et al. 2009 \\
\hline \multirow{3}{*}{$\begin{array}{c}\text { metagranites in } \\
\text { the Armutlu } \\
\text { Peninsula }\end{array}$} & $\mathrm{U}-\mathrm{Pb}$ & zircon & $\begin{array}{c}179.3 \pm 1.8 \text { to } \\
158.8 \pm 1.6\end{array}$ & \multirow{5}{*}{$\begin{array}{c}\text { Akbayram et al. } \\
2012\end{array}$} \\
\hline & Sm-Nd & Garnet & $\begin{array}{c}156 \pm 12 \text { and } \\
157 \pm 18\end{array}$ & \\
\hline & $\mathrm{Rb}-\mathrm{Sr}$ & muscovite & $\begin{array}{c}179.3 \pm 1.8 \text { and } \\
158.8 \pm 1.6\end{array}$ & \\
\hline \multirow{2}{*}{$\begin{array}{c}\text { metasediments } \\
\text { in the Armutlu } \\
\text { Peninsula }\end{array}$} & \multirow{2}{*}{$\mathrm{Rb}-\mathrm{Sr}$} & muscovite & $\begin{array}{c}179.3 \pm 1.8 \text { to } \\
110.8 \pm 3.4\end{array}$ & \\
\hline & & bitotie & $\begin{array}{l}172 \pm 30 \text { to } \\
111.3 \pm 1.1\end{array}$ & \\
\hline HP rocks of & \multirow[b]{2}{*}{ Ar-Ar } & phengite & $203.1 \pm 2.9$ & \multirow[b]{2}{*}{$\begin{array}{c}\text { Okay \& Monie, } \\
1997\end{array}$} \\
\hline $\begin{array}{c}\text { Karakaya } \\
\text { Complex, } \\
\text { Armutlu } \\
\text { Peninsula }\end{array}$ & & amphibole & $164 \pm 17.1$ & \\
\hline \multirow{3}{*}{$\begin{array}{l}\text { HP rocks of } \\
\text { Karakaya } \\
\text { Complex, north } \\
\text { of Eskişehir }\end{array}$} & \multirow{3}{*}{ Ar-Ar } & phengite & $\begin{array}{c}214.9 \pm 2.7 \text { to } \\
203.4 \pm 3.4\end{array}$ & \multirow{3}{*}{ Okay et al. 2002} \\
\hline & & glaucophane & $204.8 \pm 4.7$ & \\
\hline & & barrosite & $209.7 \pm 4.2$ & \\
\hline
\end{tabular}




\begin{tabular}{|c|c|c|c|c|}
\hline \multirow{4}{*}{$\begin{array}{c}\text { Strandja Massif } \\
\text { granites }\end{array}$} & \multirow{4}{*}{$\mathrm{U}-\mathrm{Pb}$} & \multirow{4}{*}{ zircon } & $\sim 244$ & $\begin{array}{c}\text { A. Okay et al. } \\
1994\end{array}$ \\
\hline & & & 271 & $\begin{array}{c}\text { A. Okay et al. } \\
2001\end{array}$ \\
\hline & & & $257.0 \pm 6.2$ & Sunal et al. 2006 \\
\hline & & & 257 & Okay et al. 2008 \\
\hline \multirow{2}{*}{ Strandja Massif } & $\mathrm{Ar}-\mathrm{Ar}$ & \multirow{2}{*}{ mica } & 156.5 to 143.2 & $\begin{array}{c}\text { Elmas et al. } \\
2011\end{array}$ \\
\hline & $\mathrm{Rb}-\mathrm{Sr}$ & & $\begin{array}{c}162.9 \pm 1.6 \mathrm{Ma} \text { to } \\
149.1 \pm 2.1\end{array}$ & Sunal et al. 2011 \\
\hline $\begin{array}{c}\text { HP rocks in } \\
\text { Meliata suture }\end{array}$ & Ar-Ar & phengite & $160-150$ & $\begin{array}{c}\text { Dallmeyer et al. } \\
2008\end{array}$ \\
\hline & & & & \\
\hline
\end{tabular}




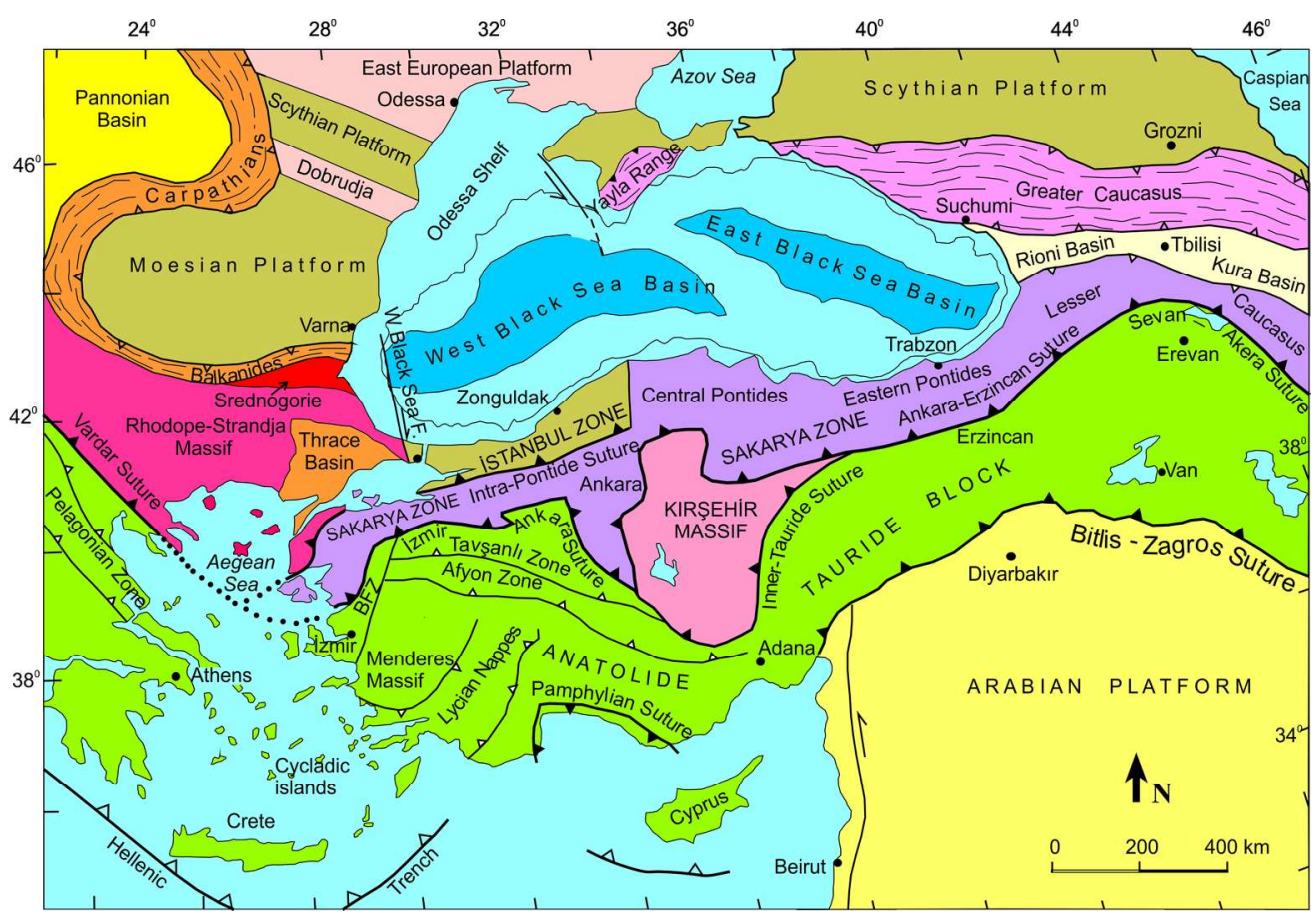

$174 \times 119 \mathrm{~mm}(300 \times 300$ DPI $)$ 


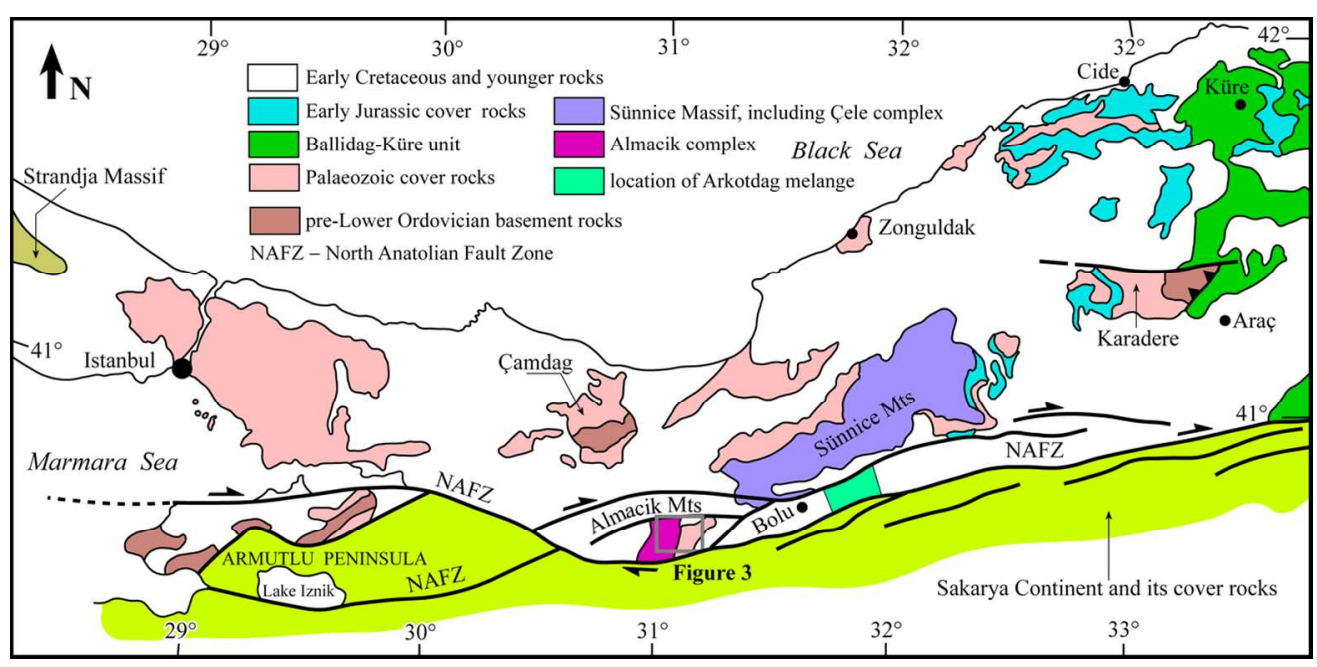

$121 \times 59 \mathrm{~mm}(300 \times 300 \mathrm{DPI})$ 


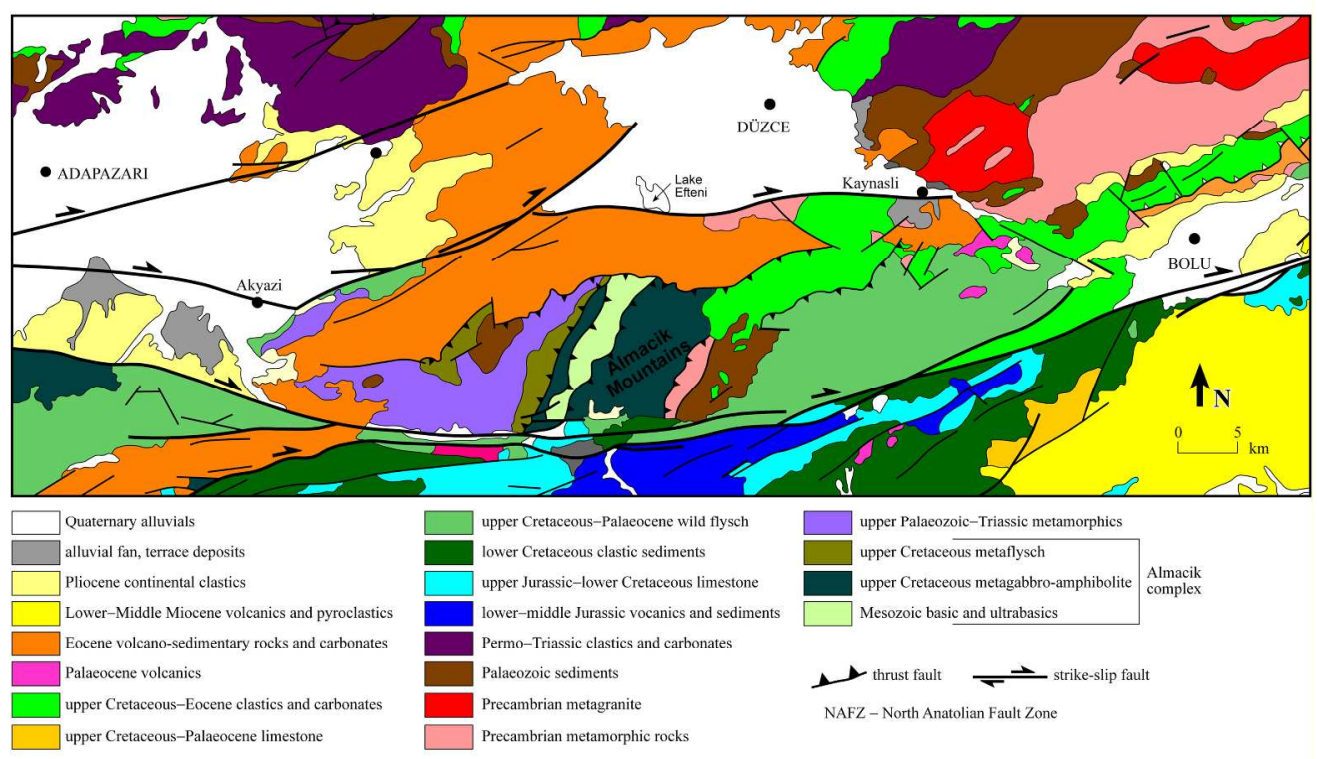






Figure 4

$94 \times 47 \mathrm{~mm}(300 \times 300 \mathrm{DPI})$ 

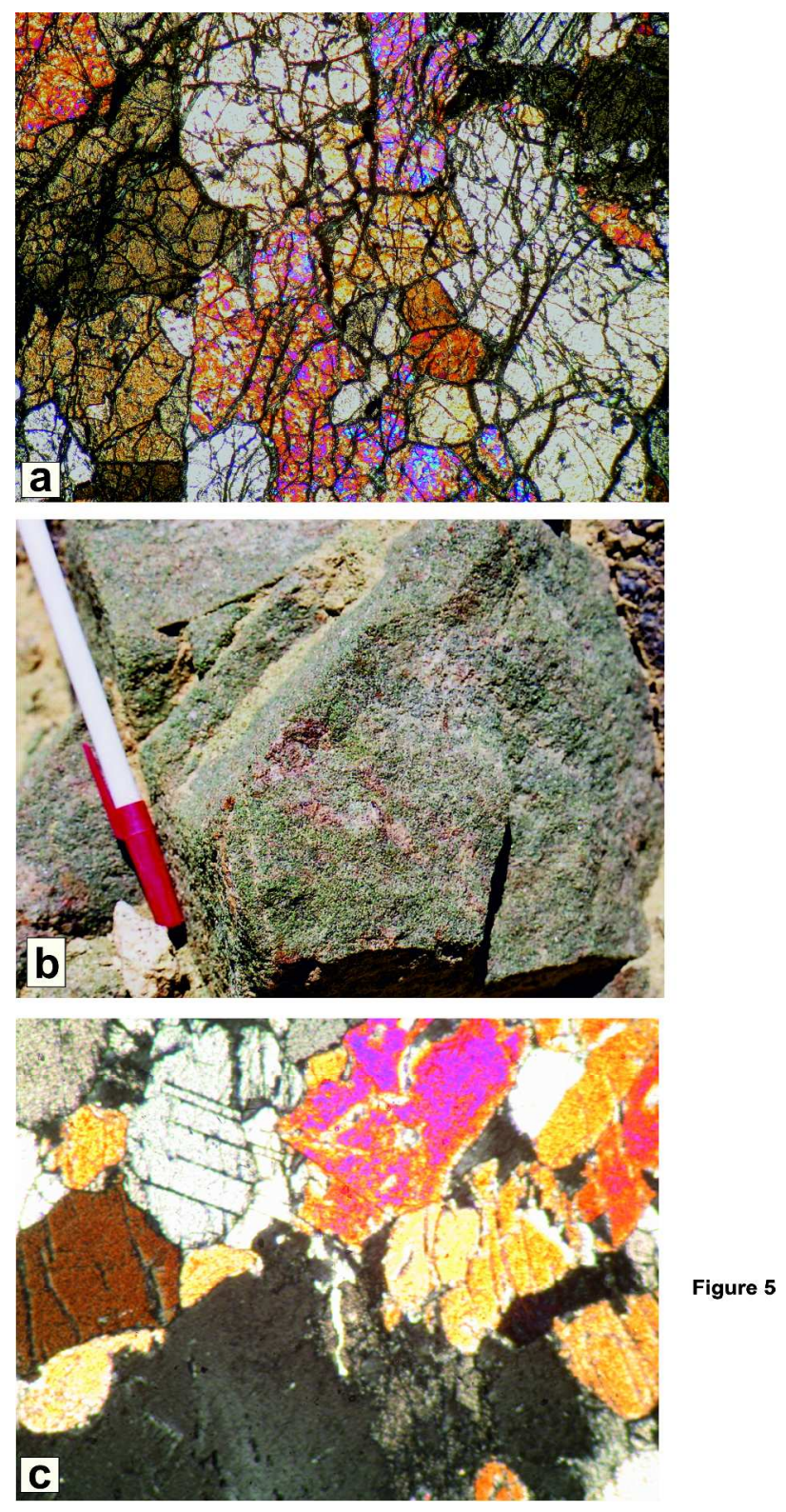

$293 \times 574 \mathrm{~mm}(300 \times 300$ DPI $)$ 

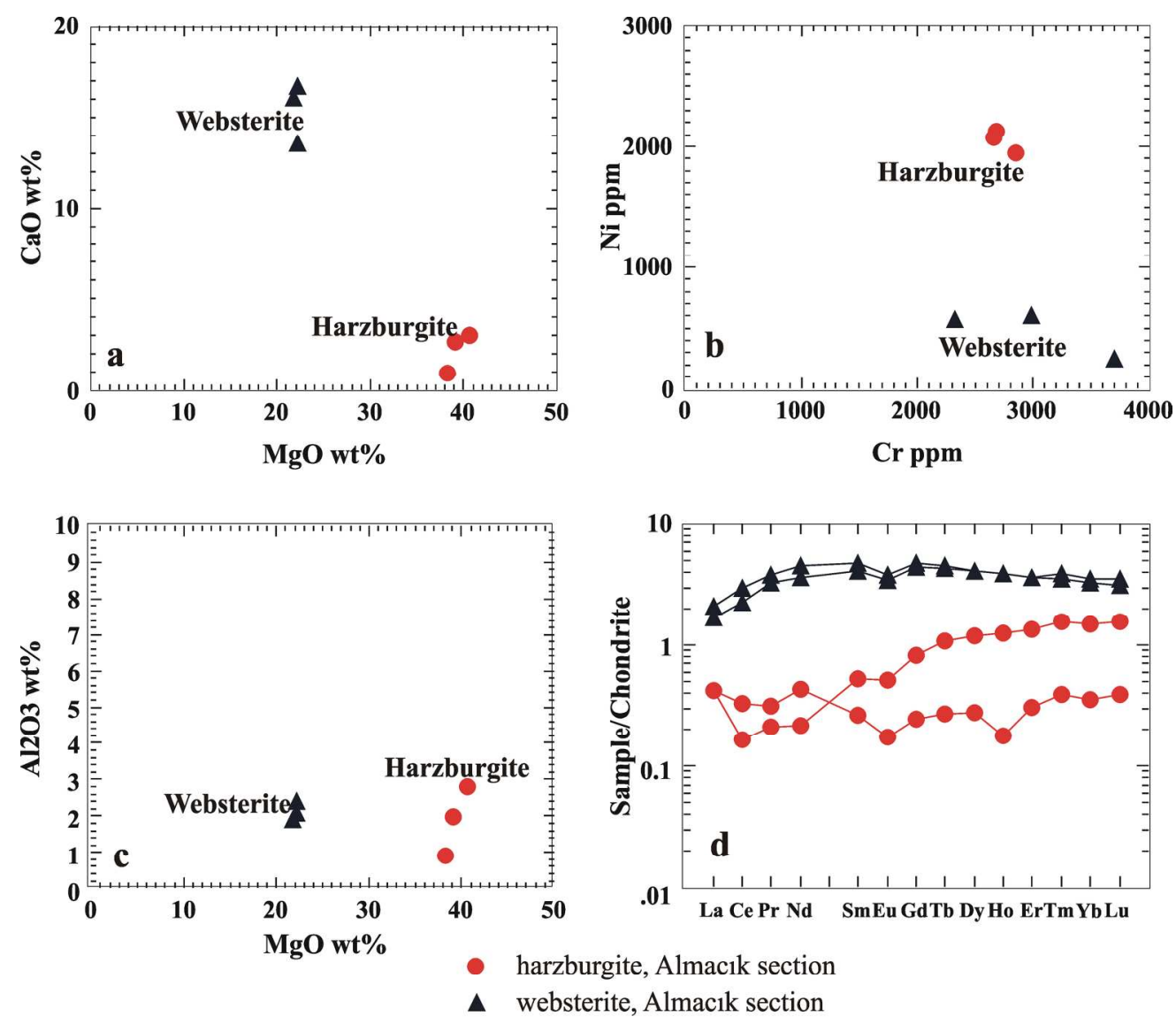

Figure 6

$182 \times 188 \mathrm{~mm}(300 \times 300 \mathrm{DPI})$ 

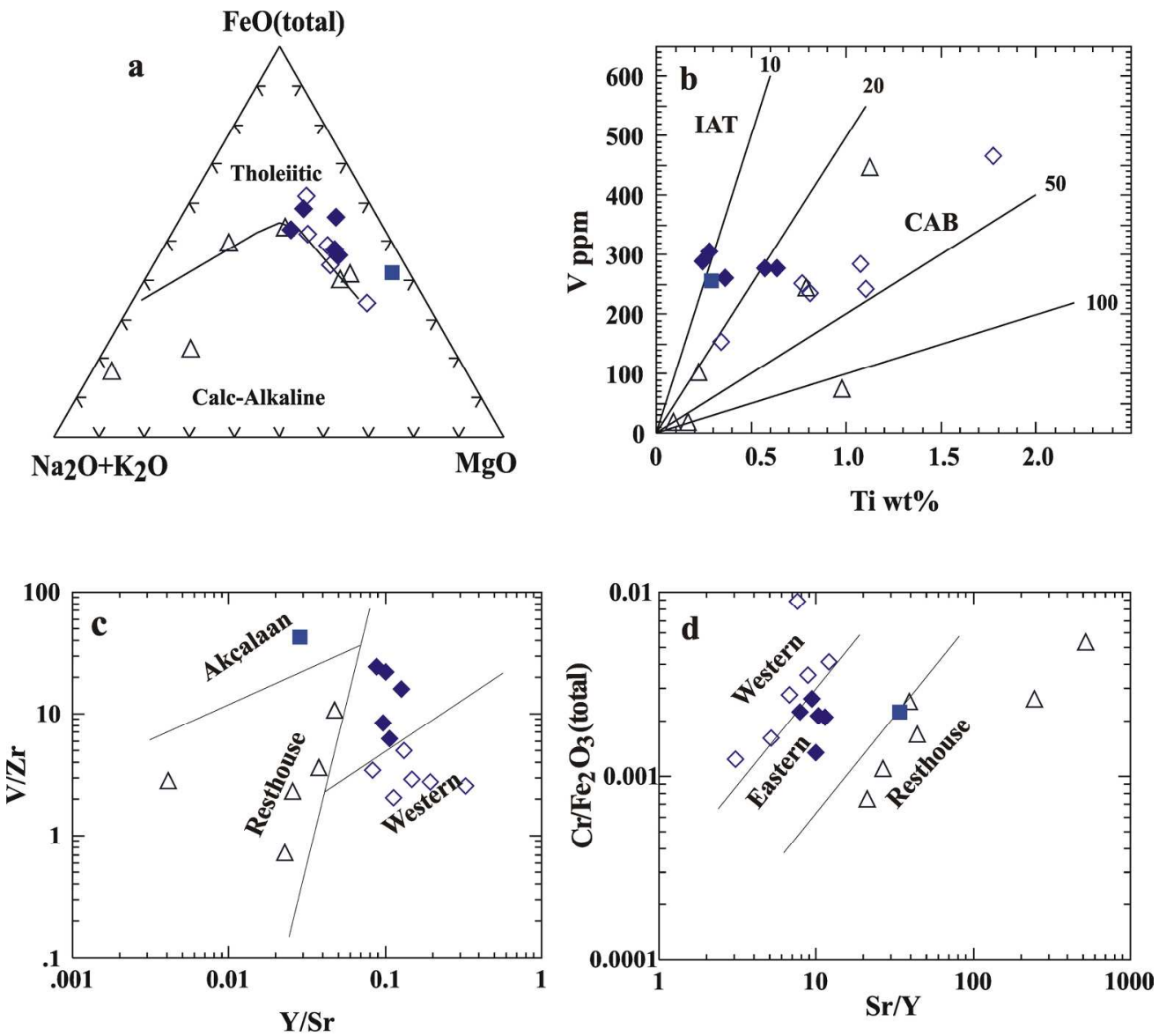

Figure 7

$196 \times 203 \mathrm{~mm}(300 \times 300$ DPI $)$ 

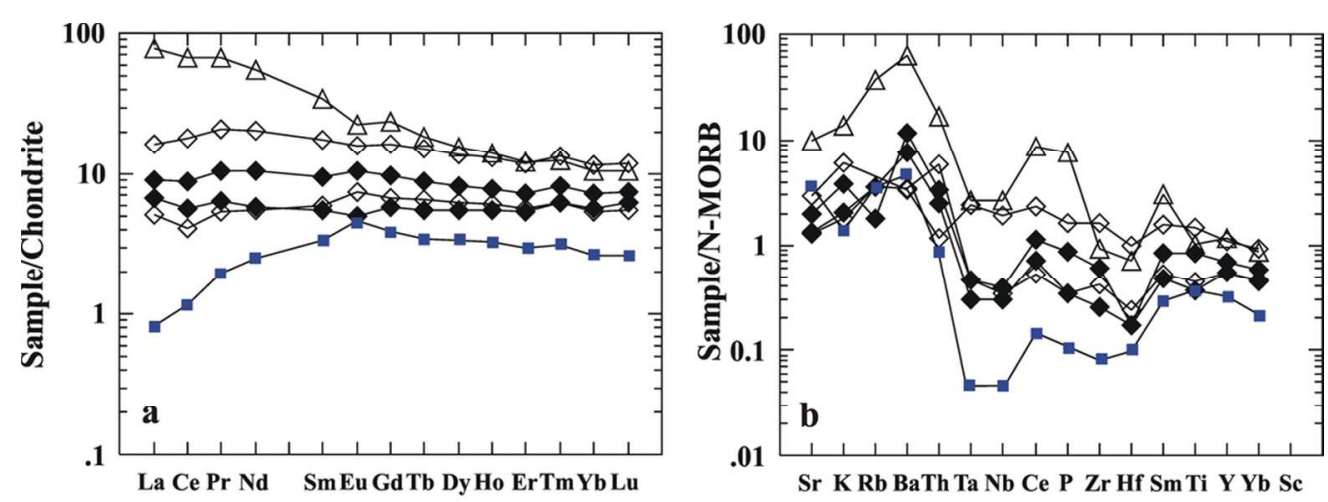

Figure 8

$97 \times 48 \mathrm{~mm}(300 \times 300$ DPI $)$ 

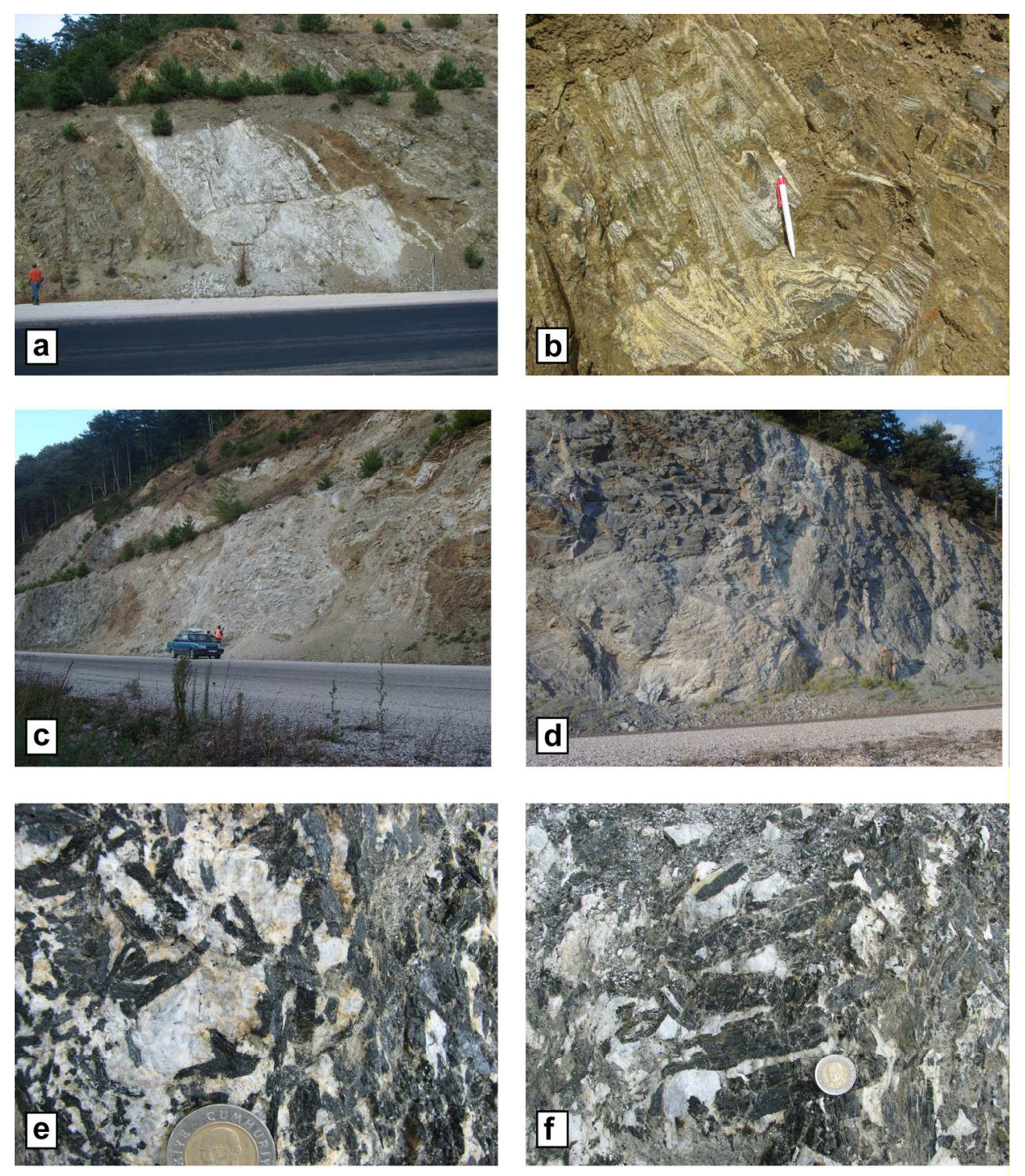

Figure 9

$193 \times 247 \mathrm{~mm}(300 \times 300 \mathrm{DPI})$ 


\section{Page 55 of 56}
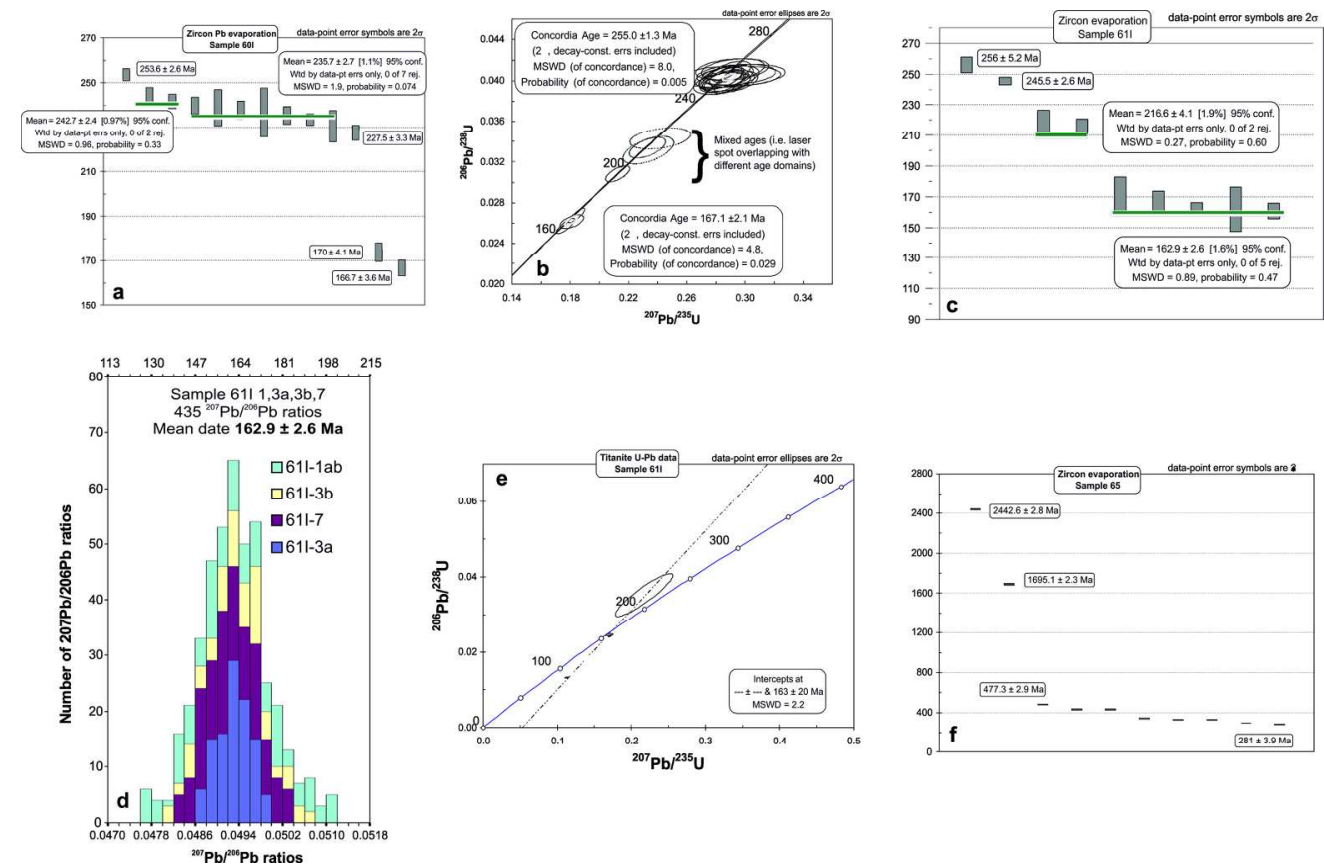

$187 \times 122 \mathrm{~mm}(300 \times 300 \mathrm{DPI})$ 


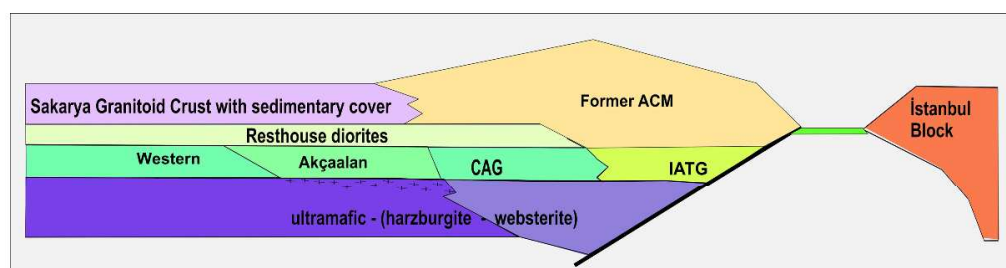

(a) Triassic pre-collisional configuration.

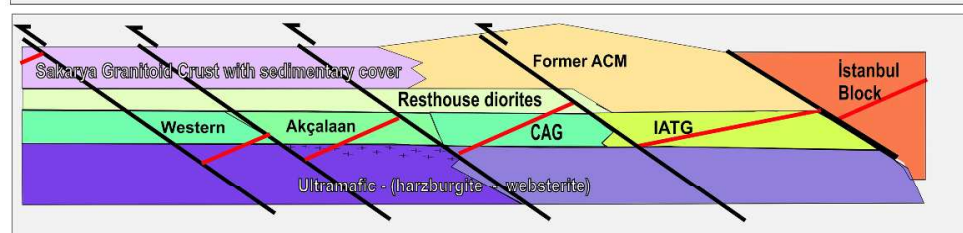

(b) Jurassic syn-collisional configuration, with future thrusting locations indicated. Red lines indicate segments of the Almacık road section
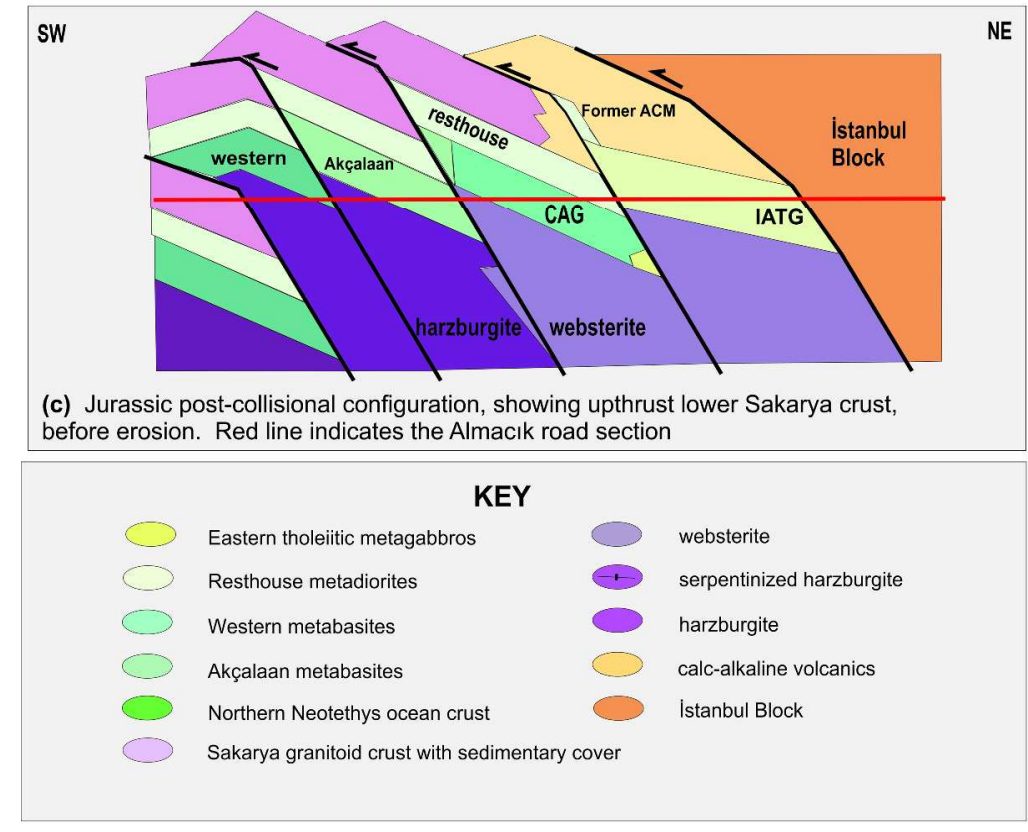

Figure 11 